

\title{
We Need to Talk about Lumbar Total Disc Replacement
}

\section{STEPHEN BEATTY}

Int J Spine Surg 2018, 12 (2) 201-240

doi: https://doi.org/10.14444/5029

http://ijssurgery.com/content/12/2/201

This information is current as of April 26, 2023.

Email Alerts Receive free email-alerts when new articles cite this article. Sign up at: http://ijssurgery.com/alerts 


\title{
We Need to Talk about Lumbar Total Disc Replacement
}

\author{
STEPHEN BEATTY, MD \\ Institute of Health Sciences, Waterford Institute of Technology, Waterford, Republic of Ireland
}

\begin{abstract}
Background: Replacement of a diseased lumbar intervertebral disc with an artificial device, a procedure known as lumbar total disc replacement (LTDR), has been practiced since the 1980s.

Methods: Comprehensive review of published literature germane to LTDR, but comment is restricted to highquality evidence reporting implantation of lumbar artificial discs that have been commercially available for at least 15 years at the time of writing and which continue to be commercially available.

Results: LTDR is shown to be a noninferior (and sometimes superior) alternative to lumbar fusion in patients with discogenic low back pain and/or radicular pain attributable to lumbar disc degenerative disease (LDDD). Further, LTDR is a motion-preserving procedure, and evidence is emerging that it may also result in risk reduction for subsequent development and/or progression of adjacent segment disease.

Conclusions: In spite of the substantial logistical challenges to the safe introduction of LTDR to a health care facility, the procedure continues to gain acceptance, albeit slowly.

Clinical Relevance: Patients with LDDD who are considering an offer of spinal surgery can only provide valid and informed consent if they have been made aware of all reasonable surgical and nonsurgical options that may benefit them. Accordingly, and in those cases in which LTDR may have a role to play, patients under consideration for other forms of spinal surgery should be informed that this valid procedure exists.
\end{abstract}

TDR

Keywords: lumbar artificial disc replacement, lumbar total disc replacement, lumbar disc arthroplasty, lumbar disc degenerative disease, lumbar fusion, lumbar discectomy, informed consent

\section{INTRODUCTION}

The most satisfactory definition for lumbar degenerative disc disease (LDDD) is "a condition where a damaged lumbar vertebral disc causes chronic pain in the lumbar region and/or leg (sciatica)," and the underlying disc changes include annular fissure, degeneration of the nucleus pulposus, and herniation. ${ }^{1}$ Annular fissures (AFs) are separations of annular fibers from their attachment to the vertebral bone and are classed as concentric, radial, or transverse. ${ }^{1}$ Nuclear degeneration (ND) manifests in a wide array of changes, including (but not restricted to) desiccation, fibrosis, and narrowing of the disc space. ${ }^{2-5} \mathrm{~A}$ disc is described as herniated if there is localized displacement of disc material beyond the limits of the intervertebral disc space, and disc herniation $(\mathrm{DH})$ is classified as protrusion or extrusion. ${ }^{1}$ Of note, the presence of disc tissue extending beyond the edges of the ring apophyses, throughout the circumference of the disc, is referred to as bulging and is not considered a form of herniation. ${ }^{6}$ It is important to appreciate that AFs, ND, and $\mathrm{DH}$ are radiologically evident in $39 \%$ to $76 \%, 48 \%$ to $85 \%$, and $27 \%$ to $67 \%$ of asymptomatic patients, respectively. ${ }^{7}$

LDDD can present with low back pain (LBP), sciatica, or both. LBP attributable to LDDD is described as discogenic, is principally midline and immediate paraspinous in the lumbar area, and is aggravated by sitting and flexion. ${ }^{8}$ Discogenic back pain is primarily mechanical in nature and is the result of internal disruption (ND and AFs), leading to the inability of the nucleus pulposus to properly bear the compression load and consequential and inappropriate diversion of this load to the posterior annulus. ${ }^{9-11}$ However, there may also be a chemical component to discogenic LBP, as inflammatory agents contained in degraded matrix materials can stimulate and facilitate nociception. ${ }^{12}$

The term sciatica (or lumbar radiculopathy) refers to pain that radiates from the buttock down along the course of the sciatic nerve, ${ }^{13}$ and neuroradiologic studies report that $87 \%$ of cases are associated with lumbar $\mathrm{DH},{ }^{14}$ the remainder 
being either of extraspinal or of unknown origin. ${ }^{15}$ The sciatic nerve is the largest nerve in the human body, ${ }^{16}$ and disturbances anywhere along its course can give rise to symptoms; in the case of $\mathrm{DH}$, mechanical compression (distortion) of the nerve root below the affected disk is the putative cause, ${ }^{16}$ although the chemical impact of inflammatory cytokines may also contribute to symptoms. ${ }^{17}$ Sciatica attributable to DH is typically aggravated by any Valsalva maneuver and is not always accompanied by LBP. ${ }^{16}$ Weakness and muscle wasting of the affected limb is seen in less than half of cases, and foot drop is rare, ${ }^{16}$ reflecting the view that sensory fibers of the sciatic nerve may be more sensitive to compression than its motor fibers ${ }^{18}$ because the dorsal roots of spinal nerves that subserve nociception are unmyelinated and of small diameter ( $\mathrm{C}$ group peripheral nerves), whereas motor function is subserved by fibers that are myelinated and of large diameter (A group peripheral nerves). ${ }^{19}$ Most clinical tests devised to ascertain whether the reported sciatica is attributable to lumbar $\mathrm{DH}$ are a variation of the straight-leg raising test, which is sensitive $(90 \%)$ but not specific. ${ }^{20} \mathrm{~A}$ few days after the onset of symptoms, electromyography and nerve conduction studies reveal a topographic distribution of muscular denervation corresponding to a nerve root, thereby confirming a radiculopathy. ${ }^{16}$

In the majority of cases, sciatica resolves spontaneously within 3 months of onset. ${ }^{16,21}$ Recovery may be facilitated with physical therapy aimed at enhancing control of the transversus abdominis and multifidus muscles, thereby stabilizing the spine, although the value of such regimes is difficult to measure. ${ }^{16}$ Epidural injections of glucocorticoids are associated with short-term decrease in leg pain but not with a decrease in need for subsequent surgery. ${ }^{22-24}$ Attempts to identify clinical and psychological variables of prognostic value in patients with sciatica have been unrewarding. ${ }^{25}$ For example, of four studies considering the predictive value of duration of symptoms, only one $^{21}$ reported a longer duration to be associated with a poor outcome in cases of conservatively treated sciatica. ${ }^{25}$ Notwithstanding the favorable natural history of symptoms in most cases, a substantial proportion of patients with recalcitrant and disabling sciatica are offered spinal surgery with a view to more effectively and more rapidly alleviating symptoms, ${ }^{26}$ and this approach is rea- sonably premised on the observation that only surgery has been shown to benefit pain relief and a composite of condition-specific outcomes in the short, medium, and long term. ${ }^{27,28}$ Nevertheless, it should be acknowledged that many patients will continue to experience mild to moderate symptoms 5 years after surgery. ${ }^{29}$

In the absence of $\mathrm{DH}$, it is difficult to comment on the natural history of LDDD because of the lack of correlation between evident disease and symptoms, ${ }^{30-32}$ with the inevitable consequence that prospective studies are limited to a subgroup of symptomatic patients. Furthermore, LDDD and its progression are not a mere function of age, because genetic background ${ }^{33-35}$ and environmental factors (ie, mechanical, such as compressive loading, shear stress, and vibration) $)^{12}$ profoundly influence the risk for the condition and its progression, and any correlation is further confounded by the observation that the presence of LDDD at a given level appears to be self-initiating and self-propagating at the same ${ }^{36-38}$ and at adjacent ${ }^{39}$ levels. Notwithstanding the imperfect association between age and LDDD, a relationship does exist, ${ }^{40}$ reflected in and attributable to an age-related decline in the water ${ }^{41,42}$ and macromolecule ${ }^{43}$ content of intervertebral discs; accordingly, LDDD should be viewed as a chronic and progressive condition.

Disc herniation is the result of ND in the presence of $\mathrm{AF}^{44}$ and sciatica attributable to $\mathrm{DH}$ can improve substantially with a nonsurgical approach, resulting in a good or excellent outcome in $85 \%$ to $90 \%$ of cases. ${ }^{45-47}$ Indeed, a recent and systematic review reports that magnetic resonance imaging-confirmed spontaneous regression of lumbar DH occurs in $96 \%, 79 \%$, and $41 \%$ of sequestered, extruded, and protruded cases, respectively. ${ }^{48}$ However, the relationship between clinical improvement and radiologic evidence of spontaneous resorption of herniated disc material is less clear. $^{47}$

Beyond the self-initiating and self-propagating nature of LDDD at the same and adjacent levels, LDDD also appears to cause vertebral body changes $^{49}$ and osteoarthritis of the facet joints. ${ }^{50}$ Furthermore, nerve root enhancement on contrastenhanced magnetic resonance imaging, indicative of peridural fibrosis, ${ }^{51,52}$ is evident in many unoperated cases of disc herniation, ${ }^{53-56}$ but the prognostic value of this finding is doubtful. ${ }^{25,57,58}$ 


\section{SURGICAL OPTION IN PATIENTS WITH LUMBAR DISC DEGENERATIVE DISEASE}

Appropriately selected patients are offered surgery in cases of LDDD, and there are three surgical approaches available: 1) disectomy, 2) fusion procedures, and 3) lumbar total disc replacement.

\section{Discectomy}

Discectomy, including microdiscectomy, endoscopic microdiscectomy, and laminectomy/laminotomy with discectomy, is offered to patients with lumbar DH with severe and persistent sciatica and/ or neurological sequelae, and it is aimed at relieving nerve root compression or irritation caused by herniated disc material. ${ }^{59}$ In an analysis of 30809 patients who had undergone this procedure for this surgical indication, $78 \%$ reported good/excellent results at a mean follow-up of 6.1 years. ${ }^{60}$ However, 1 large trial $(n=283)$ with low risk of bias revealed that although surgery did result in faster pain relief when compared with prolonged conservative treatment in patients who were symptomatic for 6 to 12 weeks, there was no difference after 1 year. ${ }^{61}$ Although these findings were consistent with the 2year results of the Spine Patient Outcomes Research Trial (SPORT; $\mathrm{n}=501$ ), ${ }^{62}$ the 8 -year results did report that surgery (in this case, open discectomy) was superior to nonoperative treatment in relieving symptoms and improving function. ${ }^{63}$ However, the impact, positive or adverse, of discectomy on the natural course of LDDD remains unclear. ${ }^{64}$ Further, repeat discectomy in cases of recurrent lumbar DH is less successful than primary discectomy in unoperated patients with lumbar $\mathrm{DH},{ }^{57}$ especially if there is evidence of epidural fibrosis in the operative field. ${ }^{65}$

\section{Fusion Procedures}

Fusion (arthrodesis) may be indicated in cases of discogenic pain caused by LDDD or in cases in which recurrent $\mathrm{DH}$ is causing mechanical back pain or sciatica; it is premised on the rationale that it reduces the nociceptive load by wide removal of the disrupted disc material and the stabilization of the affected motion disc segment(s). ${ }^{66}$ The value of lumbar spine fusion for discogenic low back pain in cases of LDDD remains controversial and contested, with some reviews and meta-analyses being unable to conclude that surgery is superior to the conservative approach, ${ }^{67}$ whereas others advocate the procedure. ${ }^{68}$ In cases of recurrent disc herniations, there is little evidence in support of lumbar fusion for patients with evidence of instability or chronic LBP. ${ }^{69}$ Although argument continues with respect to the quantification of risk of adjacent segment disease (ASD) following lumbar fusion, there is a consensus that this procedure is indeed associated with increased risk of pathology of adjacent segments. $^{70}$

\section{LUMBAR TOTAL DISC REPLACEMENT}

\section{Premise and Rationale}

The intervertebral disc is an avascular structure, the principle function of which is to confer limited mobility on the spine and to act as a shock absorber. Lumbar total disc replacement (LTDR), which involves removing the patient's disc and replacing it with a lumbar artificial disc (LAD), was developed with a view to avoiding undesirable sequelae of lumbar arthrodesis (principally, motion sacrifice and ASD, but also a plethora of other fusionrelated complications). ${ }^{71}$ Put simply, the objective of LTDR is to remove the diseased disc that is causing pain while minimizing the risk of ASD and restoring normal motion in the postoperative patient (by sparing the physiological motion, maintaining an ideal sagittal balance, and stabilizing the lumbar spine in good curvature).

In brief, the rationale for LTDR is sound.

\section{History}

\section{0-1988}

The first LAD, consisting of a steel ball, was implanted in 1960, and the procedure was ultimately complicated by late postoperative subsidence. ${ }^{72}$ Throughout the 1980s, small, observational (uncontrolled) series of LTDRs using the SB Charite LAD reported encouraging outcomes. ${ }^{73-77}$ During this period, there were a total of 4 publications on the subject of $\operatorname{LTDR}^{72-74,77}$; of these, only the first case report was published in the English language. ${ }^{72}$

\section{9-1998}

In 1990, Marnay implanted the first ProDisc I model of $\mathrm{LAD}^{71}{ }^{71}$ and this design was subject to successive refinements, culminating in the launch of the ProDisc II in 1999. ${ }^{78}$ Throughout the 1990s, using either an SB Charite model ${ }^{79-83}$ or a ProDisc (I and/or II), ${ }^{78,84}$ small and observational (uncon- 
trolled) series of LTDRs continued to indicate successful outcomes; however, poor results were reported following implantation of an alternative design. ${ }^{85}$ In this period, there were 6 peer-reviewed articles reporting surgical outcomes, ${ }^{79-83,85} 1$ clinical review, ${ }^{76}$ and 4 nonclinical biomechanical reports on the subject of LTDR. ${ }^{86-88}$

\section{9-2008}

The encouraging results at the end of the 1990s, albeit emanating from low-level evidence, went some way toward providing proof of principle in the concept of LTDR. As a consequence, uptake of the procedure by spinal surgeons (and investment by medical device companies in innovation in LAD design) flourished, reflected in 102 peer-reviewed articles reporting surgical outcomes, ${ }^{78,89-189} 63$ clinical reviews (including correspondence to journals), ${ }^{190-252} 46$ nonclinical biomaterial and biomechanical reports, ${ }^{253-298}$ and the advent of 5 new LADs $^{99,118,165,176,299,300}$ to the market between 1999 and 2008.

\section{9-2017}

In spite of its complex and technically demanding nature, and because of the promising short- and mid-term results, spinal surgical centers continue to adopt LTDR, but slowly. Indeed, between 2009 and the time of writing (November 2017), a steady growth of the peer-reviewed literature on the subject of LTDR is reflected in a further 178 peer-reviewed articles reporting surgical outcomes, ${ }^{301-479} 110$ clinical reviews (including correspondence to journals), ${ }^{66,398,480-558} 94$ nonclinical biomaterial and biomechanical reports, ${ }^{*}$ and the advent of 10 new LADs. ${ }^{\dagger}$

\section{LADS: BIOMECHANICAL AND BIOMATERIAL CONSIDERATIONS}

Given that meaningful discussion is predicated on meaningful research and its clinical applicability, reported herein are outcomes following implantation of only those LADs that have been and remain commercially available for at least 15 years at the time of writing and that have been investigated by Level 1 evidence (systematic review of randomized controlled trials [RCTs; Level 1a] or an individual RCT with a narrow confidence interval [Level

*References 284, 319, 348, 377, 559-649.

$\uparrow$ References 306, 313, 318, 324, 391, 402, 441, 562, 582, 643, 650. 1b] $)^{651}$ and have a minimum follow-up of five years. Devices not meeting these criteria are not systematically reviewed but, where relevant, will be discussed where their use has yielded insights into the challenges inherent in LTDR.

In order to be effective, a prosthetic intervertebral disc must have a solid nondestructive interface with the adjacent vertebral bodies, provide mobility, and resist wear. ${ }^{648}$ LADs may be classed as articulating or nonarticulating, the former relying on a mechanical interface and the latter consisting of a deformable elastomeric core. ${ }^{629}$

\section{Articulating LADs}

Typically, articulating LADS are classed according to back motion limitation in mobility and are therefore described as nonconstrained or semiconstrained. ${ }^{71}$ A nonconstrained LAD has no specific limitation in its mobility, whereas a semiconstrained LAD may allow partial translation or no translation. The more constrained an LAD, the greater the risk of adverse sequelae following less-than-perfect primary placement of the device ${ }^{75}$; the less constrained an LAD, the greater the mechanical stresses imposed on the posterior joints. ${ }^{94}$

The ProDisc-L (Synthes Spine, West Chester, Pennsylvania) is the only LAD to fulfill our aforementioned and a priori criteria for critique $^{341,343}$; this LAD is of a semiconstrained design that prevents pure translation, the latter restriction aimed at protecting the facets from excessive shear loading. ${ }^{94}$ The device is based on a ball-and-socket principle and consists of two cobalt chrome alloy endplates and an ultra-high-molecular-weight polyethylene (UHMWPE) inlay; the endplates have central keels and small spikes for initial fixation on the vertebral bodies. ${ }^{135}$

\section{Nonarticulating LADs}

The failure of articulating LADs to replicate the elasticity of the native disc has prompted the development of compressible yet nonarticulating devices aimed at more closely emulating the shock absorptive and flexural stiffness properties of the natural nondiseased intervertebral disc. ${ }^{629}$ Challenges inherent in the development of such devices include the identification of materials that are biocompatible (given that the potential for periprosthetic tissue reaction would presumably be increased because such reactions relate to the number of particles generated ${ }^{649}$ ), that are resistant 
to wear and tear(s), and that provide sufficient adhesion to the vertebral bodies. ${ }^{402}$ In any case, our aforementioned and a priori criteria for meaningful comment preclude such LADs being reviewed here. ${ }^{629}$

\section{Clinical Outcomes}

The first LAD to be used on a large scale was the SB Charite (DePuy, Inc, Raynham, Massachusetts), and there is ample Level 1 evidence of its implantation resulting in superior ${ }^{108,129,155,416}$ or noninferiort outcomes when compared with fusion in cases of LDDD, whereas there is no published Level 1 evidence of LTDR being inferior to its lumbar interbody fusion (LIF) comparator using this LAD. Studies (typically observational) representing lesser levels of evidence have also reported favorable outcomes of LTDR using this LAD. $\S$ Series|| and case reports ${ }^{97,112,149,161,409,456}$ of adverse events in association with use of the SB Charite are also plentiful. By 2007, more than 15000 Charite LADs had been implanted. ${ }^{161}$ In 2009, DePuy merged with Synthes (the manufacturer of ProDisc-L), whereupon the new entity (DePuy Synthes, part of the Johnson \& Johnson Family of Companies) discontinued the SB Charite LAD in favor of the ProDisc-L LAD (see below).

Indeed, and for a range of LADs, there is a growing body of Level 1 evidence demonstrating superiority\# or noninferiority $498,503,529,544,553$ of LTDR when compared with fusion in the management of LDDD (with follow-up ranging from 1 to 4 years), whereas no comparative studies/meta-analyses conclude in favor of fusion over LTDR. Beyond comparisons between LIF and LTDR, many favorable (typically observational) reports of LTDR using a variety of LADs, but representing lower levels of evidence and/or a follow-up of less than 5 years, have also been published.** Poor outcomes

$\$$ References $102,103,151,154,175,418$.

§References 98, 123, 141, 143, 160, 163, 170, 177, 179-181, 312, 386, 464.

||References 113, 115, 121, 126, 128, 138, 157, 172, 173, 319, 322, 345 , $387,392,400,410,414,443,450,460$.

\#References 78, 251, 306, 327, 375, 406, 408, 453, 485, 492, 504.

**References 79-83, 95, 99, 100, 106, 111, 117, 120, 127, 133-135, $139,144,145,147,148,152,153,156,158,159,165,166,178,182$, $183,187,301,305,308-311,313-315,317,318,321,323,324,326$, $329,331,335,347,349,352,353,356,358-362,364,367-370,372$, $373,381-384,388-391,393,394,402,405-408,411-413,417,420$, $422-428,430-432,436-438,440-442,444,446,449,452,454,455$, $459,460,465,467,469,471,475$.

$\dagger$ Teferences 328, 344, 365, 439, 447, 448, 465. have also been published, ${ }^{334}$ as have case reports $\dagger^{\dagger} \dagger$ and seriestt of adverse events following implantation of these various LADs.

There has been (to our knowledge) only 1 study comparing outcomes following LTDR with outcomes following conservative rehabilitative therapy, in which 173 patients with LBP attributable to LDDD (of note, radicular pain was an exclusion criterion) were randomized to surgery (using the ProDisc II; $\mathrm{n}=86$ ) or to a nonsurgical approach consisting of supervised physical exercise in combination with cognitive support $(n=87) .{ }^{461,652}$ Although the prespecified minimally important clinical differences were not achieved at 2 years, LBP and physical disability did exhibit a significantly greater improvement (reflected in the Oswestry score) among patients who had undergone LTDR than among patients managed conservatively. ${ }^{437,461}$ At 8 years' follow-up, the findings continued to favor surgery over multidisciplinary rehabiliation. ${ }^{468}$

In an attempt to ensure clinical relevance and validity, and in keeping with the a priori criteria (ie, attention directed toward LTDR following implantation of $\mathrm{LAD}[\mathrm{s}]$ that have been investigated through high-quality evidence and that have been [and remain] commercially available for at least fifteen years at the time of writing, thereby facilitating comment on long-term sequelae of this procedure using a given device), a discussion largely restricted to LTDR using the ProDisc-L now ensues.

A prospective, randomized, multicenter US Food and Drug Administration (FDA) investigational device exemption (IDE) study compared outcomes following LTDR using the ProDisc-L $(n=161)$ with outcomes following circumferential fusion (control group, $\mathrm{n}=75$ ) for the treatment of back and/or radicular pain attributable to 1-level LDDD. At 2 years, the LTDR group fared significantly better than the control group in terms of the Oswestry Disability Index, visual analogue pain assessment, patient satisfaction, and FDA-defined overall success; furthermore, radiographic flexionextension range of movement (ROM) analysis revealed greater motion at 24 months than preoperatively in $89 \%$ of patients who had undergone LTDR. ${ }^{119}$ This was also the case for patients who had undergone 2-level LTDR. ${ }^{376}$ The observed superiority of LTDR over fusion was demonstrated in spite of the investigation not being designed to

\$References $118,330,354,380,419,421,460$. 
show a difference between the surgical techniques (ie, the study was only powered to demonstrate/ refute noninferiority of LTDR when compared with the surgical standard of care [fusion]). At 5 years, observed improvements in outcome measures were maintained, the segmental ROM remained within the normal range following LTDR, and secondary surgical procedures had been required at the index level in $8 \%$ and $12 \%$ of LTDR and fusion patients, respectively. ${ }^{343}$ Moreover, incidence of adjacentlevel degeneration was evident in a significantly lower proportion of patients following LTDR $(6.7 \%)$ than following fusion $(23.8 \%),{ }^{341}$ and outcomes were comparable for patients who had undergone 1-level or 2-level LTDR. ${ }^{332}$

Since publication of that RCT, amelioration of symptoms and improvements in Oswestry Disability Index have consistently been reported in prospective studies of LTDR using the ProDisc-L investigating outcomes (and variables that might influence those outcomes), and examples include the following: good pain relief and functional improvement in the absence of device-related complications $(n=104$; minimum follow-up of 2 years) ${ }^{139}$; demonstrable pain relief following the procedure at 2 years' follow-up, with some regression at 5 years' followup (but remaining significantly improved from preoperative pain levels; $\mathrm{n}=36$; minimum followup of 5 years) ${ }^{369}$; use of this procedure to treat symptomatic ASD following remote fusion $(n=20$; minimum follow-up of 2 years ${ }^{92}$; outcomes not adversely impacted by smoking $(n=104$; minimum follow-up of 2 years; $)^{91}$; outcomes not adversely affected by patient age greater than 60 years $(\mathrm{n}=22 \text {; minimum follow-up of } 2 \text { years })^{93}$; successful outcomes achieved following bisegmental and trisegmental implantation of this LAD $(n=25$; minimum follow-up of 2 years $)^{94}$; improvement of physical capability following the procedure $(n=18$; minimum follow-up of 1 year $)^{358}$; results at 18 months' follow-up that were excellent $(\mathrm{n}=11 ; 61 \%)$ or good $(\mathrm{n}=3 ; 16 \%)$ in 14 of 18 patients $(77 \%)$ and results at 6.5 years' follow-up that were excellent $(\mathrm{n}=10 ; 55 \%)$ or $\operatorname{good}(\mathrm{n}=2 ; 11 \%)$ in 12 of 18 patients $(66 \%){ }^{364}$

With respect to the consequences of LTDR for sagittal balance and lumbar spine movement following LTDR (using 1 of 3 models of LAD, including the ProDisc- $\mathrm{L}[\mathrm{n}=10]$, and where the device was confirmed radiologically to be centered), the following observations were made: an increase in disc height; no significant change in range of motion at the index level; no impact on pelvic incidence, pelvic tilt, or sacral slope; and an increase in L1-S1 lordosis (although 94\% of subjects remained in the physiologic range). ${ }^{132}$ In a prospective study of 42 patients who underwent ProDisc-L implantation at either L4-L5 or L5-S1, a mean increase in disc height was observed of $6.8 \mathrm{~mm}$ anteriorly and $3.5 \mathrm{~mm}$ posteriorly, and mean range of movement decreased from $7^{\circ}$ to $5.7^{\circ}$; however, there was a positive relationship between postoperative disc height and ROM, prompting the investigators to suggest that patients with greater preoperative disc collapse are more likely to benefit from LTDR in terms of this outcome measure. ${ }^{164} \mathrm{In}$ a study of 12 patients (15 ProDisc-L LADs), implantation of 4 to 5 tantalum beads into the vertebrae adjacent to the surgical level at the time of surgery enabled radiostereometric analysis and revealed an average ROM at 12 months of $6.3^{\circ}$ and $3^{\circ}$ in the sagittal plane and on lateral bending, respectively; these post-LTDR ROMs, although less than normative values for ROM in these planes, are superior to observed ROMs $\left(0^{\circ}\right.$ to $\left.4^{\circ}\right)$ following fusion. ${ }^{167}$ In another study involving 200 patients (155 undergoing LTDR using the ProDisc-L and 45 undergoing fusion, and followed for at least 24 months), total lumbar ROM increased by $6.3^{\circ}$ in those who had undergone LTDR at the L4-L5 level, and segmental analyses revealed that patients exhibited slight loss of relative contribution to total lumbar motion from the operative level but that this was compensated for by the caudal adjacent level (although no increase in total lumbar ROM was observed following LTDR in patients in whom the LAD was implanted at the L5-S1 level); in contrast, loss of relative ROM contribution from the operative level was observed following fusion (and was redistributed among multiple cranial adjacent levels, but primarily by the first cranial level). ${ }^{406}$ In a prospective study of 40 patients scheduled for monosegmental or bisegmental LTDR using the ProDisc-L (comprising 45 LADs), ${ }^{451}$ absolute segmental ROM and total lumbar ROM was assessed preoperatively and again 3 years postoperatively. No significant change was observed in either of these outcome measures (mean preoperative measures of absolute segmental ROM and total lumbar ROM were $6.9^{\circ}$ and $34.9^{\circ}$, respectively, compared with mean postoperative measures of $7.3^{\circ}$ and $35.8^{\circ}$, respectively; these results reflected an increase, a 
decrease, and no change in the former in $40 \%, 35 \%$, and $25 \%$ of patients, respectively, and an increase, a decrease, and no change in the latter in $40 \%, 30 \%$, and $30 \%$ of patients, respectively), while a compromised clinical outcome was observed in association with decreased total lumbar ROM. Segmental translation (mean $\pm \mathrm{SD}: 0.83 \mathrm{~mm} \pm 0.78 \mathrm{~mm}$ ) at 24 months' follow-up has been demonstrated in a study of 35 LTDR patients in which the ProDisc-L was used, and the observed segmental translation was related to segmental ROM, to global lumbar ROM, and to observed change in the height of the functional spine unit. ${ }^{429}$

Some years ago, the International Society for the Advancement of Spine Surgery (ISASS) selected a panel of physicians and charged that panel with the task of educating patients, physicians, medical providers, reviewers, adjustors, case managers, insurers, and others on the subject of LTDR solely on the basis of best evidence-based scientific research. In 2015, this ISASS panel issued a policy statement concluding that single-level LTDR represents a proven technique and a well-tested technology that must be accepted for the benefit of patients and that single-level LTDR should lead to better outcomes and fewer complications than fusion surgery, with the additional putative benefit of exerting a protective effect on adjacent levels. ${ }^{483}$ With respect to the ProDisc-L, the ISASS panel notes that patients suffering from persistent back pain and/or radicular pain attributable to LDDD are suitable candidates for LTDR using this LAD. $^{483}$

Finally, it should also be noted that there is evidence that patients with LDDD have a greater likelihood of being totally pain free following LTDR (using 1 of 3 LADs, including the ProDiscL) than following fusion. ${ }^{513}$

\section{COMPLICATIONS OF LTDR (USING THE PRODISC-L)}

The complications of LTDR are classed as spinal or nonspinal.

\section{Nonspinal Complications of LTDR}

The nonspinal complications of LTDR are classed as intraoperative (injury to ureter, nerves, ${ }^{378}$ or large vessels ${ }^{71,433}$ ) or postoperative (infection, ${ }^{404}$ retrograde ejaculation, wound problems, hemato$\mathrm{ma}^{71}$ formation of retroperitoneal lymphocele ${ }^{401}$ ) and are common to all LTDR procedures that adopt an anterior lumbar surgical approach, irrespective of the LAD used. Although a less-invasive lateral approach a $^{313,420}$ or a laparoscopic approach $^{430}$ for LTDR may impact the risk of the aforementioned and other complications, these innovations do not fulfill our a priori criteria for meaningful comment.

\section{Spinal Complications of LTDR}

The spinal complications of LTDR are classed as those attributable to LAD malposition or those that can occur in the presence of (persistently) optimal LAD anchorage.

\section{Spinal LTDR Complications Attributable to $L A D$ Malposition}

Malposition of the implanted LAD may be the result of suboptimal placement at the time of the procedure or the result of postoperative migration or subsidence.

Suboptimal Anchorage of the LAD at the Time of Surgery. LTDR is a technically challenging procedure, and it is unsurprising that implantation of the first generation of LADs (the SB Charite) was associated with a steep learning curve, ${ }^{171}$ that suboptimal placement was seen in $60 \%$ of cases, ${ }^{345}$ and that ideal placement of the LAD was associated with better clinical and functional outcomes. ${ }^{345}$ The critical importance of primary anchorage has been reported for other LADs. ${ }^{331,349,458}$

A study of 201 cases with 5-10 years' follow-up in which the ProDisc II (the predecessor of ProDisc-L) was implanted by surgeons who were new to the procedure reported good results. ${ }^{323}$ Nevertheless, in a series of 41 LTDR patients in which the ProDisc II was used, progression of facet degeneration at the index level was seen in $29.3 \%$ of cases and was related to malposition of the LAD on the frontal plane. $^{182}$

With respect to the ProDisc-L, patients who suffered adverse events related to LTDR in an IDE RCT comprising 151 participants were significantly less satisfied than patients who did not suffer such adverse events at 24 months, emphasizing the importance of surgical precision and ease. ${ }^{397}$ In 1 cohort of 44 patients undergoing LTDR using the ProDisc-L, operating time decreased with increasing experience, but ultimate clinical and functional 
outcomes were not compromised by undergoing the procedure with a less-experienced surgeon. ${ }^{436}$

In summary, ideal placement of the ProDisc-L (or any LAD) is a prerequisite for optimal outcomes; accordingly, there is an argument for acknowledged exclusion of cases with less-thanperfect primary anchorage when the rationale and/ or long-term outcomes of LTDR are under investigation but inclusion when the real-world implications of performing this procedure are under investigation.

Migration/Subsidence of the Implanted LAD in the Postoperative Period. In a series of 52 patients who underwent LTDR using the ProDisc II, radiographs were independently analyzed 3 days postoperatively and again between 6 and 24 months postoperatively, and no cases of migration were observed. ${ }^{184}$ However, in a series of 18 patients (19 LADs) in whom removal of a ProDisc- $\mathrm{L}$ was indicated on clinical grounds, migration and endplate subsidence of the prosthesis were evident in $3(15 \%)$ and 4 $(21 \%)$ cases, respectively; further, polyethylene dislodgement was evident in a further $3(15 \%)$ cases. $^{348}$ To our knowledge, however, there are no data on the incidence of LAD migration and subsidence following ideal placement at the time of surgery.

\section{Spinal LTDR Complications Unrelated to $L A D$ Malposition}

Periprosthetic Wear Debris. Beyond device-related problems arising from LAD malposition, biological responses to periprosthetic wear debris can also give rise to spinal complications following LTDR.

The ProDisc-L LAD consists of 2 cobalt-chromium metallic endplates, which are fixed to the adjacent vertebral bodies and which articulate against a core made up of ultra-high-molecularweight polyethylene (UHMWPE); hence, this LAD is classed as metal-on-polyethylene. ${ }^{319}$ However, wear of the UHMWPE core has been observed in several models of metal-on-polyethylene LAD, with consequential and adverse implications for clinical outcomes. ${ }^{319}$ Such periprosthetic tissue reactions were first described in 2009, when polyethylene particles were detected in 15 of 16 tissue samples taken from patients undergoing revision surgery for intractable pain following implantation of the SB Charite LAD (also a metal-on-polyethylene LAD) and the concentration of these particles was positively related to the periprosthetic tissue reaction. ${ }^{414}$ The observed periprosthetic tissue reactions following LTDR (using the SB Charite LAD) are not dissimilar to those observed following total hip replacement and total knee replacement and can occasionally result in osteolyis, subsidence, migration, and fusion. ${ }^{126,172,377,588}$ Of note, severe rim impingement of the implanted LAD is associated with increased production of biologically relevant UHMWPE particles, at least with the SB Charite LAD. ${ }^{572}$

With respect to the ProDisc-L, kinematic studies suggest that the osteolytic potential of wear particles associated with its use is lower than for total hip replacement as a consequence of lower wear rates. ${ }^{568,646}$ However, posterior component impingement is seen in a considerable proportion of patients with ProDisc-L prostheses, especially following L4-L5 and bisegmental implantations, and this may be a risk factor for periprosthetic reactions in some patients. ${ }^{162}$ Although the ProDisc-L has not been associated with numerous reports of adverse clinical outcomes attributable to periprosthetic tissue reaction, 1 series of 8 cases of this LAD being retrieved from seven patients has been reported, in which revision surgery was indicated for recalcitrant back pain (and osteolysis was evident in two cases) and subsequent periprosthetic tissue analysis revealed UHMWPE particles; however, the authors noted a $99 \%$ reduction in the particle numbers when compared with their own earlier studies of retrieved SB Charite LADs and concluded that wear resistance of contemporaneous LADs has improved greatly when compared with historical LADs. ${ }^{319}$

Concerns Germane to Facet Arthrosis. LTDR necessarily compromises the anterior longitudinal ligament and the annulus fibrosus (and sometimes the posterior longitudinal ligament), giving rise to concerns regarding the possibility of rotational instability. ${ }^{443}$ One 10 - to 14 -year follow-up of 5 patients implanted with the SB Charite at one level revealed mobility in torsion identical to that of 6 volunteers (although normal kinematics were not restored in patients who had undergone bisegmental LTDR), ${ }^{136}$ indicating that compensatory and active stabilizing elements play a beneficial role in vivo (thereby explaining the disparity with in vitro predictions from cadaveric studies ${ }^{607}$ and finite models ${ }^{623}$ ). Indeed, it appears from a series of 10 
patients who underwent LTDR that the most important determinant of postoperative index-level and adjacent-level vertebral rotation in the sagittal plane is, in fact, preoperative $\mathrm{ROM},{ }^{305}$ and this observation represents an unappreciated confounding factor for interpretation of nonclinical biomechanical and kinematic studies germane to this procedure.

Concerns regarding spinal instability following LTDR have profound implications for the facet joints of the posterior spine, which are true synovial joints found at every spinal level (except C1-C2) and which represent 2 of the 3 articulations between adjacent vertebrae, the third articulation being the intervertebral disc. ${ }^{653}$ Accordingly, the total motion of the spine is a composite of the motion of the individual motion segments (or " 3 -joint complexes"), and the purpose of the bilateral facet joints (together with the disc) is to transfer loads and guide and constrain motions in the spine ${ }^{534}$; in this latter regard, and more specifically, an important function of the facet joints is to aid in the inhibition of rotation and excess motion in order to keep the vertebrae aligned. ${ }^{648}$ In most cases, the disc is the primary load-bearing structure of any given motion segment, carrying up to $33 \%$ of total load borne by that segment, and this load is increased and decreased during spinal extension and flexion, respectively. ${ }^{654}$ In cases of narrowed and functionally incompetent intervertebral discs, less body weight is supported by the disc and forces are consequentially transmitted across the facet joints, ${ }^{654}$ reflected in the observation that up to $70 \%$ of an axial load can be borne by the facet joints in cases of severe LDDD (thus predisposing to facet arthrosis). ${ }^{655}$

Biomechanical studies have suggested that LTDR using ball-and-socket-type LADs (such as the ProDisc-L) results in increased facet loading at the surgical level, ${ }^{624}$ especially following L4-L5 and L5S1 LAD implantation, ${ }^{590}$ and these observed increases in facet loading are more evident during lateral bending and axial rotation; and that posterior placement of the prosthesis provides a more physiologic load transfer to the vertebral body. ${ }^{294,584,634}$ Although such devices may also increase ROM under axial load, they seem to maintain the helical axis of motion with similar facet contact forces to the intact spine. ${ }^{635,637}$ Moreover, the degree of LAD constraint affects postimplantation kinematics and load transfer, such that a semiconstrained LAD (eg, ProDisc II, ProDisc-L, Maverick) results in the facets being partially unloaded when compared with unconstrained LADs (such as the SB Charite) ${ }^{253}$ Further, a small study comparing paradoxical and coupled motions following LTDR (using the ProDisc-L; $\mathrm{n}=10)$ and lumbar discectomy $(\mathrm{n}=8)$ revealed similar postoperative overall sagittal ROM and coupled motion for the 2 procedures, but significantly greater paradoxical motion was seen at the L4-L5 level ${ }^{109}$ (with possible adverse implication for facet degeneration) following LTDR. ${ }^{147}$ Ultimately, in situ function of the ProDisc-L will be determined by how well it is incorporated into the mechanical environment within the disc space in vivo, which, in turn, will be determined by other spinal structures (such as ligaments, articular facets, vertebrae, and muscular stabilizers); violation of this mechanical environment could adversely impact LTDR patients, but, frustratingly, such violation also confounds biomechanical and kinematic studies. ${ }^{639}$

Clinical concerns regarding facet arthrosis following LTDR were first published in 2007, when a degradation of index-level facet joints were seen in $36 \%$ and $32 \%$ of patients implanted with SB Charite and ProDisc II LADs, respectively, in a series of 61 patients followed up for a minimum of 3 years. ${ }^{187}$ These results were replicated in a series of 32 patients (41 ProDisc II LADs) with a minimum follow-up of 2 years, in which progression of indexlevel facet degeneration was observed in $29 \%$ of cases, although it was noted that risk of such progression was related to malposition of the prosthesis on the frontal plane and/or to 2-level LTDR. ${ }^{182}$ In a retrospective study of 29 patients requiring revision surgery 16 to 84 months following LTDR using 1 of 3 LADs (SB Charite, $\mathrm{n}=26$; ProDisc II, $\mathrm{n}=2$; Acroflex, $\mathrm{n}=1$ ) because of intractable pain, $5(17 \%)$ had facet fractures on computed tomography scan, $29(100 \%)$ exhibited distraction or compression of the facets, 7 (25\%) had endplate fracture-related subsidence (of less than $4 \mathrm{~mm}$ in 6 of these 7 cases), and $100 \%$ of the 8 patients who underwent pre-revision diagnostic facet injections reported at least partial and temporary relief of persistent leg pain (suggesting that clinically meaningful facet arthrosis was a major contributor to the need for revision). ${ }^{450}$ In a prospective study of 93 patients (108 LADs) implanted with the ProDisc II and with an average follow-up of 53 months and a minimum follow-up 
of 24 months, progression of facet joint degeneration was evident in $20 \%$ of index-level facet joints but was significantly more common following LTDR at the lumbosacral junction than following surgery above this level. ${ }^{446}$ In a prospective study of 116 patients, index-level facet arthrosis appeared or deteriorated in 20 of 59 patients $(34 \%)$ who were randomized to LTDR using the ProDisc II compared with 2 of 57 patients $(4 \%)$ who were randomized to conservative rehabilitative therapy, although the development or progression of facet arthrosis did not relate to clinical outcome in either group (at least by the time of the final [24-month postoperative] follow-up). ${ }^{346}$ Interestingly, no facet changes were evident on independently assessed computed tomographic images secured 3 days postoperatively and again 6 to 24 months postoperatively in a series of 52 patients implanted with the ProDisc II in which the prosthesis was well-centered and where no migration had occurred. ${ }^{184}$

With respect to the ProDisc-L, Shin et al. ${ }^{429}$ reported mean $( \pm \mathrm{SD})$ segmental translation of 0.49 $( \pm 49) \mathrm{mm}$ and of $0.83( \pm 0.78) \mathrm{mm}$ at 1 month and 24 months, respectively, in a series of 35 consecutive patients, but they noted that the observed segmental translation was not associated with progressive facet arthrosis. It should be appreciated, however, that (adjacent) segment translation appears to be worse following lumbar fusion than after LTDR. ${ }^{124,367}$

With respect to clinical data germane to facet arthrosis following LTDR using the ProDisc-L, a retrospective study of 42 patients (51 LADs) followed for at least 3 years classed surgical levels as exhibiting postoperative and radiologically apparent progressive facet arthrosis (PFA; $\mathrm{n}=19$; $37 \%)$ or not exhibiting PFA $(\mathrm{n}=32 ; 63 \%)$, and analysis revealed that preoperative facet tropism (asymmetry in both facet joint angles ${ }^{656}$ ) of greater than $5^{\circ}$ was the only preoperatively identifiable determinant of PFA. ${ }^{337}$ Of note, the clinical implications of PFA following LTDR using the ProDisc-L were not discussed in the aforementioned series, ${ }^{337}$ which remains (to our knowledge) the only publication describing postimplantation facet arthrosis using this LAD, thus emphasizing the need for incidence data in this respect.

In brief, therefore, LDDD is a risk factor for facet arthrosis, ${ }^{655}$ as are each of the surgical procedures aimed at alleviating symptoms attribut- able to this condition, including lumbar interbody fusion, ${ }^{657}$ lumbar discectomy, ${ }^{658,659}$ and LTDR.

Heterotopic Ossification. Heterotopic ossification (HO), which refers to the presence of bone in a soft tissue where bone does not normally exist, has been described following LTDR and is categorized as Class 0 (no HO), Class I (island of bone not within the margins of the disc and not interfering with motion), Class II (bone within the margins of the disc and interfering with ROM), Class III (the range of motion of the vertebral end plates is blocked by the formation of $\mathrm{HO}$ and/or postoperative osteophytes on fexion-extension of lateral bending photographs), or Class IV (bony ankyloses). ${ }^{189}$ In a series of 65 patients (82 LADs) implanted with either the ProDisc (model not specified; $91.5 \%$ ) or SB Charite $(8.5 \%)$, HO was evident in 25 segments $(30.5 \%)$ and was graded as Class I, II, and III in $9.8 \%, 14.6 \%$, and $6.1 \%$ of segments, respectively (there were no cases of Class IV HO). In terms of ROM, visual analog scale (VAS), and Oswestry Disability Index, there was no difference between Class I and II (or, indeed, between patients with these classes of $\mathrm{HO}$ and patients without HO). ${ }^{392}$ Patients with Class III HO were also statistically comparable with those without HO in terms of VAS and Oswestry Disability Index, but the former did exhibit significantly less segmental ROM than the latter. $^{392}$

The observation of HO following LTDR in two singular case reports has prompted some commentators to hypothesize that use of keel-based LADs (such as the ProDisc II and its successor, the ProDisc-L) is more likely to result in this postoperative event. ${ }^{374,399}$ Beyond a reduction in ROM, HO following LTDR can also be associated with radicular pain ${ }^{307}$ and (rarely) with osteolysis (see below). ${ }^{660}$

Osteolysis. Osteolysis (a mode of degradation, which involves the destruction of bone ${ }^{648}$ ) can occur following orthopedic arthroplasty at the interface between bone and implant. ${ }^{661}$ In the case of LTDR, this process is primarily driven by micromotion of the implant and the body's response to wear debris, ${ }^{649}$ because debris particles disrupt bone homeostasis through an inflammatory process and consequential maturation of osteoclasts, thus increasing bone resorption. ${ }^{661}$ Commentators have suggested that the low prevalence of osteolysis 
following LTDR (when compared with, say, total hip replacement) is attributable to the small ROM of LADs. ${ }^{662}$

With respect to the ProDisc-L, a series of 2 patients suffering postimplantation osteolysis has been reported in which retrieved implants and periprosthetic tissue reactions were studied and where osteolytic cysts were evident in adjacent vertebrae. ${ }^{660}$ In the patient who had undergone hybrid LTDR, HO and tissue necrosis due to wearinduced inflammation was observed; in the patient who had undergone nonhybrid LTDR, inflammation was noted in tissue regions with metal and polyethylene wear debris, and the LAD exhibited signs of impingement; these findings suggest that wear debris and inflammation contribute to osteolysis following LTDR, but the authors also noted the rarity of this complication following the procedure. ${ }^{660}$ Furthermore, there is reason to believe that the observed reduction of UHMWPE particle numbers in the case of the contemporary ProDiscL will favorably impact the small risk of postimplantation osteolysis using this LAD. ${ }^{319}$

Vertebral Body-Splitting Fractures. Vertebral bodysplitting fractures are rare following single-level LTDR using the ProDisc-L, the published literature consisting of a series of 2 Asian women (and therefore in which small vertebral bodies may have played a role) in whom no adverse long-term effects were evident as a result of this complication. ${ }^{140}$ However, vertebral body-splitting fractures are more commonly seen following multilevel LTDR using the ProDisc-L and can be associated with sclerotic fracture margins, although the risk of this event can be reduced by modifying the surgical technique. ${ }^{357}$

\section{BENEFITS OF LTDR}

The benefits of LTDR may be classed as those corollary to amelioration of symptomatology and those that are corollary to biomechanical and kinematic considerations.

\section{Benefits Corollary to Amelioration of Symptomatology}

The aforementioned discussion has demonstrated that single-level LTDR is noninferior (or superior) to LIF for the treatment of recalcitrant and symptomatic LDDD presenting with LBP and/or radiculopathy. Given that chronic pain is causal to depression, ${ }^{663}$ social isolation, ${ }^{664}$ and work disability, ${ }^{665}$ and since improved physical capability (in a way that is subjectively appreciated) is reported following implantation of the ProDisc-L, ${ }^{358}$ it is unsurprising that successful LTDR has a profound and positive impact on a patient's quality of life by alleviating these psychosocial consequences of LDDD. Indeed, sex life and sexual function in men and women with symptomatic LDDD has been observed to improve following LTDR in a way that is commensurate with reduction in LBP, but this is not the case for men following LIF. ${ }^{408}$

\section{Benefits Corollary to Biomechanical and Kinematic Considerations}

\section{Background}

A review of in vivo kinematic studies confirms a reduction in overall lumbar ROM (and reports instability at the rostral adjacent level in circa $30 \%$ of patients) following lumbar arthrodesis. ${ }^{532}$ The risk of ASD-indicated surgery following arthrodesis varies from $7 \%$ at two years ${ }^{453}$ to $16.5 \%$ at five years, ${ }^{666}$ and may be as high as $36 \%$ ten years postarthrodesis. ${ }^{666}$

In contrast with arthrodesis, LTDR aims to replicate the complex biomechanical function of the motion segment in a way that improves quality of motion and does not provoke problems in the adjacent segments. ${ }^{633}$ Specifically, LTDR seeks to offer a physiological preservation of motion at the treated motion segment, the putative corollary of which is avoidance of hypermobility and therefore consequential unloading of adjacent segments and, therefore, a reduced risk of ASD. ${ }^{297,298,667-669}$

\section{Design Features of the ProDisc-L (and Its Predecessor, ProDisc II) Germane to Biomechanical and Kinematic Considerations of LTDR}

The SB Charite, which is an unconstrained LAD ${ }^{595}$ that is not keel based, was the most widely implanted device in LTDR surgery until circa 2009. The ProDisc-L LAD (and its predecessor, the ProDisc II) is a semiconstrained device composed of 2 cobalt-chromium-molybdenum endplates covered with a titanium plasma spray coating to promote bony ongrowth into the surface of the implant. The articulating surface is composed of a UHMWPE inlay contacting metal, and a keel at each endplate guides correct intraoperative orienta- 
tion of the LAD and is necessary to primary and long-term fixation. ${ }^{357}$

\section{In Vitro Studies}

In vitro studies investigating adjacent segment biomechanics following LTDR versus arthrodesis are confounded by limitations of current in vitro methodology; for example, testing protocols for flexibility or stiffness under different loading scenarios (eg, pure moment or eccentric load) are premised on erroneous assumptions regarding postoperative motion behavior by the patient. ${ }^{628}$ Notwithstanding and with full appreciation of these limitations, insights have been gained by cadaveric study and warrant mention.

A human cadaveric biomechanical study demonstrated that the degree of implant constraint influences facet/implant surgery and that an unconstrained LAD (with 5 degrees of freedom; SB Charite) at L5-S1 results in increased facet loading that is not seen following implantation of a semiconstrained LAD (with 3 degrees of freedom; ProDisc II) at the same level. ${ }^{253}$ Moreover, when subjected to anterior-posterior shear, the semiconstrained ProDisc-L is more robust to in vitro wear rates than the unconstrained SB Charite. ${ }^{585}$ Further cadaveric study on the impact of the device keel on vertebral compression properties following implantation of the ProDisc-L demonstrated that the keel introduces a reduction in stiffness to the implantendplate interface. ${ }^{638}$ Moreover, another cadaveric biomechanical study has demonstrated that ROM of operated and adjacent motion segments is preserved following implantation of the ProDisc-L at L4-L5, that the kinematics of adjacent segments was unaffected by implantation of this LAD, and that the procedure did not result in significant altered disc pressures in adjacent motion segments. ${ }^{606}$ Finally, a cadaveric study has also compared arthrodesis with LTDR (using the ProDisc-L) in terms of flexion-extension, bilateral lateral bending, and bilateral torsion; the study also compared the results with an intact spine and demonstrated only minimal adjacent-level effects following 1- and 2-level LTDR constructs, whereas 1 - and 2-level fusions resulted in increased adjacentlevel effects in each of the motions tested. ${ }^{298}$

Finite element analyses comparing arthrodesis to LTDR (using the ProDisc II) at the L3-L4 level, using a validated 5-level intact model as a reference, revealed high ROM, annulus stress, and facet pressure at adjacent levels (especially at L2-L3) following arthrodesis, whereas adjacent level instability was not evident following LTDR, indicating that development and progression of ASD is more likely following arthrodesis than following LTDR. $^{623}$

With respect to LTDR versus discectomy (rather than the usual comparator [arthrodesis]), a cadaveric biomechanical study $(\mathrm{n}=7)$ compared L3-L4 facet loading under conditions simulating L4-L5 LTDR, L4-L5 discectomy, and a healthy L4-L5 intervertebral disc and reported significantly greater stress on the L3-L4 facets following L4-L5 discectomy (when compared with normal disc integrity at L4-L5) but no increase in L3-L4 facet loading following L4-L5 LTDR (when compared with normal disc integrity at L4-L5), suggesting that lumbar discectomy may indeed contribute to ASD and that LTDR may confer benefits in this respect over lumbar discectomy. ${ }^{267}$ Indeed, another cadaveric biomechanical study evaluated compressive load in the proximal adjacent segment under various loading scenarios in 3 models (an intact sample, a discectomy sample, and a postimplantation LTDR sample) and reported significantly greater compressive loading in the proximal segment in the discectomy sample when compared with the intact model but no difference between compressive load in the proximal segment in the post-LTDR model versus the intact model, again suggesting that discectomy does indeed represent a greater risk for ASD than LTDR. ${ }^{642}$ The results of these studies are consistent with the those of another cadaveric study $(\mathrm{n}=10)$ that demonstrated that lumbar LTDR at L4-L5 maintained adjacent-level intradiscal and facet force pressures (under variable loading conditions) at values of intact spines, whereas each of these pressures were increased after arthrodesis at L4-L5 (and intradiscal pressures [but not facet force pressures] were also increased following discectomy at L4-L5). ${ }^{587}$

\section{Clinical Studies}

The in vivo postoperative impact on intervertebral mobility of a mobile-core LAD (where the core is free to translate in the transverse plane during flexion-extension and lateral bending, thus allowing a moving axis of rotation and enabling the adjacent vertebrae to rotate without necessary accompanying translation) has been compared with that of a fixedcore design (where motion is allowed by a ball-and- 
socket configuration and where, therefore, the amount of intervertebral translation occurring with rotation is dependent on the radius of the core's curvature; the ProDisc-L), in which it was observed that ROM and motion distribution at implant level were not different between the two LAD designs (ie, a fixed-core design, such as the ProDisc-L, does not sacrifice ROM and yet does not run the risk of possible adverse effects of a mobile-core LAD on facet loading and segmental mobility). ${ }^{383}$

A prospective study of 116 patients who were randomized to LTDR using ProDisc II $(\mathrm{n}=59)$ or conservative rehabilitative therapy $(\mathrm{n}=57)$ and who were followed for a minimum of 2 years afforded a unique opportunity to comment upon ASD as a function of the natural history of LDDD versus ASD following implantation of a LAD, whereupon it was noted that ASD occurred with statistically comparable frequencies in the 2 arms of the study. ${ }^{346}$

Auerbach et al. ${ }^{406}$ analyzed radiographic results 24 months following surgery in a prospective, multicenter RCT comparing single-level LTDR using the ProDisc-L $(\mathrm{n}=155)$ with arthrodesis $(\mathrm{n}=45)$ and reported significant improvement and no change in total lumbar ROM following LTDR at L4-L5 and L5-S1, respectively. Further, LTDR resulted in a significantly greater contribution by the operated level to postoperative total lumbar ROM (L4-L5, -2.5\%; L5-S1, -5.1\%) than did arthrodesis $(-16.8 \%)$. Moreover, the relative contribution by the first cranial adjacent segment to total lumbar ROM increased by $12.1 \%$ following arthrodesis at L5-S1, whereas the respective figure was $-1.2 \%$ following LTDR. Finally, a significantly increased ROM $(6 \%)$ at the first adjacent caudal segment following LTDR was observed, but this was not the case following fusion (3\%). In brief, therefore, LTDR using the ProDisc-L results in slight loss of relative contribution by the operated level to total lumbar ROM, which was compensated (at least after L4-L5 surgery) by the caudal adjacent segment level; in contrast, a far greater loss of contribution to total ROM by the operative level following arthrodesis was demonstrated, and this loss was redistributed among multiple cranial adjacent levels (especially the first cranial adjacent level), indicating that fusion represents greater risk for development and progression of ASD. ${ }^{406}$

In a retrospective review at a single center, further ASD-indicated surgery was required in 20 of 1000
$(2 \%)$ consecutive patients who had undergone LTDR (at a mean postimplantation interval of 28.3 [range 0.5-85] months); of note, some of these patients had been operated within a randomized clinical trial of LTDR versus fusion, affording this surgical center access to 67 arthrodesis procedures for comparison purposes. Of these, 3 (4.5\%) required reoperation to address $\mathrm{ASD}$ (at a mean postimplantation interval of 59.43 [range 40-96] months). ${ }^{355}$ Further, upon review of the pre-LTDR magnetic resonance imaging scans (images were available for 14 of the 20 patients requiring surgery for ASD following LTDR), in no case had ASD progressed following implantation of the LAD. ${ }^{355}$

In 2008, a systematic review reported radiographically evident ASD in 314 of 926 patients (34\%) and 31 of 313 patients $(9 \%)$ following arthrodesis and LTDR, respectively; symptomatic ASD was reported in 173 of 1216 patients $(14 \%)$ and 7 of 595 patients $(1 \%)$ following arthrodesis and LTDR, respectively; these findings prompted a Class C recommendation in favor of LTDR over arthrodesis in an attempt to reduce risk of ASD following surgery for LDDD. ${ }^{251}$

Another systematic review of all cohort studies and randomized, controlled trials germane to ASD following LTDR versus fusion was conducted by Wang et al. ${ }^{504}$ in 2012, in which the overall strength of the evidence for each key question was rated using the Grades of Recommendation Assessment, Development and Evaluation (GRADE). It was reported that (on the basis of moderate evidence) patients who undergo fusion are nearly 6 times more likely to require surgical treatment for ASD (pooled risk from 2 RCTs: 7\%) than patients who undergo LTDR (pooled risk from 2 RCTs: $1.2 \%$ ), but that the limited evidence precluded a definitive statement. $^{504}$

In conclusion, the rationale that LTDR is associated with lower risk of ASD development and progression than arthrodesis is biomechanically and kinematically sound, and it is underpinned and supported by all available in vitro studies. Clinical results also indicate that LTDR is superior to arthrodesis in terms of postoperative ASD development and progression. Although the superiority of LTDR over fusion in terms of ASD risk cannot be said to be definitively proven, patients with symptomatic LDDD considering management options should be informed that the increased risk of ASD development and progression following arthrodesis 
is definitively proven; they should also be informed that development and progression of ASD is also seen following lumbar discectomy and as a consequence of the natural history of LDDD.

\section{CONTRAINDICATIONS AND INDICATIONS FOR LTDR}

\section{Contraindications}

Exclusion criteria for participation in the initial prospective, randomized, multicenter, IDE clinical trial comparing LTDR (using the ProDisc-L) with arthrodesis, published in 2007, were chosen with a view to maximizing comparability of the 2 procedures and minimizing the risk of confounding; they were never intended for adoption as contraindications for the procedure. ${ }^{119}$ Informed by subsequent study and technological developments, and in order to accommodate case-by-case decision making in a real-world setting, the contraindications for LTDR are necessarily less stringent than the exclusion criteria of the initial IDE trial.

For example, LDDD at more than 1 level represented an exclusion criterion for the initial trial, but it has since been shown that 2-level LTDR using the ProDisc-L results in outcomes comparable to those of 1-level LTDR using this LAD. ${ }^{332}$ Also, osteopenia (defined by specific dual energy X-ray absorptiometry bone density measures) was an exclusion criterion in the initial trial, ${ }^{483}$ but subsequent technological advances in vertebral body augmentation now allows greater flexibility in the threshold measures of bone density formerly deemed a contraindication for this procedure. ${ }^{93,600}$

\section{Indications}

In spite of widespread misconceptions, it is important to emphasize that LBP (with or without coexisting radicular pain) attributable to LDDD is not the sole indication for LTDR, and that patients with radicular pain (with or without coexisting LBP) attributable to LDDD should also be considered for this procedure (where symptoms persist beyond a trial of no less than 6 months' conservative treatment). ${ }^{361,483,533}$

Recurrent herniation is not uncommon following primary discectomy for lumbar $\mathrm{DH}^{368}$ and given that prior discectomy compromises the outcome of subsequent arthrodesis ${ }^{416}$ and also subsequent repeat discectomy ${ }^{670}$ but does not compromise the outcome of subsequent LTDR, ${ }^{416}$ the indications for LTDR have been extended to include recurrent DH following primary discectomy. ${ }^{368}$

\section{Financial Implications of LTDR}

Work disability is a major personal, financial, and public health burden, ${ }^{671}$ and annual productivity losses attributable to LBP have been estimated at \$28 billion in the United States alone, ${ }^{672}$ reflecting the observation that LBP affects 600 million people and is the leading cause of disability worldwide. ${ }^{673}$

In the early years of LAD implantation and soon after the first device received FDA approval (October 2004), the Nationwide Inpatient Sample was used to analyze the revision burden following LTDR (11.2\% of 7172) and fusion (5.5\% of 62731$)$ for the years 2005 and 2006. The analysis found that the revision burden for LTDR fell well within the revision burden range for hip and knee replacement surgeries and noted that these latter procedures are generally considered cost effective. ${ }^{398}$ In 2007, a cost-minimization model was employed to assess the financial implications of LTDR (using the SB Charite) versus 3 different techniques of lumbar fusion; the conclusion was that LTDR is likely to be more cost effective than arthrodesis (or, at worst, equivalent to arthrodesis). ${ }^{252}$

An in-depth financial analysis of 10 randomly selected patients from each arm of the ProDisc-L IDE RCT concluded that the hospital costs associated with LTDR are similar to transforaminal interbody fusion and to anterior spinal fusion (after excluding costs associated with recombinant human bone morphogenetic protein-2) but are significantly less than posterior spinal fusion. ${ }^{199}$

In a cohort of 53 prospectively studied patients undergoing 1- or 2-level LTDR using the ProDisc-L and 17 patients undergoing circumferential fusion for 1- or 2-level LDDD, in-depth analysis encompassing a wide range of financial parameters (eg, operating time, cost of implants, surgical and anaesthetic fees, hospital charges, length of stay, etc) revealed that patients undergoing 1-level ProDisc-L LTDR represented a significantly smaller financial burden than those undergoing 1-level arthrodesis (while charges were comparable for the 2 procedures for patients undergoing 2-level surgery). ${ }^{104}$

A cost comparison of patients undergoing 3-level LTDR (using the ProDisc-L; $\mathrm{n}=21$ ) versus 3-level arthrodesis $(\mathrm{n}=22)$ revealed significantly lower costs in association with LTDR, and this was 
attributable to a mean of 3 fewer hospital days for patients implanted with an LAD. 449

A randomized, controlled health economic study with 2 years' follow-up, using a design that factors in the cost to the individual and to society (eg, return to work, number of sick days, gain in qualityadjusted life years, etc), compared patients undergoing single-level LTDR $(\mathrm{n}=80)$ using a variety of LADs (ProDisc-L, $\mathrm{n}=28$; SB Charite, $\mathrm{n}=26$; Maverick, $\mathrm{n}=26)$ versus lumbar fusion $(\mathrm{n}=72)$; the study concluded that LTDR is the more cost effective of the 2 surgical approaches. ${ }^{445}$

Another study compared 50562 lumbar fusion procedures with 2415 LTDR procedures in terms of the need for reoperation and reported that LTDR was associated with significantly less risk of subsequent lumbar surgery in the first postoperative year $(2.94 \%$ versus $4.01 \%)$, although no significant differences were observed between the 2 surgical approaches at 3-year and 5-year follow-up. ${ }^{304}$

Finally, analysis of Medicare Benefits Schedule claims data in Australia was used to compare the cost effectiveness of LTDR versus lumbar fusion and concluded that, overall, LTDR represented a cost-saving procedure when arthrodesis is the comparator. ${ }^{500}$

In summary, therefore, it appears that LTDR is more cost effective than its typical comparator (arthrodesis) from the perspective of patients, of society, and of health care providers.

\section{UPTAKE BY SPINAL SURGEONS}

An offer of LTDR to patients with LDDD has become more likely in recent years, ${ }^{445}$ but the anticipated rapid and widespread adoption of this procedure by spinal surgeons did not follow its FDA approval in 2004. ${ }^{556}$

For example, a retrospective analysis of the Nationwide Inpatient Sample between 2000 and 2009 revealed that surgical treatment for LDDD had increased 2.4-fold in the United States during this period, and this was reflected in an increase in all fusion procedures but not in LTDR. ${ }^{488}$ Indeed, 911 LTDR procedures were performed in the United States in 2005 (a period commencing 3 months after FDA approval), and this had declined to 653 LTDR procedures by $2008 .^{510}$ At that time, these observations seemed to reflect the views of United States-based spinal surgeons; for example, of 133 surveyed spinal surgeons, 64\% said they were less likely to perform LTDR than they would have been 1 year previously (although $42 \%$ of them had performed LTDR in the past), whereas $81 \%$ were more likely to perform cervical total disc replacement than they had been 1 year previously (although only $30 \%$ of them had ever performed this latter procedure) ${ }^{527}$ However, the initial poor uptake of LTDR by spinal surgeons should be interpreted with full appreciation that less than $1 \%$ of those surveyed at the 2009 Annual Meeting of the American Orthopaedic Association said that they would opt for (any) surgical treatment if they personally and hypothetically suffered from chronic LBP attributable to LDDD, and, at that time, $77 \%$ of respondents persisted in the (now untenable ${ }^{9}$ ) view that the intervertebral disc is not the major cause of low back pain. ${ }^{521}$ Moreover, in 2011, one retrospective study misleadingly reported that only $14.9 \%$ of patients with LDDD requiring surgery would be eligible for LTDR if all the exclusion criteria for the IDE trial (including diabetes mellitus and history of chronic disease) were to be (inappropriately) deemed contraindications for the procedure, but that this figure rose to $25.8 \%$ when only absolute contraindications were applied (the study still controversially deemed, for example, LDDD affecting more than 1 level as a contraindication). ${ }^{551}$

However, dampening enthusiasm for LTDR plateaued in or around 2009, and we are now in a period of slow but steady growth of the procedure, reflected in the publication of 178 surgical series since that time. In brief, LTDR has survived a difficult introduction to the spinal surgical community, is not being discarded by that community, and is now gaining acceptance by that community.

Notwithstanding the observations that LTDR is proven to be noninferior (or superior) to lumbar fusion, that the risk of postsurgical ASD development and/or progression appears to be less following LTDR when compared with arthrodesis, and that LTDR is more cost effective than lumbar fusion, the slow growth of LTDR is unsurprising because of the challenges inherent in the safe introduction of this procedure to a health care facility. These challenges can be classed as financial, logistical, and regulatory, and they are inextricably interdependent.

The logistical challenges in any attempt to safely introduce LTDR to a facility include, but are not restricted to, the following: flexibility in relation to access to intensive care facilities; the perceived need by some spinal surgical centers for a vascular 
surgeon to perform some of the surgery, or at least to be on standby ${ }^{445}$; the need for at least 2 spinal surgeons trained in LTDR to be available for crosscover and to work together in a noncompetitive environment of collegiality; training of theater and ward staff; and development of a streamlined process in terms of preoperative and postoperative care. Of course, each of these logistical challenges has financial implications for the proposed surgeons and the proposed health care facility (see below) and are not unrelated to regulatory issues (see below).

Any endeavor to safely introduce LTDR to a facility has financial implications, and these can be classed as those relating to the patient, those relating to the facility, and those relating to surgical and medical staff. Clearly, where an insurance-dominated health care system does not provide financial cover for the subscriber's preferred treatment option of a proven noninferior procedure, demand for the procedure will be low (and this, in turn, will have implications for surgical volume and corollary adverse implications for retention of appropriate spinal surgical skills ${ }^{674}$ ). And if the eligibility criteria for supporting the procedure are too restrictive and fail to reflect advances since the initial trials that have confirmed noninferiority of LTDR when compared with fusion, patient demand and surgical skills are adversely affected. ${ }^{510}$ In this scenario, surgeons may find themselves in the unenviable position of doing the bidding of the insurance companies (ie, acting as a rationing device). The financial implications for the surgeon also need to be addressed, as remuneration of a surgeon's time represents the basis of any relationship between a health insurance company and a service provider; again, nonremuneration of the surgeon in respect of LTDR may compel the surgeon to discontinue the LTDR service, again with adverse implications for patients and skills. Finally, a health care facility has running costs and also needs to be appropriately remunerated for LTDR, a procedure which has been shown to be noninferior and more cost effective than spinal fusion. Financial uncertainties surrounding any attempt to safely introduce LTDR will inevitably prevent the health care facility from committing resources to the proposed new service. Further, these financial uncertainties are, at least in part, related to regulatory issues.

The regulatory issues surrounding the safe introduction of LTDR can be classed as those relating to FDA (or equivalent) approval, those relating to eligibility criteria for financial support laid down by the health insurance companies, and those relating to professional standards of medical, paramedical, and nursing staff. FDA approval for LTDR is for single-level surgery only, because the IDE trial was designed and powered to test whether single-level LTDR was noninferior to spinal fu$\operatorname{sion}^{510}$ (notwithstanding the observation that 2-level and 1-level LTDR are equivalent [in the same IDE trial] in terms of clinical outcomes ${ }^{332}$ ). In spite of a growing body of subsequent studies that indicate that several of the exclusion criteria of the original IDE trial should not be deemed contraindications to LTDR, many health insurance companies nevertheless inappropriately adopted these trial-specific exclusion criteria as eligibility criteria for financial support for LTDR, and they continue to do so (again, with adverse consequences for demand by patients for the procedure and its uptake by surgeons). ${ }^{510}$ Finally, the regulatory demands on surgeons and paramedical and nursing staff are exacting, and, in a litigious environment, medicolegal considerations discourage personnel from conducting a procedure that might not fulfill all eligibility criteria (even nonclinical criteria and irrespective of the perceived [in]appropriateness of such criteria $\left.{ }^{675}\right){ }^{676}$

The problems are best exemplified by the hypothetical surgeon who wants to introduce this noninferior and cost-effective procedure to his/her practice. First, the surgeon trains (or retrains) in a center of excellence for LTDR because of the unfamiliar nature of the procedure, and he or she ensures that a committed and competent colleague does likewise (and that someone looks after their practices in the interim, and that their mortgages are also paid). Of course, before committing to this sabbatical period of training, the spinal surgeon has secured (in writing) a commitment from the local health insurance companies to support LTDR in a nonrestrictive fashion (so that demand will ensure sufficient volume to maintain surgical proficiency and also so that the health care facility will be in a position to commit to this expansion of services) in a way that is not contingent upon the FDA altering the nature of its approval for single-level LTDR only (alternatively, or in addition, the surgeon has persuaded the FDA to alter the nature of its approval for LADs).

Clearly, this is breathtakingly difficult. 
The delivery of health care in much of the English-speaking world is insurance based, and therefore, in essence, neoconservative in outlook (ie, "Faster, better, cheaper"). This system of health care provision does not lend itself to the introduction of innovative surgical procedures; accordingly, many patients from English-speaking countries find themselves compelled to travel to other jurisdictions if they want to avail of LTDR and other technologies. ${ }^{677}$

\section{FUTURE PERSPECTIVES AND CHALLENGES}

Notwithstanding the fact that one can now make an evidence-based assertion that LTDR is (at least) noninferior to lumbar fusion for many patients with LDDD, there remains a need to study and publish the long-term sequelae of this procedure. For example, what are the cumulative risks of devicerelated complications such as migration, subsidence, and biological reactions to UHMWPE particles after, say, 10 or 15 years? Equally, what is the risk of ASD 10 or 15 years after the procedure, and how does this risk compare with lumbar discectomy (LD), lumbar fusion, and the natural history of LDDD? Does LTDR mitigate against nonspinal sequelae of LDDD (such as osteoarthritis of the knee $\left.^{678}\right)$ ?

The longest follow-up of LTDR was published in 2006 , in a series of 53 patients with an average follow-up of 17 years and where first-generation LADs (now discontinued) were implemented, and where spontaneous ankylosis was seen in association with 32 of 63 LTDRs $(60 \%)$, necessitating a secondary surgical procedure in 5 patients $(9 \%){ }^{138}$ Data germane to the ProDisc-L in terms of these observations and other outcomes and in the context of comparable periods of follow-up should be available, and these should be published.

With respect to future study, expansion of indications for LTDR need to be investigated. Specifically, an RCT of LTDR versus repeat lumbar discectomy in cases of recurrent disc herniation following primary LD is warranted (because primary $L D$ adversely impacts outcomes of repeat $\operatorname{LD}^{670}$ but does not adversely impact outcomes of $\mathrm{LTDR}^{416}$ ). Furthermore, future studies should attempt to identify preoperative prognostic indicators for LTDR versus its comparator and should factor in familiarity of the operating surgeons with each procedure into analyses.
It is widely acknowledged that the spinal surgical community is poorly served by the literature in respect of the management of low back pain. ${ }^{679}$ Nevertheless, there is ample evidence to assert that LTDR is noninferior (and possibly superior) to lumbar fusion in patients with recalcitrant symptoms of back and/or radicular pain attributable to LDDD. The challenge rests on making this procedure more accessible to patients, to surgeons, and to health care facilities, and therefore addressing the logistic, financial, and regulatory issues that hamper the safe introduction of LTDR to a facility. It is incumbent upon spinal surgeons to work, together, to this end.

Rational debate surrounding LTDR is as legitimate as it is healthy. Advocates for the procedure point out that it is (at least) noninferior to spinal fusion for appropriately selected patients, that motion is not sacrificed, and that it may confer protections against subsequent development or progression of ASD, and they point to the published literature in support of this position. ${ }^{483}$ Hesitation in introducing LTDR to a health care facility is, however, equally justified, given the aforementioned difficulties in doing so safely.

Spurious arguments against LTDR have, however, occasionally been articulated and are seen by some as a contrivance to disparage a procedure that has been tried, tested, and shown to be an evidencebased, motion-preserving, and noninferior alternative to spinal fusion for many patients with LDDD. $^{483}$

Examples of specious arguments (and their respective rebuttals, in parenthesis and italics) include the following:

- "LTDR is a novel or experimental procedure." (LTDR has been performed since the late 1980s and has been FDA approved since 2004.)

- "LDDD is a benign disease and doesn't warrant the risks of LTDR." (Any condition causing pain, depression, and social isolation cannot be labeled "benign"; in any case, only a patient can subjectively grade severity of disease and how it impacts his/her quality of life.)

- "Longer-term data are needed." (Longer-term data on LTDR are indeed required, and such data continue to emerge; however, the current lack of such data should not preclude disclosure of the existence and proven benefits of a noninferior procedure, just as lack of long-term data did not preclude patients from having access 
to total hip and knee replacements in the 1990s. Finally, the longer-term data we have on spinal fusion, in terms of ASD and in terms of reoperation, hardly represent a defense of spinal fusion.)

- "LTDR is only indicated in cases of discogenic back pain." (This is not true; LTDR is indicated in cases of $L B P$ and/or radicular pain attributable to $L D D D$.)

- "Well, personally, I don't believe in the procedure." (No doctor should feel under pressure to advocate a procedure he/she doesn't believe in; however, the failure to disclose and discuss the existence of a noninferior procedure could be ethically and legally problematic.)

- "It's simply too risky." (The risks inherent in $L T D R$ and spinal fusion need to be thoroughly explained, and patients should also understand that the natural course of LDDD is not necessarily benign and that adverse sequelae related to persistent and chronified pain [depression, social isolation, sexual dysfunction, etc] and to disease progression [ASD, scoliosis, osteoarthritis of the knee, etc] can occur; in the absence of full disclosure, ethical and legal issues may arise.)

In brief, it rests on the patient (and not the doctor) to make an informed and personalized decision regarding the risks and benefits of LTDR in his/her case, and the patient's ability to do so depends on a patient-centered disclosure by the doctor.

\section{ETHICAL AND MEDICO-LEGAL IMPLICATIONS OF LTDR FOR THE SPINAL SURGEON}

The ethical and legal requirements for informed consent prior to a proposed procedure derives from the concept of personal (patient) autonomy. ${ }^{680}$ The competent patient can only make a voluntary, uncoerced, and informed decision to proceed following disclosure (by the treatment provider) and understanding (by the patient) of the risks and benefits of the proposed surgery and of alternative approaches. In other words, patient-centered medicine $^{681}$ cannot be practiced in the absence of shared decision making and patient-centered disclosure. ${ }^{682}$ This is particularly true for spinal surgery, ${ }^{683}$ especially given the concern expressed regarding the Internet as a source of information germane to
LTDR. ${ }^{526}$ Accordingly, a spinal surgeon who proposes lumbar fusion to a patient with LDDD but who fails to disclose and discuss an existing alternative and noninferior procedure (such as LTDR) is not fulfilling his/her duty of care to that patient and, as a result, is exposed professionally and legally. It is important also that there is documentary evidence of the spinal surgeon's full disclosure, given that weaknesses in the consenting procedure are major contributors to successful claims against doctors ${ }^{684}$ and given that most postoperative patients don't recall any preoperative discussion regarding alternative treatment options. ${ }^{685}$

Examples of grievances that a dissatisfied postfusion patient might allege in the absence of full and documented preoperative disclosure regarding LTDR include the uninformed nature of the consent procedure and a consequential lack of awareness of an alternative operation that is proven to be noninferior and motion preserving and that may prevent progression of ASD. Clearly, and in the event of an arthrodesis-specific complication, the patient can allege that this adverse event would not have occurred if he/she had been allowed to opt for LTDR.

Grievances may not be restricted to dissatisfied postfusion patients and may be voiced by patients with LDDD who declined an offer of spinal fusion but who were never informed of LTDR. In this scenario, allegations could include that the decision to decline surgery was uninformed and made on the basis of a lack of awareness of a motion-preserving and noninferior alternative to arthrodesis. Further, the concept of pain chronification ${ }^{686}$ and the progressive nature of LDDD should be explained to the patient in a timely manner, as undue delay could compromise the clinical outcome of LTDR ${ }^{417}$ and because a patient may wish to minimize his/her risk of ASD development or progression on the basis of LTDR's putative protective effect in this regard.

Finally, and given the confrontational nature of litigation, a litigant could contend (by innuendo or otherwise) that the failure of the spinal surgeon to disclose the noninferior alternative was financially motivated.

Ultimately, the right to control one's own life and decide what happens to one's own body are wellestablished legal and ethical principles. Choosing to undergo or forego medical or surgical treatment 
requires the patient (not the doctor) to balance the potential risks and benefits of different approaches so the patient (not the doctor) can make an informed choice about what happens to his or her body.

After all, some of us are doctors, but we are all patients.

\section{CONCLUSION}

LTDR is a noninferior alternative to lumbar fusion for many patients with LBP and/or radicular pain attributable to LDDD. Irrespective of whether spinal surgeons are advocates of LTDR, if they are to advocate for their patients, they must disclose the existence and discuss the concept of this procedure to patients who might benefit from it.

\section{REFERENCES}

1. Fardon DF, Williams AL, Dohring EJ, Murtagh FR, Gabriel Rothman SL, Sze GK. Lumbar disc nomenclature: version 2.0: recommendations of the combined task forces of the North American Spine Society, the American Society of Spine Radiology, and the American Society of Neuroradiology. Spine (Phila Pa 1976). 2014;39(24):E1448-E1465.

2. Modic MT, Masaryk TJ, Ross JS, Carter JR. Imaging of degenerative disk disease. Radiology. 1988;168(1):177-186.

3. Modic MT, Herfkens RJ. Intervertebral disk: normal age-related changes in MR signal intensity. Radiology. 1990;177(2):332-333; discussion 333-334.

4. Marinelli NL, Haughton VM, Anderson PA. T2 relaxation times correlated with stage of lumbar intervertebral disk degeneration and patient age. AJNR Am J Neuroradiol. 2010;31(7);1278-1282.

5. Yasuma T, Koh S, Okamura T, Yamauchi Y. Histological changes in aging lumbar intervertebral discs. Their role in protrusions and prolapses. J Bone Joint Surg Am. 1990;72(2):220-229.

6. Fardon DF, Williams AL, Dohring EJ, Murtagh FR, Gabriel Rothman SL, Sze GK. Lumbar disc nomenclature: version 2.0: recommendations of the combined task forces of the North American Spine Society, the American Society of Spine Radiology and the American Society of Neuroradiology. Spine. 2014;14(11):2525-2545.

7. Kim SJ, Lee TH, Lim SM. Prevalence of disc degeneration in asymptomatic Korean subjects. Part 1 : lumbar spine. J Korean Neurosurg Soc. 2013;53(1):31-38.

8. Maus TP, Aprill CN. Lumbar diskogenic pain, provocation diskography, and imaging correlates. Radiol Clin North Am. 2012;50(4):681-704.

9. Bogduk N, Aprill C, Derby R. Lumbar discogenic pain: state-of-the-art review. Pain Med. 2013;14(6);813-836.

10. McNally DS, Shackleford IM, Goodship AE, Mulholland RC. In vivo stress measurement can predict pain on discography. Spine (Phila Pa 1976). 1996;21(22):2580-2587.

11. Moneta GB, Videman T, Kaivanto K, et al. Reported pain during lumbar discography as a function of anular ruptures and disc degeneration. A re-analysis of 833 discograms. Spine (Phila Pa 1976). 1994;19(17):1968-1974.

12. Hadjipavlou AG, Tzermiadianos MN, Bogduk N, Zindrick MR. The pathophysiology of disc degeneration: a critical review. J Bone Joint Sur Br. 2008;90(10):1261-1270.

13. Frymoyer JW. Back pain and sciatica. $N$ Engl J Med. 1988;318(5):291-300.

14. Porchet F, Wietlisbach V, Burnand B, Daeppen K, Villemure JG, Vader JP. Relationship between severity of lumbar disc disease and disability scores in sciatica patients. Neurosurgery. 2002;50(6):1253-1259; discussion 1259-1260.

15. Ergun T, Lakadamyali H. CT and MRI in the evaluation of extraspinal sciatica. $B r \quad J$ Radiol. 2010;83(993):791-803.

16. Ropper AH, Zafonte RD. Sciatica. $N$ Engl J Med. 2015;372(13):1240-1248.

17. Lindblom K, Rexed B. Spinal nerve injury in dorsolateral protrusions of lumbar disks. J Neurosurg. 1948;5(5):413432.

18. Gardner A, Gardner E, Morley T. Cauda equina syndrome: a review of the current clinical and medico-legal position. Eur Spine J. 2011;20(5):690-697.

19. Lee Y, Lee $\mathrm{CH}, \mathrm{Oh} \mathrm{U}$. Painful channels in sensory neurons. Mol Cells. 2005;20(3):315-324.

20. van der Windt DA, Simons E, Riphagen II, et al. Physical examination for lumbar radiculopathy due to disc herniation in patients with low-back pain. Cochrane Database Syst Rev. 2010;(2):CD007431.

21. Vroomen PC, de Krom MC, Knottnerus JA. Predicting the outcome of sciatica at short-term follow-up. Br J Gen Pract. 2002;52(475):119-123.

22. Luijsterburg PA, Verhagen AP, Ostelo RW, van Os TA, Peul WC, Koes BW. Effectiveness of conservative treatments for the lumbosacral radicular syndrome: a systematic review. Eur Spine J. 2007;16(7):881-899.

23. Valat JP, Genevay S, Marty M, Rozenberg S, Koes B. Sciatica. Best Pract Res Clin Rheumatol. 2010;24(2):241-252.

24. Carette S, Leclaire R, Marcoux S, et al. Epidural corticosteroid injections for sciatica due to herniated nucleus pulposus. N Engl J Med. 1997;336(23):1634-1640.

25. Ashworth J, Konstantinou K, Dunn KM. Prognostic factors in non-surgically treated sciatica: a systematic review. BMC Musculokelet Disord. 2011;12;208.

26. Kreiner DS, Hwang SW, Easa JE, et al. An evidencebased clinical guideline for the diagnosis and treatment of lumbar disc herniation with radiculopathy. Spine $J$. 2014;14(1);180-191.

27. Lewis R, Williams N, Matar HE, et al. The clinical effectiveness and cost-effectiveness of management strategies for sciatica: systematic review and economic model. Health Technol Assess. 2011;15(39):1-578.

28. Lewis RA, Williams NH, Sutton AJ, et al. Comparative clinical effectiveness of management strategies for sciatica: systematic review and network meta-analyses. Spine $J$. 2015;15(6):1461-1477.

29. Machado GC, Witzleb AJ, Fritsch C, Maher CG, Ferreira PH, Ferreira ML. Patients with sciatica still experience pain and disability 5 years after surgery: A systematic review with meta-analysis of cohort studies. Eur $J$ Pain. 2016;20(10):1700-1709.

30. Matsumoto M, Okada E, Toyama Y, Fujiwara H, 
Momoshima S, Takahata T. Tandem age-related lumbar and cervical intervertebral disc changes in asymptomatic subjects. Eur Spine J. 2013;22(4):708-713.

31. Chan WC, Sze KL, Samartzis D, Leung VY, Chan D. Structure and biology of the intervertebral disk in health and disease. Orthop Clin North Am. 2011;42(4):447-464, vii.

32. Roh JS, Teng AL, Yoo JU, Davis J, Furey C, Bohlman $\mathrm{HH}$. Degenerative disorders of the lumbar and cervical spine. Orthop Clin North Am. 2005;36(3):255-262.

33. Kao PY, Chan D, Samartzis D, Sham PC, Song YQ. Genetics of lumbar disk degeneration: technology, study designs, and risk factors. Orthop Clin North Am. 2011;42(4):479-486, vii.

34. Janeczko L, Janeczko M, Chrzanowski R, Zielinski G. The role of polymorphisms of genes encoding collagen IX and XI in lumbar disc disease. Neurol Neurochir Pol. 2014;48(1):6062.

35. Rajasekaran S, Kanna RM, Senthil N, et al. Genetic susceptibility of lumbar degenerative disc disease in young Indian adults. Eur Spine J. 2015;24(9):1969-1975.

36. O'Connell GD, Vresilovic EJ, Elliott DM. Human intervertebral disc internal strain in compression: the effect of disc region, loading position, and degeneration. J Orthop Res. 2011;29(4):547-555.

37. Tsantrizos A, Ito K, Aebi M, Steffen T. Internal strains in healthy and degenerated lumbar intervertebral discs. Spine (Phila Pa 1976). 2005;30(19):2129-2137.

38. Boxberger JI, Sen S, Yerramalli CS, Elliott DM. Nucleus pulposus glycosaminoglycan content is correlated with axial mechanics in rat lumbar motion segments. $J$ Orthop Res. 2006;24(9):1906-1915.

39. Natarajan RN, Andersson GB. Lumbar disc degeneration is an equally important risk factor as lumbar fusion for causing adjacent segment disc disease. J Orthop Res. 2016;35(1):123-130.

40. Boos N, Weissbach S, Rohrbach H, Weiler C, Spratt KF, Nerlich AG. Classification of age-related changes in lumbar intervertebral discs: 2002 Volvo Award in basic science. Spine (Phila Pa 1976). 2002;27(23):2631-2644.

41. Antoniou J, Steffen T, Nelson F, et al. The human lumbar intervertebral disc: evidence for changes in the biosynthesis and denaturation of the extracellular matrix with growth, maturation, ageing, and degeneration. $J$ Clin Invest. 1996;98(4):996-1003.

42. Urban JP, Winlove CP. Pathophysiology of the intervertebral disc and the challenges for MRI. Journal of magnetic resonance imaging. J Magn Reson Imaging. 2007;25(2):419-432.

43. Eyre DR, Muir H. Quantitative analysis of types I and II collagens in human intervertebral discs at various ages. Biochim Biophys Acta. 1977;492(1):29-42.

44. Moore RJ, Vernon-Roberts B, Fraser RD, Osti OL, Schembri M. The origin and fate of herniated lumbar intervertebral disc tissue. Spine (Phila Pa 1976). 1996;21(18):2149-2155.

45. Murphy DR, Hurwitz EL, McGovern EE. A nonsurgical approach to the management of patients with lumbar radiculopathy secondary to herniated disk: a prospective observational cohort study with follow-up. $J$ Manipulative Physiol Ther. 2009;32(9):723-733.

46. Shin JS, Lee J, Lee YJ, et al. Long-term course of alternative and integrative therapy for lumbar disc herniation and risk factors for surgery: a prospective observational 5-year follow-up study. Spine (Phila Pa 1976). 2016;41(16):E955E963.

47. Yu PF, Jiang FD, Liu JT, Jiang H. Outcomes of conservative treatment for ruptured lumbar disc herniation. Acta Orthop Belg. 2013;79(6):726-730.

48. Chiu CC, Chuang TY, Chang KH, Wu CH, Lin PW, Hsu WY. The probability of spontaneous regression of lumbar herniated disc: a systematic review. Clin Rehabil. 2015;29(2):184-195.

49. Simpson EK, Parkinson IH, Manthey B, Fazzalari NL. Intervertebral disc disorganization is related to trabecular bone architecture in the lumbar spine. $J$ Bone Miner Res. 2001;16(4):681-687.

50. Boden SD, Riew KD, Yamaguchi K, Branch TP, Schellinger D, Wiesel SW. Orientation of the lumbar facet joints: association with degenerative disc disease. $J$ Bone Joint Surg Am. 1996;78(3):403-411.

51. Van Goethem JW, Van de Kelft E, Biltjes IG, et al. MRI after successful lumbar discectomy. Neuroradiology. 1996;38(Suppl 1):S90-S96.

52. Ross JS, Delamarter R, Hueftle MG, et al. Gadolinium-DTPA-enhanced MR imaging of the postoperative lumbar spine: time course and mechanism of enhancement. AJR Am J Roentgenol. 1989;152(4):825-834.

53. Itoh R, Murata K, Kamata M, Mukubou N, Morita R. Lumbosacral nerve root enhancement with disk herniation on contrast-enhanced MR. AJNR Am J Neuroradiol. 1996;17(9):1619-1625.

54. Jinkins JR. MR of enhancing nerve roots in the unoperated lumbosacral spine. AJNR Am J Neuroradiol. 1993;14(1):193-202.

55. Crisi G, Carpeggiani P, Trevisan C. Gadoliniumenhanced nerve roots in lumbar disk herniation. AJNR Am J Neuroradiol. 1993;14(6):1379-1392.

56. Lane JI, Koeller KK, Atkinson JL. Enhanced lumbar nerve roots in the spine without prior surgery: radiculitis or radicular veins? AJNR Am J Neuroradiol. 1994;15(7):13171325.

57. Lee JC, Kim MS, Shin BJ. An analysis of the prognostic factors affecting the clinical outcomes of conventional lumbar open discectomy: clinical and radiological prognostic factors. Asian Spine J. 2010;4(1):23-31.

58. Wilson CA, Roffey DM, Chow D, Alkherayf F, Wai EK. A systematic review of preoperative predictors for postoperative clinical outcomes following lumbar discectomy. Spine J. 2016;16(11):1413-1422.

59. Jacobs WC, van Tulder M, Arts M, et al. Surgery versus conservative management of sciatica due to a lumbar herniated disc: a systematic review. Eur Spine J. 2011;20(4):513522 .

60. Dohrmann GJ, Mansour N. Long-term results of various operations for lumbar disc herniation: analysis of over 39,000 patients. Med Princ Pract. 2015;24(3):285-290.

61. Peul WC, van Houwelingen HC, van den Hout WB, et al. Surgery versus prolonged conservative treatment for sciatica. $N$ Engl J Med. 2007;356(22):2245-2256.

62. Weinstein JN, Tosteson TD, Lurie JD, et al. Surgical vs nonoperative treatment for lumbar disk herniation: the Spine 
Patient Outcomes Research Trial (SPORT): a randomized trial. JAMA. 2006;296(20):2441-2450.

63. Lurie JD, Tosteson TD, Tosteson AN, et al. Surgical versus nonoperative treatment for lumbar disc herniation: eight-year results for the spine patient outcomes research trial. Spine (Phila Pa 1976). 2014;39(1):3-16.

64. Gibson JN, Waddell G. Surgical interventions for lumbar disc prolapse: updated Cochrane Review. Spine (Phila Pa 1976). 2007;32(16):1735-1747.

65. Erbayraktar S, Acar F, Tekinsoy B, Acar U, Guner EM. Outcome analysis of reoperations after lumbar discectomies: a report of 22 patients. Kobe J Med Sci. 2002;48(1-2), 3341.

66. Lee YC, Zotti MG, Osti OL. Operative management of lumbar degenerative disc disease. Asian Spine $J$. 2016;10(4):801-819.

67. Bydon M, De la Garza-Ramos R, Macki M, Baker A, Gokaslan AK, Bydon A. Lumbar fusion versus nonoperative management for treatment of discogenic low back pain: a systematic review and meta-analysis of randomized controlled trials. J Spinal Discord Tech. 2014;27(5):297-304.

68. Phillips FM, Slosar PJ, Youssef JA, Andersson G, Papatheofanis F. Lumbar spine fusion for chronic low back pain due to degenerative disc disease: a systematic review. Spine (Phila Pa 1976). 2013;38(7):E409-E422.

69. Wang JC, Dailey AT, Mummaneni PV, et al. Guideline update for the performance of fusion procedures for degenerative disease of the lumbar spine. Part 8: lumbar fusion for disc herniation and radiculopathy. $J$ Neurosurg Spine. 2014;21(1):48-53.

70. Lee JC, Choi SW. Adjacent segment pathology after lumbar spinal fusion. Asian Spine J. 2015;9(5):807-817.

71. Park CK. Total disc replacement in lumbar degenerative disc diseases. $J$ Korean Neurosurg. 2015;58(5):401-411.

72. Fernstrom U. Arthroplasty with intercorporal endoprothesis in herniated disc and in painful disc. Acta Chir Scand Suppl. 1966;357:154-159.

73. Buttner-Janz K, Schellnack K, Zippel H. [An alternative treatment strategy in lumbar intervertebral disk damage using an SB Charite modular type intervertebral disk endoprosthesis]. Z Orthop Ihre Grenzgeb. 1987;125(1):1-6.

74. Buttner-Janz K, Schellnack K. [Principle and initial results with the Charite Modular type SB cartilage disk endoprosthesis]. Magy Traumatol Orthop Helyreallito Seb. 1988;31(2):136-140.

75. Vital JM, Boissiere L. Total disc replacement. Orthop Traumatol Surg Res. 2014;100(1 Suppl):S1-S14.

76. Buttner-Janz K, Schellnack K. [Intervertebral disk endoprosthesis-development and current status]. Beitr Orthop Traumatil. 1990;37(3):137-147.

77. Zippel H, Schellnack K, Buttner K. [Exchanging intervertebral disks. The concept and clinical experience using a cement-free intervertebral disk endoprosthesis of the "Charite Modular SB" type]. Chir Narzadow Ruchu Orthop Pol. 1986;51(4):245-248.

78. Delamarter RB, Bae HW, Pradhan BB. Clinical results of ProDisc-II lumbar total disc replacement: report from the United States clinical trial. Orthop Clin North Am. 2005;36(3):301-313.

79. Lemaire JP, Skalli W, Lavaste F, et al. Intervertebral disc prosthesis. Results and prospects for the year 2000. Clin Orthop Relat Res. 1997;(337):64-76.

80. Griffith SL, Shelokov AP, Buttner-Janz K, LeMaire JP, Zeegers WS. A multicenter retrospective study of the clinical results of the LINK SB Charite intervertebral prosthesis. The initial European experience. Spine (Phila Pa 1976). 1994;19(16):1842-1849.

81. David T. Lumbar disc prosthesis. Surgical technique, indications and clinical results in 22 patients with a minimum of 12 months follow-up. Eur Spine J. 1993;1(4):254-259.

82. Cinotti G, David T, Postacchini F. Results of disc prosthesis after a minimum follow-up period of 2 years. Spine (Phila Pa 1976). 1996;21(8):995-1000.

83. Ross ER, Tandon V. A pilot study of intervertebral disc replacement. J Back Musculoskelet Rehabil. 1997;9(1):69.

84. Tropiano P, Huang RC, Girardi FP, Cammisa FP Jr, Marnay T. Lumbar total disc replacement. Seven to eleven-year follow-up. J Bone Joint Surg Am. 2005;87(3):490-496.

85. Enker P, Steffee A, McMillin C, Keppler L, Biscup R, Miller S. Artificial disc replacement. Preliminary report with a 3-year minimum follow-up. Spine (Phila Pa 1976). 1993;18(8):1061-1070.

86. Buttner-Janz K, Schellnack K, Zippel H. Biomechanics of the SB Charite lumbar intervertebral disc endoprosthesis. Int Orthop. 1989;13(3):173-176.

87. Aharinejad S, Bertagnoli R, Wicke K, Firbas W, Schneider B. Morphometric analysis of vertebrae and intervertebral discs as a basis of disc replacement. Am J Anat. 1990;189(1):69-76.

88. Kostuik JP. Intervertebral disc replacement. Experimental study. Clin Orthop Relat Res. 1997;(337):27-41.

89. Oetgen ME, Yue JJ, la Torre JJ, Bertagnoli R. Does vertebral endplate morphology influence outcomes in lumbar total disc arthroplasty? Part II: clinical and radiographic results as evaluated utilizing the Vertebral Endplate Yue-Bertagnoli (VEYBR) classification. SAS J. 2008;2(2):101-106.

90. Yue JJ, Oetgen ME, la Torre JJ, Bertagnoli R. Does vertebral endplate morphology influence outcomes in lumbar disc arthroplasty? Part I: an initial assessment of a novel classification system of lumbar endplate morphology. SAS J. 2008;2(1):16-22.

91. Bertagnoli R, Yue JJ, Kershaw T, et al. Lumbar total disc arthroplasty utilizing the ProDisc prosthesis in smokers versus nonsmokers: a prospective study with 2-year minimum follow-up. Spine (Phila Pa 1976). 2006;31(9):992-997.

92. Bertagnoli R, Yue JJ, Fenk-Mayer A, Eerulkar J, Emerson JW. Treatment of symptomatic adjacent-segment degeneration after lumbar fusion with total disc arthroplasty by using the prodisc prosthesis: a prospective study with 2-year minimum follow up. J Neurosurg Spine. 2006;4(2):91-97.

93. Bertagnoli R, Yue JJ, Nanieva R, et al. Lumbar total disc arthroplasty in patients older than 60 years of age: a prospective study of the ProDisc prosthesis with 2-year minimum follow-up period. J Neurosurg Spine. 2006;4(2):85-90.

94. Bertagnoli R, Yue JJ, Shah RV, et al. The treatment of disabling multilevel lumbar discogenic low back pain with total disc arthroplasty utilizing the ProDisc prosthesis: a prospective study with 2-year minimum follow-up. Spine (Phila Pa 1976). 2005;30(19):2192-2199.

95. Bertagnoli R, Kumar S. Indications for full prosthetic 
disc arthroplasty: a correlation of clinical outcome against a variety of indications. Eur Spine J. 2001;11(Suppl 2):S131-S136.

96. Guyer RD, Siddiqui S, Zigler JE, et al. Lumbar spinal arthroplasty: analysis of one center's twenty best and twenty worst clinical outcomes. Spine (Phila Pa 1976). 2008;33(23):2566-2569.

97. Devin CJ, Myers TG, Kang JD. Chronic failure of a lumbar total disc replacement with osteolysis. Report of a case with nineteen-year follow-up. J Bone Joint Surg Am. 2008;90(10):2230-2234.

98. Lu SB, Wang QY, Hai Y, Su QJ, Kang N, Zhang CS. [Total lumbar disc replacement with SB Charite III prosthesis: Chinese experience with more than two years follow-up]. Zhonghua Wai Ke Za Zhi. 2008;46(5):342-345.

99. Alpizar-Aguirre A, Mireles-Cano JN, Rosales-Olivares M, Miramontes-Martinez V, Reyes-Sanchez A. [Clinical and radiological follow-up of Nubac disc prosthesis. Preliminary report]. Cir Cir. 2008;76(4):317-321.

100. Morales JF, Palacios JL, Soriano JC. [Twelve cases of total arthroplasty of lumbar disc. Preliminary results at 6 months]. Acta Orthop Mex. 2008;22(2):97-102.

101. Leahy M, Zigler JE, Ohnmeiss DD, Rashbaum RF, Sachs BL. Comparison of results of total disc replacement in postdiscectomy patients versus patients with no previous lumbar surgery. Spine (Phila Pa 1976). 2008;33(15):16901693; discussion 1694-1695.

102. Geisler FH, Guyer RD, Blumenthal SL, et al. Effect of previous surgery on clinical outcome following 1-level lumbar arthroplasty. J Neurosurg Spine. 2008;8(2):108-114.

103. Guyer RD, Geisler FH, Blumenthal SL, McAfee PC, Mullin BB. Effect of age on clinical and radiographic outcomes and adverse events following 1-level lumbar arthroplasty after a minimum 2-year follow-up. J Neurosurg Spine. 2008;8(2):101107.

104. Levin DA, Bendo JA, Quirno M, Errico T, Goldstein J, Spivak J. Comparative charge analysis of one- and two-level lumbar total disc arthroplasty versus circumferential lumbar fusion. Spine (Phila Pa 1976). 2007;32(25):2905-2909.

105. Bendo JA, Quirno M, Errico T, Spivak JM, Goldstein J. A comparison of two retroperitoneal surgical approaches for total disc arthroplasty of the lumbar spine. Spine (Phila Pa 1976). 2008;33(2):205-209.

106. Karatoprak O, Aydogan M, Ozturk C, Mirzanli C, Tezer M, Hamzaoglu A. [Total disc prosthesis for painful degenerative lumbar disc disease]. Acta Orthop Traumatol Turc. 2007;41(4):281-285.

107. Geisler FH, Guyer RD, Blumenthal SL, et al. Patient selection for lumbar arthroplasty and arthrodesis: the effect of revision surgery in a controlled, multicenter, randomized study. J Neurosurg Spine. 2008;8(1):13-16.

108. Cunningham BW, McAfee PC, Geisler FH, et al. Distribution of in vivo and in vitro range of motion following 1level arthroplasty with the CHARITE artificial disc compared with fusion. J Neurosurg Spine. 2008;8(1):7-12.

109. Park SA, Ordway N, Fayyazi A, Fredrickson B, Yuan HA. Measurement of paradoxical and coupled motions following lumbar total disc replacement. SAS J. 2008;2(3):137-139.

110. Marshman LA, Trewhella M, Friesem T, Rampersaud YR, Le Huec JC, Krishna M. The accuracy and validity of "routine" X-rays in estimating lumbar disc arthroplasty placement. Spine (Phila Pa 1976). 2007;32(23):E661-E666.

111. Siepe CJ, Korge A, Grochulla F, Mehren C, Mayer HM. Analysis of post-operative pain patterns following total lumbar disc replacement: results from fluoroscopically guided spine infiltrations. Eur Spine J. 2008;17(1):44-56.

112. Zeilstra DJ. [Complains after implantation of a disc prosthesis for low back pain]. Ned Tijdschr Geneeskd. 2007;151(39):2179-2180; author reply 2180-2171.

113. Punt IM, Visser VM, van Rhijn LW, et al. Complications and reoperations of the SB Charite lumbar disc prosthesis: experience in 75 patients. Eur Spine J. 2008;17(1):36-43.

114. Hannibal M, Thomas DJ, Low J, Hsu KY, Zucherman J. ProDisc-L total disc replacement: a comparison of 1level versus 2-level arthroplasty patients with a minimum 2-year follow-up. Spine 2007;32(21):2322-2326.

115. van Ooij A, Schurink GW, Oner FC, Verbout AJ. [Findings in 67 patients with recurrent or persistent symptoms after implantation of a disc prosthesis for low back pain]. Ned Tijdschr Geneeskd. 2007;151(28):1577-1584.

116. Marshman LA, Friesem T, Rampersaud YR, Le Huec JC, Krishna M, Reddy GR. Significantly improved lumbar arthroplasty placement using image guidance: technical note. Spine (Phila Pa 1976). 2007;32(18):2027-2030.

117. Nowakowski A, Cabaj M, Tobjasz F, Kubaszewski L. Disc arthroplasty in the lumbar and cervical spine. Ortop Traumatol Reahbil. 2004;6(3):254-258.

118. Marshman LA, Friesem T, Rampersaud YR, Le Huec JC, Krishna M. Subsidence and malplacement with the Oblique Maverick Lumbar Disc Arthroplasty: technical note. Spine J. 2008;8(4):650-655.

119. Zigler J, Delamarter R, Spivak JM, et al. Results of the prospective, randomized, multicenter Food and Drug Administration investigational device exemption study of the ProDisc-L total disc replacement versus circumferential fusion for the treatment of 1-level degenerative disc disease. Spine (Phila Pa 1976). 2007;32(11):1155-1162; discussion 1163.

120. Rognsvag T, Strand LI, Skouen JS. [Pain and functional ability in patients with total disc replacement in the lumbar spine]. Tidsskr Nor Laegeforen. 2007;127(9):1188-1191.

121. Leary SP, Regan JJ, Lanman TH, Wagner WH. Revision and explantation strategies involving the CHARITE lumbar artificial disc replacement. Spine (Phila Pa 1976). 2007;32(9):1001-1011.

122. Siepe CJ, Mayer HM, Heinz-Leisenheimer M, Korge A. Total lumbar disc replacement: different results for different levels. Spine (Phila Pa 1976). 2007;32(7):782-790.

123. David T. Long-term results of one-level lumbar arthroplasty: minimum 10-year follow-up of the CHARITE artificial disc in 106 patients. Spine (Phila Pa 1976). 2007;32(6):661-666.

124. Auerbach JD, Wills BP, McIntosh TC, Balderston RA. Evaluation of spinal kinematics following lumbar total disc replacement and circumferential fusion using in vivo fluoroscopy. Spine (Phila Pa 1976).2007;32(5):527-536.

125. Zeh A, Planert M, Siegert G, Lattke P, Held A, Hein W. Release of cobalt and chromium ions into the serum following implantation of the metal-on-metal Maverick-type artificial lumbar disc (Medtronic Sofamor Danek). Spine (Phila Pa 1976).2007:32(3):348-352. 
126. van Ooij A, Kurtz SM, Stessels F, Noten H, van Rhijn L. Polyethylene wear debris and long-term clinical failure of the Charite disc prosthesis: a study of 4 patients. Spine (Phila $\mathrm{Pa}$ 1976). 2007;32(2):223-229.

127. Siepe CJ, Wiechert K, Khattab MF, Korge A, Mayer HM. Total lumbar disc replacement in athletes: clinical results, return to sport and athletic performance. Eur Spine J. 2007;16(7):1001-1013.

128. Kurtz SM, van Ooij A, Ross R, et al. Polyethylene wear and rim fracture in total disc arthroplasty. Spine $J$. 2007;7(1):12-21.

129. Geisler FH. Surgical treatment for discogenic lowback pain: lumbar arthroplasty results in superior pain reduction and disability level improvement compared with lumbar fusion. SAS J. 2007;1(1):12-19.

130. Zigler JE, Sachs BL, Rashbaum RF, Ohnmeiss DD. Two- to 3-year follow-up of prodisc-1: results from a prospective randomized trial of arthroplasty versus fusion. SAS J. 2007;1(2):63-67.

131. Blumenthal SL, Guyer RD, Geisler FH, McAfee PC, Regan JJ. The first 18 months following food and drug administration approval of lumbar total disc replacement in the United States: reported adverse events outside an investigational device exemption study environment. SAS J. 2007;1(1):8-11.

132. Tournier C, Aunoble S, Le Huec JC, et al. Total disc arthroplasty: consequences for sagittal balance and lumbar spine movement. Eur Spine J. 2007;16(3):411-421.

133. Chung SS, Lee CS, Kang CS, Kim SH. The effect of lumbar total disc replacement on the spinopelvic alignment and range of motion of the lumbar spine. J Spinal Discord Tech. 2006;19(5):307-311.

134. Huang RC, Tropiano P, Marnay T, Girardi FP, Lim MR, Cammisa FP Jr. Range of motion and adjacent level degeneration after lumbar total disc replacement. Spine $J$. 2006;6(3):242-247.

135. Tropiano P, Huang RC, Girardi FP, Cammisa FP Jr, Marnay T. Lumbar total disc replacement. Surgical technique. J Bone Joint Surg Am. 2006;88(Suppl 1, Pt 1):50-64.

136. SariAli el H, Lemaire JP, Pascal-Mousselard H, Carrier H, Skalli W. In vivo study of the kinematics in axial rotation of the lumbar spine after total intervertebral disc replacement: long-term results: a 10-14 years follow up evaluation. Eur Spine J. 2006;15(10):1501-1510.

137. Neal CJ, Rosner MK, Kuklo TR. Magnetic resonance imaging evaluation of adjacent segments after disc arthroplasty. J Neurosurg Spine. 2005;3(5):342-347.

138. Putzier M, Funk JF, Schneider SV, et al. Charite total disc replacement-clinical and radiographical results after an average follow-up of 17 years. Eur Spine J. 2006;15(2):183-195.

139. Bertagnoli R, Yue JJ, Shah RV, et al. The treatment of disabling single-level lumbar discogenic low back pain with total disc arthroplasty utilizing the Prodisc prosthesis: a prospective study with 2-year minimum follow-up. Spine (Phila Pa 1976). 2005;30(9):2230-2236.

140. Shim CS, Lee S, Maeng DH, Lee SH. Vertical split fracture of the vertebral body following total disc replacement using ProDisc: report of two cases. J Spinal Discord Tech. 2005;18(5):465-469.

141. Trouillier H, Kern P, Refior HJ, Muller-Gerbl M. A prospective morphological study of facet joint integrity following intervertebral disc replacement with the CHARITE Artificial Disc. Eur Spine J. 2006;15(2):174-182.

142. Cakir B, Richter M, Puhl W, Schmidt R. Reliability of motion measurements after total disc replacement: the spike and the fin method. Eur Spine J. 2006;15(2):165-173.

143. Lemaire JP, Carrier H, Sariali el H, Skalli W, Lavaste F. Clinical and radiological outcomes with the Charite artificial disc: a 10-year minimum follow-up. J Spinal Discord Tech. 2005;18(2):353-359.

144. Huang RC, Girardi FP, Cammisa FP Jr, Lim MR, Tropiano P, Marnay T. Correlation between range of motion and outcome after lumbar total disc replacement: 8.6-year follow-up. Spine (Phila Pa 1976). 2005;30(12):1407-1411.

145. Le Huec JC, Mathews H, Basso Y, et al. Clinical results of Maverick lumbar total disc replacement: two-year prospective follow-up. Orthop Clin North Am. 2005;36(3):315322.

146. Mathew $\mathrm{P}$, Blackman $\mathrm{M}$, Redla S, Hussein AA. Bilateral pedicle fractures following anterior dislocation of the polyethylene inlay of a ProDisc artificial disc replacement: a case report of an unusual complication. Spine (Phila Pa 1976). 2005;30(11):E311-E314.

147. Le Huec JC, Basso Y, Aunoble S, Friesem T, Bruno MB. Influence of facet and posterior muscle degeneration on clinical results of lumbar total disc replacement: two-year follow-up. J Spinal Discord Tech. 2005;18(3):219-223.

148. Le Huec J, Basso Y, Mathews H, et al. The effect of single-level, total disc arthroplasty on sagittal balance parameters: a prospective study. Eur Spine J. 2005;14(5):480-486.

149. David T. Revision of a Charite artificial disc 9.5 years in vivo to a new Charite artificial disc: case report and explant analysis. Eur Spine J. 2005;14(5):507-511.

150. Zigler JE. Lumbar spine arthroplasty using the ProDisc II. Spine J. 2004;4(6 Suppl):260s-267s.

151. Guyer RD, McAfee PC, Hochschuler SH, et al. Prospective randomized study of the Charite artificial disc: data from two investigational centers. Spine J. 2004:4(6 Suppl):252s-259s.

152. Delamarter RB, Fribourg DM, Kanim LE, Bae H. ProDisc artificial total lumbar disc replacement: introduction and early results from the United States clinical trial. Spine (Phila Pa 1976). 2003;28(20):S167-S175.

153. Zigler JE. Clinical results with ProDisc: European experience and U.S. investigation device exemption study. Spine (Phila Pa 1976). 2003;28(20):S163-S166.

154. McAfee PC, Fedder IL, Saiedy S, Shucosky EM, Cunningham BW. Experimental design of total disk replacement-experience with a prospective randomized study of the SB Charite. Spine (Phila Pa 1976). 2003;28(20):S153-S162.

155. McAfee PC, Fedder IL, Saiedy S, Shucosky EM, Cunningham BW. SB Charite disc replacement: report of 60 prospective randomized cases in a US center. $J$ Spinal Discord Tech. 2003;16(4):424-433.

156. Kim WJ, Lee SH, Kim SS, Lee C. Treatment of juxtafusional degeneration with artificial disc replacement (ADR): preliminary results of an ongoing prospective study. $J$ Spinal Discord Tech. 2003;16(4):390-397.

157. van Ooij A, Oner FC, Verbout AJ. Complications of artificial disc replacement: a report of 27 patients with the SB Charite disc. J Spinal Discord Tech. 2003;16(4):369-383.

158. Tropiano P, Huang RC, Girardi FP, Marnay T. 
Lumbar disc replacement: preliminary results with ProDisc II after a minimum follow-up period of 1 year. $J$ Spinal Discord Tech. 2003;16(4):362-368.

159. Zigler JE, Burd TA, Vialle EN, Sachs BL, Rashbaum RF, Ohnmeiss DD. Lumbar spine arthroplasty: early results using the ProDisc II: a prospective randomized trial of arthroplasty versus fusion. J Spinal Discord Tech. 2003;16(4):352-361.

160. Hochschuler SH, Ohnmeiss DD, Guyer RD, Blumenthal SL. Artificial disc: preliminary results of a prospective study in the United States. Eur Spine J. 2002;11(Suppl 2):S106S110.

161. Khoueir P, Wang MY. Posterior dynamic stabilization as a salvage procedure for lumbar facet degeneration following total disc arthroplasty: case report. $S A S J$. 2007;1(4):143-146.

162. Kafer W, Clessienne CB, Daxle M, Kocak T, Reichel $\mathrm{H}$, Cakir B. Posterior component impingement after lumbar total disc replacement: a radiographic analysis of 66 ProDisc-L prostheses in 56 patients. Spine (Phila Pa 1976). 2008;33(22):2444-2449.

163. Warachit P. Results of Charite artificial lumbar disc replacement: experience in 43 Thais. J Med Assoc Thai. 2008;91(8):1212-1217.

164. Yaszay B, Bendo JA, Goldstein JA, Quirno M, Spivak JM, Errico TJ. Effect of intervertebral disc height on postoperative motion and outcomes after ProDisc-L lumbar disc replacement. Spine (Phila Pa 1976). 2008;33(5):508-512; discussion 513.

165. Sasso RC, Foulk DM, Hahn M. Prospective, randomized trial of metal-on-metal artificial lumbar disc replacement: initial results for treatment of discogenic pain. Spine (Phila Pa 1976). 2008;33(2):123-131.

166. Hahnle UR, Sliwa K, de Villiers M, Weinberg IR, Sweet BM, Candy GP. Is degenerative spondylolisthesis a contraindication for total disc replacement? kineflex lumbar disc replacement in 7 patients with 24-month follow-up. $S A S J$. 2008;2(2):92-100.

167. Ordway NR, Fayyazi AH, Abjornson C, et al. Twelve-month follow-up of lumbar spine range of motion following intervertebral disc replacement using radiostereometric analysis. $S A S J$. 2008;2(1):9-15.

168. Kim DH, Ryu KS, Kim MK, Park CK. Factors influencing segmental range of motion after lumbar total disc replacement using the ProDisc II prosthesis. J Neurosurg Spine. 2007;7(2):131-138.

169. McAfee P, Khoo LT, Pimenta L, et al. Treatment of lumbar spinal stenosis with a total posterior arthroplasty prosthesis: implant description, surgical technique, and a prospective report on 29 patients. Neurosurg Focus. 2007;22(1):E13.

170. Holt RT, Majd ME, Isaza JE, et al. Complications of lumbar artificial disc replacement compared to fusion: results from the prospective, randomized, multicenter us food and drug administration investigational device exemption study of the charite artificial disc. SAS J. 2007;1(1):20-27.

171. Regan JJ, McAfee PC, Blumenthal SL, et al. Evaluation of surgical volume and the early experience with lumbar total disc replacement as part of the investigational device exemption study of the Charite Artificial Disc. Spine (Phila Pa 1976). 2006;31(19):2270-2276.
172. McAfee PC, Geisler FH, Saiedy SS, et al. Revisability of the CHARITE artificial disc replacement: analysis of 688 patients enrolled in the U.S. IDE study of the CHARITE Artificial Disc. Spine (Phila Pa 1976). 2006;31():1217-1226.

173. Huang DS, Liang AJ, Ye W, et al. [The risk factors and preventive strategies of heterotopic ossification after artificial disc replacement in lumbar spine]. Zhonghua Wai Ke Za Zhi. 2006;44(11):242-245.

174. Cakir B, Richter M, Kafer W, Puhl W, Schmidt R. The impact of total lumbar disc replacement on segmental and total lumbar lordosis. Clin Biomech (Bristol, Avon). 2005;20(4):357-364.

175. Geisler FH, Blumenthal SL, Guyer RD, et al. Neurological complications of lumbar artificial disc replacement and comparison of clinical results with those related to lumbar arthrodesis in the literature: results of a multicenter, prospective, randomized investigational device exemption study of Charite intervertebral disc. Invited submission from the Joint Section Meeting on Disorders of the Spine and Peripheral Nerves, March 2004. J Neurosurg Spine. 2004;1(2):143-154.

176. Hopf C, Heeckt H, Beske C. [Indication, biomechanics and early results of artificial disk replacement]. Z Orthop Ihre Grenzgeb. 2004;142(2):153-158.

177. Blumenthal SL, Ohnmeiss DD, Guyer RD, Hochschuler SH. Prospective study evaluating total disc replacement: preliminary results. J Spinal Discord Tech. 2003;16(5):450-454.

178. Huang RC, Girardi FP, Cammisa FP Jr, Tropiano P, Marnay T. Long-term flexion-extension range of motion of the prodisc total disc replacement. J Spinal Discord Tech. 2003;16(5):435-440.

179. Caspi I, Levinkopf M, Nerubay J. Results of lumbar disk prosthesis after a follow-up period of 48 months. Isr Med Assoc J. 2003;5(1):9-11.

180. Hopf C, Heeckt H, Beske C. [Disc replacement with the SB Charite endoposthesis - experience, preliminary results and comments after 35 prospectively performed operations]. $Z$ Orthop Ihre Grenzgeb. 2007;140(5):485-491.

181. Zeegers WS, Bohnen LM, Laaper M, Verhaegen MJ. Artificial disc replacement with the modular type SB Charite III: 2-year results in 50 prospectively studied patients. Eur Spine J. 1999;8(3):210-217.

182. Park CK, Ryu KS, Jee WH. Degenerative changes of discs and facet joints in lumbar total disc replacement using ProDisc II: minimum two-year follow-up. Spine (Phila $\mathrm{Pa}$ 1976). 2008;33(16):1755-1761.

183. Siepe CJ, Mayer HM, Wiechert K, Korge A. Clinical results of total lumbar disc replacement with ProDisc II: threeyear results for different indications. Spine (Phila Pa 1976). 2006;31(17):1923-1932.

184. Patel VV, Andrews C, Pradhan BB, et al. Computed tomography assessment of the accuracy of in vivo placement of artificial discs in the lumbar spine including radiographic and clinical consequences. Spine (Phila Pa 1976). 2006;31(8):948953.

185. Cakir B, Schmidt R, Huch K, Puhl W, Richter M. [Sagittal alignment and segmental range of motion after total disc replacement of the lumbar spine]. Z Orthop Ihre Grenzgeb. 2004;142(8):159-165.

186. Mayer HM, Wiechert K. Microsurgical anterior approaches to the lumbar spine for interbody fusion and total disc replacement. Neurosurgery. 2002;51(5 Supple):S159-S165. 
187. Shim CS, Lee SH, Shin HD, et al. CHARITE versus ProDisc: a comparative study of a minimum 3-year follow-up. Spine (Phila Pa 1976). 2007;32(9):1012-1018.

188. Zigler JE, Ohnmeiss DD. Comparison of 2-level versus 1-level total disc replacement: results from a prospective FDA-regulated trial. SAS J. 2008;2(3):140-144.

189. McAfee PC, Cunningham BW, Devine J, Williams E, $\mathrm{Yu}$-Yahiro J. Classification of heterotopic ossification (HO) in artificial disk replacement. J Spinal Discord Tech. 2003;16(4):384-389.

190. Buttner-Janz K. Letter to the Editor concerning "Charite total disc replacement: clinical and radiographical results after an average follow-up of 17 years" (M. Putzier et al.). Eur Spine J. 2006;15(4):510-513; author reply 518-520, discussion 521-512.

191. Buttner-Janz K. Optimal minimally traumatic approach for the SB Charite Artificial Disc. Eur Spine $J$. 2002;11(Suppl 2):S111-S114.

192. Buttner-Janz K, Hahn S, Schikora K, Link HD. [Basic principles of successful implantation of the SB Charite model LINK intervertebral disk endoprosthesis]. Orthopade. 2002;31(5):441-453.

193. Bertagnoli R, Zigler J, Karg A, Voigt S. Complications and strategies for revision surgery in total disc replacement. Orthop Clin North Am. 2005;36(3):389-395.

194. Bertagnoli R, Tropiano P, Zigler J, Karg A, Voigt S. Hybrid constructs. Orthop Clin North Am. 2005;36(3):379-388.

195. Bertagnoli R, Karg A, Voigt S. Lumbar partial disc replacement. Orthop Clin North Am. 2005;36(3):341-347.

196. Blumenthal SL, Ohnmeiss DD, Guyer R, et al. Artificial intervertebral discs and beyond: a North American Spine Society Annual Meeting symposium. Spine $J$. 2002;2(6):460-463.

197. Bertagnoli R, Vazquez RJ. The Anterolateral TransPsoatic Approach (ALPA): a new technique for implanting prosthetic disc-nucleus devices. J Spinal Discord Tech. 2003;16(4):398-404.

198. Konovalov NA, Shevelev IN, Kungurtsev VV, Zelenkov PV, Nazarenko AG. [Replacement of lumbosacral intervertebral disks using artificial prostheses: surgical tactics and technique]. Zh Vopr Neirokhir Im N N Burdenko. 2008;(3):2530; discussion 30-21.

199. Patel VV, Estes S, Lindley EM, Burger E. Lumbar spinal fusion versus anterior lumbar disc replacement: the financial implications. J Spinal Discord Tech. 2008;21(7):473476.

200. Wiedenhofer B, Ewerbeck V, Suda AJ, Carstens C. [Current short- and long-term results of lumbar disc replacement: update 2008]. Chirurg. 2008:79(10):937-943.

201. Resnick DK, Watters WC. Lumbar disc arthroplasty: a critical review. Clin Neurosurg. 2007;54:83-87.

202. Errico TJ. Looking ahead: what long-term outcomes can we expect from spinal devices for degenerative disc disease. J Long Term Eff Med Implants. 2008;18(4):309-319.

203. Marshman LA, Friesem T, Rampersaud YR, Le Huec JC, Krishna M, Reddy GR. Lumbar total disc arthroplasty: coronal midline definition and optimal TDA placement. $J$ Long Term Eff Med Implants. 2008;18(4):303-307.

204. Schulte TL, Lerner T, Hackenberg L, Liljenqvist U, Bullmann V. Acquired spondylolysis after implantation of a lumbar ProDisc II prosthesis: case report and review of the literature. Spine (Phila Pa 1976). 2007;32(22):E645-E648.

205. Orr RD, Postak PD, Rosca M, Greenwald AS The current state of cervical and lumbar spinal disc arthroplasty. $J$ Bone Joint Surg Am. 2007;89(Suppl 3)70-75.

206. Madonia-Barr JR. Lumbar ADR: a triumph of technology over reason? JAAPA. 2007;20(8):30-33.

207. Wilson-MacDonald J, Boeree N. Controversial topics in surgery: degenerative disc disease: disc replacement. For. Ann $R$ Coll Surg Engl. 2007;89(1):6-11.

208. Pimenta L, Diaz RC, Guerrero LG. Charite lumbar artificial disc retrieval: use of a lateral minimally invasive technique. Technical note. J Neurosurg Spine. 2006;5(6):556561.

209. Lin EL, Wang JC. Total disk arthroplasty. J Am Acad Orthop Surg. 2006;14(13):705-714.

210. An HS. Artificial disc replacement: progress or hype? Am J Orthop (Belle Mead NJ). 2006;35(9):405.

211. Bao QB, Yuan HA. Artificial disc technology. Neurosurgical focus 2000;9(4):e14.

212. Baur-Melnyk A, Birkenmaier C, Reiser MF. [Lumbar disc arthroplasty: indications, biomechanics, types, and radiological criteria]. Radiologe. 2006;46(9):768, 770-768.

213. Snell BE, Maiman DJ. Decompression, arthrodesis, and arthroplasty: decision making in the surgical treatment of lumbar disc disease. Clin Neurosurg. 2005;52:271-278.

214. Kulkarni AG, Diwan AD. Prosthetic lumbar disc replacement for degenerative disc disease. Neurol India. 2005;53(4):499-505.

215. Link HD. Letter to the Editor concerning "Charite total disc replacement: clinical and radiographical results after an average follow-up of 17 years" (M. Putzier et al.). Eur Spine J. 2006;15(4):514-517; author reply 518-520, discussion 521512.

216. Petersilge CA. Lumbar disc replacement. Seminars in musculoskeletal radiology 2006;10(1):22-29.

217. Stieber JR, Donald GD, 3rd. Early failure of lumbar disc replacement: case report and review of the literature. $J$ Spinal Discord Tech. 2006;19(1):55-60.

218. Aryan HE, Acosta FL Jr, Ames CP. The ProDisc artificial disc: insertion technique. Neurosurg Clin $N \mathrm{Am}$. 2005;16(4):651-656, vii.

219. Aryan HE, Acosta FL Jr, Ames CP. The Charite Artificial Disc: insertion technique. Neurosurg Clin $N \mathrm{Am}$. 2005:16(4)637-650, vii.

220. German JW, Foley KT. Disc arthroplasty in the management of the painful lumbar motion segment. Spine (Phila Pa 1976).2005;30(16 Suppl):S60-67.

221. Mayer HM. Total lumbar disc replacement. $J$ Bone Joint Surg Br. 2005;87(8)1029-1037.

222. Schulte TL, Bullmann V, Lerner $\mathrm{T}$, Halm HF, Liljenqvist U, Hackenberg L. [Lumbar disc arthroplasty. Established technique or experimental procedure?]. Orthopade. 2005;34(8):801-813.

223. Regan JJ. Clinical results of charite lumbar total disc replacement. Orthop Clin North Am. 2005;36(3):323-340.

224. Frelinghuysen P, Huang RC, Girardi FP, Cammisa FP Jr. Lumbar total disc replacement part I: rationale, biomechanics, and implant types. Orthop Clin North Am. 2005;36(3):293-299. 
225. Errico TJ. Lumbar disc arthroplasty. Clin Orthop Relat Res. 2005;(435):106-117.

226. Traynelis VC. Spinal arthroplasty. Neurosurgical Focus. 2002;13(2):E10.

227. Shuff C, An HS. Artificial disc replacement: the new solution for discogenic low back pain? Am J Orthop (Belle Mead NJ). 2005;34(1):8-12.

228. Gamradt SC, Wang JC Lumbar disc arthroplasty. Spine J. 2005;5():95-103.

229. Anderson PA, Rouleau JP. Intervertebral disc arthroplasty. Spine (Phila Pa 1976). 2004;29(1):2779-2786.

230. Singh K, Vaccaro AR, Albert TJ. Assessing the potential impact of total disc arthroplasty on surgeon practice patterns in North America. Spine J. 2004;4(6 Suppl):195s-201s.

231. Santos EG, Polly DW Jr, Mehbod AA, Saleh KJ. Disc arthroplasty: lessons learned from total joint arthroplasty. Spine J. 2004;4(6 Suppl):182s-189s.

232. McAfee PC. The indications for lumbar and cervical disc replacement. Spine J. 2004;4(6 Suppl):177s-181s.

233. Errico TJ. Why a mechanical disc? Spine $J$. 2004;4():151s-157s.

234. McAfee PC, Polly DW Jr, Cunningham B, et al. Clinical summary statement. Spine (Phila Pa 1976). 2003;28(6 Suppl):S196-S198.

235. Polly DW Jr. Adapting innovative motion-preserving technology to spinal surgical practice: what should we expect to happen? Spine (Phila Pa 1976). 2003;28(20):S104-S109.

236. de Kleuver M, Oner FC, Jacobs WC. Total disc replacement for chronic low back pain: background and a systematic review of the literature. Eur Spine J. 2003;12(2):108116.

237. Mayer HM, Korge, A. Non-fusion technology in degenerative lumbar spinal disorders: facts, questions, challenges. Eur Spine J. 2002;11(Suppl 2):S85-S91.

238. Korovessis PG. Re: Sasso RC, Foulk DM, Hahn M. Prospective, randomized trial of metal-on-metal artificial lumbar disc replacement: initial results for treatment of discogenic pain. Spine 2008;33:123-31. Spine (Phila Pa 1976). 2008;33(16):1812.

239. Zhang N, Yin G. [Advancement in repair and reconstruction of the spine and spine cord injury]. Zhongguo Xiu Fu Chong Jian Wai Ke Za Zhi. 2008;22(4):385-389.

240. ECRI Institute. Artificial intevertebral disc replacement for lumbar degenerative disc disease: what's the state of the evidence? OR Manager. 2007;23(9):suppl 1-4 following 16.

241. BlueCross BlueShield Association. Artificial lumbar disc replacement. Technol Eval Cent Assess Program Exec Summ. 2007;22(2)1-3.

242. Shedid D, Ugokwe KT, Benzel EC. Lumbar total disc replacement compared with spinal fusion: treatment choice and evaluation of outcome. Nat Clin Pract Neurol. 2005;1(1):4-5.

243. Freeman BJ, Davenport, J. Total disc replacement in the lumbar spine: a systematic review of the literature. Eur Spine J. 2006;15(Suppl 3)S439-S447.

244. Herkowitz HN. Total disc replacement with the CHARITE artificial disc was as effective as lumbar interbody fusion. J Bone Joint Surg Am. 2006;88(5):1168.

245. Guyer RD, Ohnmeiss DD. Intervertebral disc prostheses. Spine (Phila Pa 1976). 2003;28(15 Suppl):S15-S23.

246. Mayer HM, Wiechert K, Korge A, Qose I. Minimally invasive total disc replacement: surgical technique and preliminary clinical results. Eur Spine J. 2002;11(Suppl 2)S124-S130.

247. Health Quality Ontario. Artificial discs for lumbar and cervical degenerative disc disease -update: an evidencebased analysis. Ont Health Technol Assess Ser. 2006;6(10)1-98.

248. Mayer HM. [Degenerative disorders of the lumbar spine Total disc replacement as an alternative to lumbar fusion?]. Orthopade. 2005;34(10):1007-1014, 1016-1020.

249. Fairbank J. Re: Zigler J, Delamarter R, Spivak J, et al. Results of the prospective, randomized, multicenter Food and Drug Administration investigational device exemption study of the ProDisc-L total disc replacement versus circumferential fusion for the treatment of 1-level degenerative disc disease. Spine. 2007;32:1155-62. Spine (Phila Pa 1976). 2007;32(25):2929-2930; author reply 2930-2921.

250. Burger EL. Lumbar disk replacement: restoring mobility. Orthopedics. 2004;27(4):386-388.

251. Harrop JS, Youssef JA, Maltenfort M, et al. Lumbar adjacent segment degeneration and disease after arthrodesis and total disc arthroplasty. Spine (Phila Pa 1976). 2008;33(15):1701-1707.

252. Guyer RD, Tromanhauser SG, Regan JJ. An economic model of one-level lumbar arthroplasty versus fusion. Spine J. 2007;7(5):558-562.

253. Rousseau MA, Bradford DS, Bertagnoli R, Hu SS, Lotz JC. Disc arthroplasty design influences intervertebral kinematics and facet forces. Spine J. 2006;6(3):258-266.

254. Bertagnoli R, Sabatino CT, Edwards JT, Gontarz GA, Prewett A, Parsons JR. Mechanical testing of a novel hydrogel nucleus replacement implant. Spine J. 2005;5(6):672681.

255. Galbusera F, Bellini CM, Zweig T, et al. Design concepts in lumbar total disc arthroplasty. Eur Spine J. 2008;17(12):1635-1650.

256. Gstoettner M, Heider D, Liebensteiner M, Bach CM. Footprint mismatch in lumbar total disc arthroplasty. Eur Spine J. 2008;17(11):1470-1475.

257. Petilon J, Hardenbrook M, Sukovich W. The effect of parallax on intraoperative positioning of the Charite artificial disc. J Spinal Discord Tech. 2008;21(6):422-429.

258. Kosmopoulos V, Stafylas K, McManus J, Schizas C. Radiographic total disc replacement angle measurement accuracy using the Oxford Cobbometer: precision and bias. Eur Spine J. 2008;17(8):1066-1072.

259. Dmitriev AE, Gill NW, Kuklo TR, Rosner MK. Effect of multilevel lumbar disc arthroplasty on the operativeand adjacent-level kinematics and intradiscal pressures: an in vitro human cadaveric assessment. Spine J. 2008;8(6):918-925.

260. Shaheen A, Shepherd DE. Lubrication regimes in lumbar total disc arthroplasty. Proc Inst Mech Eng $H$. 2007;221(6)621-627.

261. Wenzel SA, Shepherd DE. Contact stresses in lumbar total disc arthroplasty. Biomed Mater Eng. 2007;17(3):169-173.

262. Lim MR, Loder RT, Huang RC, et al. Measurement error of lumbar total disc replacement range of motion. Spine (Phila Pa 1976). 2006;31(10):E291-E297.

263. Wang JC, Haid RW Jr. Advances in biomaterials that led to the artificial disc. Clin Neurosurg. 2005;52:163-167.

264. Kotani Y, Cunningham BW, Abumi K, et al. Multidirectional flexibility analysis of anterior and posterior 
lumbar artificial disc reconstruction: in vitro human cadaveric spine model. Eur Spine J. 2006;15(10):1511-1520.

265. Denoziere G, Ku DN. Biomechanical comparison between fusion of two vertebrae and implantation of an artificial intervertebral disc. J Biomech. 2006;39(4):766-775.

266. Crawford NR. Biomechanics of lumbar arthroplasty. Neurosurg Clin N Am. 2005;16(4):595-602, v.

267. Hu X, Li K. [Stress changes of upper lumbar facet joint after discectomy and artificial disc replacement]. Zhongguo Xiu Fu Chong Jian Wai Ke Za Zhi. 2005;19(6):427-430.

268. Huang RC, Wright TM, Panjabi MM, Lipman JD. Biomechanics of nonfusion implants. Orthop Clin North Am. 2005;36(3):271-280.

269. DiAngelo DJ, Foley KT. An improved biomechanical testing protocol for evaluating spinal arthroplasty and motion preservation devices in a multilevel human cadaveric cervical model. Neurosurg Focus. 2004;17(3):E4.

270. Chang BS, Brown PR, Sieber A, Valdevit A, Tateno K, Kostuik JP. Evaluation of the biological response of wear debris. Spine J. 2004;4(6 Suppl):239s-244s.

271. Taksali S, Grauer JN, Vaccaro AR. Material considerations for intervertebral disc replacement implants. Spine $J$. 2004;4(6 Suppl):231s-238s.

272. Cunningham BW. Basic scientific considerations in total disc arthroplasty. Spine J. 2004;4(6 Suppl):219s-230s.

273. Buttermann GR, Beaubien BP. Stiffness of prosthetic nucleus determines stiffness of reconstructed lumbar calf disc. Spine J. 2004;4(3):265-274.

274. Hallab N, Link HD, McAfee PC. Biomaterial optimization in total disc arthroplasty. Spine (Phila Pa 1976). 2003;28(20):S139-S152.

275. Cunningham BW, Dmitriev AE, Hu N, McAfee PC. General principles of total disc replacement arthroplasty: seventeen cases in a nonhuman primate model. Spine (Phila Pa 1976). 2003;28(20):S118-S124.

276. Cunningham BW, Gordon JD, Dmitriev AE, Hu N, McAfee PC. Biomechanical evaluation of total disc replacement arthroplasty: an in vitro human cadaveric model. Spine (Phila Pa 1976).I 2003;28(20):S110-S117.

277. Huang RC, Girardi FP, Cammisa FP Jr, Wright TM. The implications of constraint in lumbar total disc replacement. J Spinal Discord Tech. 2003;16(4):412-417.

278. LeHuec JC, Kiaer T, Friesem T, Mathews H, Liu M, Eisermann L. Shock absorption in lumbar disc prosthesis: a preliminary mechanical study. J Spinal Discord Tech. 2003;16(4):346-351.

279. Cunningham BW, Lowery GL, Serhan HA, et al. Total disc replacement arthroplasty using the AcroFlex lumbar disc: a non-human primate model. Eur Spine J. 2002;11(Suppl 2):S115-S123.

280. Ge L, Li KH. [Biomechanical analysis of artificial intervertebral disc in a 3-dimensional finite-element model]. Zhong Nan Da Xue Xue Bao Yi Xue Ban. 2008;33(11):10411046.

281. Weisskopf M, Ohnsorge JA, Martini F, Niethard FU, Birnbaum K. [Influence of inlay height on motion characteristics of lumbar segments in total disc replacement]. Z Orthop Unfall 2008;146(4):452-457.

282. Nunley PD, Jawahar A, Mukherjee DP, et al. Comparison of pressure effects on adjacent disk levels after 2level lumbar constructs: fusion, hybrid, and total disk replacement. Surgical neurology 2008;70(3):247-251; discussion 251.

283. Lee JL, Billi F, Sangiorgio SN, et al. Wear of an experimental metal-on-metal artificial disc for the lumbar spine. Spine (Phila Pa 1976). 2008;33(6):597-606.

284. Wilke HJ, Schmidt H, Werner K, Schmolz W, Drumm J. Biomechanical evaluation of a new total posterior-element replacement system. Spine (Phila Pa 1976). 2006;31(24):2790 2796; discussion 2797.

285. Lei GH, Li KH, Liu SL, Lin FY, Li LJ, Song XC. [Stability of lumbar spine after artificial disc replacement] Zhong Nan Da Xue Xиe Bao Yi Xue Ban. 2006;31(5):728-731.

286. Liu J, Ebraheim NA, Haman SP, et al. Effect of the increase in the height of lumbar disc space on facet joint articulation area in sagittal plane. Spine (Phila Pa 1976). 2006;31(7):E198-E202.

287. O'Leary P, Nicolakis M, Lorenz MA, et al. Response of Charite total disc replacement under physiologic loads: prosthesis component motion patterns. Spine J. 2005;5(6):590 599.

288. Rohlmann A, Zander T, Bergmann G. Effect of total disc replacement with ProDisc on intersegmental rotation of the lumbar spine. Spine (Phila Pa 1976). 2005;30(7):738-743.

289. Kotani Y, Abumi K, Shikinami Y, et al. Two-year observation of artificial intervertebral disc replacement: results after supplemental ultra-high strength bioresorbable spinal stabilization. J Neurosurg. 2004;100(4 Suppl Spine):337-342.

290. Takahata M, Kotani Y, Abumi K, et al. Bone ingrowth fixation of artificial intervertebral disc consisting of bioceramic-coated three-dimensional fabric. Spine (Phila $\mathrm{Pa}$ 1976). 2003;28(7):637-644; discussion 644.

291. Kotani Y, Abumi K, Shikinami Y, et al. Artificial intervertebral disc replacement using bioactive three-dimensional fabric: design, development, and preliminary animal study. Spine (Phila Pa 1976). 2002;27(9):929-935; discussion 935-926.

292. Kadoya K, Kotani Y, Abumi K, et al. Biomechanical and morphologic evaluation of a three-dimensional fabric sheep artificial intervertebral disc: in vitro and in vivo analysis. Spine (Phila Pa 1976). 2001;26(14):1562-1569.

293. Dooris AP, Goel VK, Grosland NM, Gilbertson LG, Wilder DG. Load-sharing between anterior and posterior elements in a lumbar motion segment implanted with an artificial disc. Spine (Phila Pa 1976). 2001;26(6):E122-E129.

294. Rundell SA, Auerbach JD, Balderston RA, Kurtz SM. Total disc replacement positioning affects facet contact forces and vertebral body strains. Spine (Phila Pa 1976). 2008;33(23):2510-2517.

295. McAfee PC, Cunningham BW, Orbegoso CM, Sefter JC, Dmitriev AE, Fedder IL. Analysis of porous ingrowth in intervertebral disc prostheses: a nonhuman primate model. Spine (Phila Pa 1976). 2004;28():332-340.

296. McAfee PC, Cunningham BW, Hayes V, et al. Biomechanical analysis of rotational motions after disc arthroplasty: implications for patients with adult deformities. Spine (Phila Pa 1976). 2006;31(4):S152-S60.

297. Panjabi M, Malcolmson G, Teng E, Tominaga Y, Henderson G, Serhan H. Hybrid testing of lumbar CHARITE discs versus fusions. Spine (Phila Pa 1976). 2007;32():959-966; discussion 967.

298. Panjabi M, Henderson G, Abjornson C, Yue J. 
Multidirectional testing of one- and two-level ProDisc-L versus simulated fusions. Spine (Phila Pa 1976). 2007;32():1311-1319.

299. Bao QB, Songer M, Pimenta L, et al. Nubac disc arthroplasty: preclinical studies and preliminary safety and efficacy evaluations. SAS J. 2007;1(9):36-45.

300. Fraser RD, Ross ER, Lowery GL, Freeman BJ, Dolan M. AcroFlex design and results. Spine J. 2004;4(6 Suppl):245s-251s.

301. Laouissat F, Scemama C, Delecrin J. Does the type of sagittal spinal shape influence the clinical results of lumbar disc arthroplasty? Orthop Traumatol Surg Res. 2016;102(6):765-768.

302. Sun W, Lu S, Hai Y, et al. [An imaging study on effect of total artificial disc replacement on lumbar sagittal alignment]. Zhonghua Wai Ke Za Zhi. 2016;54(2):104-107.

303. Wagner R, Iprenburg M, Telfeian AE. Transforaminal endoscopic decompression of a postoperative dislocated bone fragment after a 2-level lumbar total disc replacement: case report. Neurosurg Focus. 2016;40(2):E8.

304. Eliasberg CD, Kelly MP, Ajiboye RM, SooHoo NF. Complications and rates of subsequent lumbar surgery following lumbar total disc arthroplasty and lumbar fusion. Spine (Phila Pa 1976). 2016;41(2):173-181.

305. Svedmark P, Berg S, Noz ME, et al. A New CT Method for assessing 3D movements in lumbar facet joints and vertebrae in patients before and after TDR. Biomed Res Int. 2015;2015:260703.

306. Rischke B, Zimmers KB, Smith E. Viscoelastic Disc arthroplasty provides superior back and leg pain relief in patients with lumbar disc degeneration compared to anterior lumbar interbody fusion. Int J Spine Surg. 2015;9:26.

307. Jackson KL, Hire JM, Jacobs JM, Key CC, DeVine JG. Heterotopic ossification causing radiculopathy after lumbar total disc arthroplasty. Asian Spine J. 2015;9(3):456-460.

308. Schatz C, Ritter-Lang K, Gossel L, Dressler N. Comparison of single-level and multiple-level outcomes of total disc arthroplasty: 24-month results. Int J Spine Surg. 2015;9:14.

309. Assaker R, Ritter-Lang K, Vardon D, et al. Maverick total disc replacement in a real-world patient population: a prospective, multicentre, observational study. Eur Spine J. 2015;24(9):2047-2055.

310. Lee WT, Liu G, Thambiah J, Wong HK. Clinical outcomes of single-level lumbar artificial disc replacement compared with transforaminal lumbar interbody fusion in an Asian population. Singapore Med J. 2015;56(4):208-211.

311. Glukhikh DL. [The outcomes of arthroplasty in degenerative lesions in the lumbar spine]. Zh Vopr Neirokhir Im N N Burdenko. 2015;79(1):68-74.

312. Lu SB, Hai Y, Kong C, et al. An 11-year minimum follow-up of the Charite III lumbar disc replacement for the treatment of symptomatic degenerative disc disease. Eur Spine J. 2015;24(9):2056-2064.

313. Tohmeh AG, Smith WD. Lumbar total disc replacement by less invasive lateral approach: a report of results from two centers in the US IDE clinical trial of the XL TDR(R) device. Eur Spine J. 2015;24(Suppl 3):331-338.

314. Mostofi K. Total disc arthroplasty for treating lumbar degenerative disc disease. Asian Spine J. 2015;9(1):59-64.

315. Barrett RS, Lichtwark GA, Armstrong C, Barber L, Scott-Young M, Hall RM. Fluoroscopic assessment of lumbar total disc replacement kinematics during walking. Spine (Phila Pa 1976). 2015;40(7):436-442.
316. Laouissat F, Allain J, Delecrin J. Intraoperative determination of lumbar prosthesis endplate lordotic angulation to improve motion. Orthop Traumatol Surg Res. 2015;101(1):109-113.

317. Trincat S, Edgard-Rosa G, Geneste G, Marnay T. Two-level lumbar total disc replacement: functional outcomes and segmental motion after 4 years. Orthop Traumatol Surg Res. 2015;101(1):17-21.

318. Lu S, Kong C, Hai Y, et al. Prospective clinical and radiographic results of Activ L total disk replacement at 1- to 3year follow-up. J Spinal Discord Tech. 2015;28(9):E544-E550.

319. Veruva SY, Lanman TH, Isaza JE, MacDonald DW, Kurtz SM, Steinbeck MJ. UHMWPE wear debris and tissue reactions are reduced for contemporary designs of lumbar total disc replacements. Clin Orthop Relat Res. 2015;473(3):987-998.

320. Ciarpaglini R, Otten P, Sutter P, Duy VQ, Gautier E, Maestretti G. Sacroiliac joint syndrome 10 years after lumbar arthroplasty: the importance of spinopelvic alignment. Eur Spine J. 2014;23(Suppl 6):720-724.

321. Guyer RD, Pettine K, Roh JS, et al. Comparison of 2 lumbar total disc replacements: results of a prospective, randomized, controlled, multicenter Food and Drug Administration trial with 24-month follow-up. Spine (Phila Pa 1976). 2014;39(12):925-931.

322. Alahmadi H, Deutsch H. Outcome of salvage lumbar fusion after lumbar arthroplasty. Asian Spine J. 2014;8(1):1318.

323. Siepe CJ, Heider F, Wiechert K, Hitzl W, Ishak B, Mayer MH. Mid- to long-term results of total lumbar disc replacement: a prospective analysis with 5- to 10-year followup. Spine J. 2014;14(8):1417-1431.

324. Lazennec JY, Even J, Skalli W, Rakover JP, Brusson A, Rousseau MA. Clinical outcomes, radiologic kinematics, and effects on sagittal balance of the $6 \mathrm{df}$ LP-ESP lumbar disc prosthesis. Spine J. 2014;14(9):1914-1920.

325. Aghayev E, Elfering A, Schizas C, Mannion AF. Factor analysis of the North American Spine Society outcome assessment instrument: a study based on a spine registry of patients treated with lumbar and cervical disc arthroplasty. Spine J. 2014;14(6):916-924.

326. Strube P, Hoff EK, Schurings M, et al. Parameters influencing the outcome after total disc replacement at the lumbosacral junction. Part 2: distraction and posterior translation lead to clinical failure after a mean follow-up of 5 years. Eur Spine J. 2013;22(10):2279-2287.

327. Skold C, Tropp H, Berg S. Five-year follow-up of total disc replacement compared to fusion: a randomized controlled trial. Eur Spine J. 2013;22(10):2288-2295.

328. Jang SH, Lee HY, Cho JY, Lee SH. Solid fusion after lumbosacral arthroplasty. World J Orthop. 2013;4(3):157-160.

329. O'Shaughnessy J, Roy JF, Descarreaux M. Changes in flexion-relaxation phenomenon and lumbo-pelvic kinematics following lumbar disc replacement surgery. J Neuroeng Rehabil. 2013;10:72.

330. Gragnaniello C, Seex KA, Eisermann LG, Claydon $\mathrm{MH}$, Malham GM. Early postoperative dislocation of the anterior Maverick lumbar disc prosthesis: report of 2 cases. $J$ Neurosurg Spine. 2013;19(2):191-196.

331. Boss OL, Tomasi SO, Baurle B, Sgier F, Hausmann ON. Lumbar total disc replacement: correlation of clinical 
outcome and radiological parameters. Acta Neurochir (Wien) 2013;155(10):1923-1930.

332. Yue J, Zhang K, Bai HX, et al. A comparison of patients who have undergone 1-Level versus 2-Level ProDisc arthroplasty: a prospective study with minimum of 5-year follow-up. Spine (Phila Pa 1976). 2013;38(14):1194-1198.

333. Daxle M, Kocak T, Lattig F, Reichel H, Cakir B. [Adjacent segment movement after monosegmental total disc replacement and monosegmental fusion of segments L4/5]. Orthopade. 2013;42(2):81-89.

334. Meir AR, Freeman BJ, Fraser RD, Fowler SM. Tenyear survival and clinical outcome of the AcroFlex lumbar disc replacement for the treatment of symptomatic disc degeneration. Spine J. 2013;13(1):13-21.

335. Zarate-Kalfopulos B, Bran-Garcia M, Rosales-Olivarez LM, et al. [Comparison of three types of lumbar total disc arthroplasty. Four-year minimum follow-up]. Acta Ortop Mex. 2012;26(2):91-95.

336. Johnsen LG, Brinckmann P, Hellum C, Rossvoll I, Leivseth G. Segmental mobility, disc height and patientreported outcomes after surgery for degenerative disc disease: a prospective randomised trial comparing disc replacement and multidisciplinary rehabilitation. Bone Joint J. 2013;95-B(1):8189.

337. Shin MH, Ryu KS, Hur JW, Kim JS, Park CK. Association of facet tropism and progressive facet arthrosis after lumbar total disc replacement using ProDisc-L. Eur Spine J. 2013;22(8):1717-1722.

338. Kasliwal MK, Deutsch H. Lumbar disc replacement in adolescents: An initial experience in two cases. $J$ Pediatr Neruosci 2012;7(2):129-132.

339. Burkus JK, Dryer RF, Peloza JH. Retrograde ejaculation following single-level anterior lumbar surgery with or without recombinant human bone morphogenetic protein-2 in 5 randomized controlled trials: clinical article. J Neurosurg Spine. 2013;18(2):112-121.

340. Gornet MF, Burkus JK, Harper ML, Chan FW, Skipor AK, Jacobs JJ. Prospective study on serum metal levels in patients with metal-on-metal lumbar disc arthroplasty. Eur Spine J. 2013;22(4):741-746.

341. Zigler JE, Glenn J, Delamarter RB. Five-year adjacent-level degenerative changes in patients with single-level disease treated using lumbar total disc replacement with ProDisc-L versus circumferential fusion. J Neurosurg Spine. 2012;17(6):504-511.

342. Flouzat-Lachaniette $\mathrm{CH}$, Delblond W, Poignard A, Allain J. Analysis of intraoperative difficulties and management of operative complications in revision anterior exposure of the lumbar spine: a report of 25 consecutive cases. Eur Spine J. 2013;22(4):766-774.

343. Zigler JE, Delamarter RB. Five-year results of the prospective, randomized, multicenter, Food and Drug Administration investigational device exemption study of the ProDiscL total disc replacement versus circumferential arthrodesis for the treatment of single-level degenerative disc disease. $J$ Neurosurg Spine. 2013;17(6):493-501.

344. Flouzat-Lachaniette $\mathrm{CH}$, Guidon J, Allain J, Poignard A. An uncommon case of Mycoplasma hominis infection after total disc replacement. Eur Spine J. 2013;22(Suppl 3)S394398.

345. Jones CW, Smitham P, Walsh WR. Relationship of surgical accuracy and clinical outcomes in Charite lumbar disc replacement. Orthop Surg. 2013;4(3):145-155.

346. Hellum C, Berg L, Gjertsen O, et al. Adjacent level degeneration and facet arthropathy after disc prosthesis surgery or rehabilitation in patients with chronic low back pain and degenerative disc: second report of a randomized study. Spine (Phila Pa 1976). 2012;37(25):2063-2073.

347. Siepe CJ, Heider F, Haas E, et al. Influence of lumbar intervertebral disc degeneration on the outcome of total lumbar disc replacement: a prospective clinical, histological, X-ray and MRI investigation. Eur Spine J. 2012;21(11):2287-2299.

348. Lebl DR, Cammisa FP, Girardi FP, Wright T, Abjornson C. In vivo functional performance of failed Prodisc-L devices: retrieval analysis of lumbar total disc replacements. Spine (Phila Pa 1976). 2012;37(19):E1209-1217.

349. Lee CS, Lee DH, Hwang CJ, Kim H, Noh H. The effect of a mismatched center of rotation on the clinical outcomes and flexion-extension range of motion: lumbar total disk replacement using mobidisc at a 5.5-year follow-up. $J$ Spinal Discord Tech. 2014;27(3):148-153.

350. Edgard-Rosa G, Geneste G, Negre G, Marnay T. Midline anterior approach from the right side to the lumbar spine for interbody fusion and total disc replacement: a new mobilization technique of the vena cava. Spine (Phila Pa 1976). 2013;37(9):E562-569.

351. Lindley EM, McBeth ZL, Henry SE, et al. Retrograde ejaculation after anterior lumbar spine surgery. Spine (Phila Pa 1976). 2012;37(20):1785-1789.

352. Aghayev E, Henning J, Munting E, Diel P, Moulin P, Roder C. Comparative effectiveness research across two spine registries. Eur Spine J. 2012;21(8):1640-1647.

353. Matejka J, Zeman J, Matejka T, Nepras P, Belatka J. [Lumbar total disc replacement. Short-term results]. Acta Chir Orthop Traumatol Cech. 2012;79(1):37-40.

354. Austen S, Punt IM, Cleutjens JP, et al. Clinical, radiological, histological and retrieval findings of Activ-L and Mobidisc total disc replacements: a study of two patients. Eur Spine J. 2012;21(Suppl 4)S513-520.

355. Rainey S, Blumenthal SL, Zigler JE, Guyer RD, Ohnmeiss DD. Analysis of adjacent segment reoperation after lumbar total disc replacement. Int J Spine Surg. 2012;6:140 144.

356. Lindley EM, Patti BN, Taylor M, Burger EL, Patel VV. Lumbar artificial disc replacement in Ehlers-Danlos syndrome: A case report and discussion of clinical management. Int J Spine Surg. 2012;6:124-129.

357. Sullivan HG, Bertagnoli R, Nigogosyan MA, et al. Prevention of vertebral body-splitting fractures after multilevel ProDisc-L implantation. Int J Spine Surg. 2012;6:93-102.

358. Sullivan HG, Bobenmoyer RL, Boland KM, et al. Physical capability outcomes after total disc replacement with ProDisc-L. Int J Spine Surg. 2012;6:43-48.

359. Marchi L, Oliveira L, Coutinho E, Pimenta L. The importance of the anterior longitudinal ligament in lumbar disc arthroplasty: 36-Month follow-up experience in extreme lateral total disc replacement. Int J Spine Surg. 2012;6:18-23.

360. Yue JJ, Telles C, Schlosser TP, Hermenau S, Ramachandran R, Long WD, 3rd. Do presence and location of annular tear influence clinical outcome after lumbar total disc arthroplasty? A prospective 1-year follow-up study. Int $J$ Spine Surg. 2012;6:13-17. 
361. Zweig T, Hemmeler C, Aghayev E, Melloh M, Etter $\mathrm{C}$, Roder C. Influence of preoperative nucleus pulposus status and radiculopathy on outcomes in mono-segmental lumbar total disc replacement: results from a nationwide registry. $B M C$ Musculoskelet Disord. 2011;12:275.

362. Van de Kelft E, Verguts L. Clinical outcome of monosegmental total disc replacement for lumbar disc disease with ball-and-socket prosthesis (Maverick): prospective study with four-year follow-up. World Neurosurg. 2012;78(3-4)355363.

363. Bassani R, Sinigaglia A, Lamartina C. Video-assisted minimally invasive lumbar total disc replacement. Eur Spine J. 2011;20(12):2282-2283.

364. Markwalder TM, Wenger M, Marbacher S. A 6.5year follow-up of 14 patients who underwent ProDisc total disc arthroplasty for combined long-standing degenerative lumbar disc disease and recent disc herniation. J Clin Neurosci. 2011;18(12):1677-1681.

365. Cabraja M, Schmeding M, Koch A, Podrabsky P, Kroppenstedt S. Delayed formation of a devastating granulomatous process after metal-on-metal lumbar disc arthroplasty. Spine (Phila Pa 1976). 2012;37(13):E809-813.

366. Zahradnik V, Kashyap VS. Alternative management of iliac vein injury during anterior lumbar spine exposure. Ann Vasc Surg. 2012;26(2)277.e15-277.e18.

367. Berg S, Tropp HT, Leivseth G. Disc height and motion patterns in the lumbar spine in patients operated with total disc replacement or fusion for discogenic back pain. Results from a randomized controlled trial. Spine $J$. 2011;11(11):991-998.

368. Glenn JS, Yaker J, Guyer RD, Ohnmeiss DD. Anterior discectomy and total disc replacement for three patients with multiple recurrent lumbar disc herniations. Spine J. 2011;11(9):e1-e6.

369. Park CK, Ryu KS, Lee KY, Lee HJ. Clinical outcome of lumbar total disc replacement using ProDisc-L in degenerative disc disease: minimum 5-year follow-up results at a single institute. Spine (Phila Pa 1976). 2012;37(8):672-677.

370. Pellet N, Aunoble S, Meyrat R, Rigal J, Le Huec JC. Sagittal balance parameters influence indications for lumbar disc arthroplasty or ALIF. Eur Spine J. 2011;20(Suppl 5):647662.

371. Bisseling P, Zeilstra DJ, Hol AM, van Susante JL. Metal ion levels in patients with a lumbar metal-on-metal total disc replacement: should we be concerned? J Bone Joint Surg Br. 2011;93():949-954.

372. Kasliwal MK, Deutsch H. Effect of total lumbar disc replacement on lumbosacral lordosis. J Spinal Discord Tech. 2012;25(7):370-373.

373. Zweig T, Aghayev E, Melloh M, Dietrich D, Roder C. Influence of preoperative leg pain and radiculopathy on outcomes in mono-segmental lumbar total disc replacement: results from a nationwide registry. Eur Spine J. 2012;21(Suppl 6):S729-736.

374. Birkenmaier C, Boszczyk B, Baur-Melnyk A, Wegener B, Jansson V. Intravertebral neotrabecularization as an expression of focal load transfer by a keel-design lumbar total disc arthroplasty. Arch Orthop Trauma Surg. 2011;13(11):11481-1484.

375. Gornet MF, Burkus JK, Dryer RF, Peloza JH. Lumbar disc arthroplasty with Maverick disc versus stand- alone interbody fusion: a prospective, randomized, controlled, multicenter investigational device exemption trial. Spine (Phila Pa 1976). 2011;36(25):E1600-1611.

376. Delamarter R, Zigler JE, Balderston RA, Cammisa FP, Goldstein JA, Spivak JM. Prospective, randomized, multicenter Food and Drug Administration investigational device exemption study of the ProDisc-L total disc replacement compared with circumferential arthrodesis for the treatment of two-level lumbar degenerative disc disease: results at twentyfour months. J Bone Joint Surg Am. 2011;93(8):705-715.

377. Punt IM, Austen S, Cleutjens JP, et al. Are periprosthetic tissue reactions observed after revision of total disc replacement comparable to the reactions observed after total hip or knee revision surgery? Spine (Phila Pa 1976). 2012;37(2):150-159.

378. Knoeller SM, Ehmer M, Kleinmann B, Wolter T. CRPS I following artificial disc surgery: case report and review of the literature. Eur Spine J. 2013;20(Suppl 2):S278-S283.

379. Robinson ES, Lindley EM, Gonzalez P, et al. Piriformis syndrome versus radiculopathy following lumbar artificial disc replacement. Spine (Phila Pa 1976). 2011;36(4):E282-E287.

380. Guyer RD, Shellock J, MacLennan B, et al. Early failure of metal-on-metal artificial disc prostheses associated with lymphocytic reaction: diagnosis and treatment experience in four cases. Spine (Phila Pa 1976). 2011;36(7):E492-497.

381. Blondel B, Tropiano P, Gaudart J, Huang RC, Marnay T. Clinical results of lumbar total disc arthroplasty in accordance with Modic signs, with a 2-year-minimum followup. Spine (Phila Pa 1976). 2011;36(26):2309-2315.

382. Liu YC, Xia Q, Zhang JD, et al. [Effect of intervertebral position on range of motion after artificial lumbar total disc replacement and clinical management]. Zhonghua Yi Xue Za Zhi. 2010;90(39):2750-2754.

383. Delecrin J, Allain J, Beaurain J, et al. Effects of lumbar artificial disc design on intervertebral mobility: in vivo comparison between mobile-core and fixed-core. Eur Spine J. 2012;21(Suppl 5):S630-640.

384. Ogon M, Tuschel A. [Keel-based lumbar total disk replacement: Prodisc-L and Prodisc-O]. Oper Orthop Traumatol. 2010;22(5-6):593-607.

385. Mehren C, Korge A, Siepe C, Grochulla F, Mayer HM. [Minimal invasive anterior midline approach to L2-L5]. Oper Orthop Traumatol. 2010;22(5-6):573-581.

386. Katsimihas M, Bailey CS, Issa K, et al. Prospective clinical and radiographic results of CHARITE III artificial total disc arthroplasty at 2- to 7-year follow-up: a Canadian experience. Can J Surg. 2010;53(6):408-4145.

387. Eskander MS, Onyedika, II, Eskander JP, Connolly PJ, Eck JC, Lapinsky A. Revision strategy for posterior extrusion of the CHARITE polyethylene core. Spine (Phila $P a$ 1976). 2010;35(24):E1430-E1434.

388. Petilon J, Roth J, Hardenbrook M. Results of lumbar total disc arthroplasty in military personnel. J Spinal Discord Tech. 2011;24(5):297-301.

389. Jehan S, Elsayed S, Webb J, Boszczyk B. L5-S1 disc replacement after two previous fusion surgeries for scoliosis. Eur Spine J. 2011;20(5):669-673.

390. Daxle M, Kafer W, Kocak T, Reichel H, Cakir B. [Perioperative morbidity in lumbar disc replacement]. Z Orthop Unfall. 2010;148(4):448-452. 
391. Aghayev E, Roder C, Zweig T, Etter C, Schwarzenbach O. Benchmarking in the SWISSspine registry: results of 52 Dynardi lumbar total disc replacements compared with the data pool of 431 other lumbar disc prostheses. Eur Spine $J$. 2010;19(12):2190-2199.

392. Park SJ, Kang KJ, Shin SK, Chung SS, Lee CS. Heterotopic ossification following lumbar total disc replacement. Int Orthop. 2011;35(8):1197-1201.

393. Tumialan LM, Ponton RP, Garvin A, Gluf WM. Arthroplasty in the military: a preliminary experience with ProDisc-C and ProDisc-L. Neurosurg Focus. 2010;28(5):E18.

394. Deutsch H. The predictive value of the baseline Oswestry Disability Index in lumbar disc arthroplasty. Neurosurg Focus. 2010;28(6):E7.

395. Schmidt R, Obertacke U, Nothwang J, et al. The impact of implantation technique on frontal and sagittal alignment in total lumbar disc replacement: a comparison of anterior versus oblique implantation. Eur Spine $J$. 2010;19(9):1534-1539.

396. O’Shaughnessy J, Drolet M, Roy JF, Descarreaux M. Chiropractic management of patients post-disc arthroplasty: eight case reports. Chiropr Osteopat. 2010;18:7.

397. Ohnmeiss DD, Bodemer W, Zigler JE. Effect of adverse events on low back surgery outcome: twenty-fourmonth follow-up results from a Food And Drug Administration investigational device exemption trial. Spine (Phila $\mathrm{Pa}$ 1976). 2010;35(7):835-838

398. Kurtz SM, Lau E, Ianuzzi A, et al. National revision burden for lumbar total disc replacement in the United States: epidemiologic and economic perspectives. Spine (Phila $\mathrm{Pa}$ 1976). 2010;35(6):690-696.

399. Kerr EJ, Jawahar A, Kay S, Cavanaugh DA, Nunley PD. Implant design may influence delayed heterotopic ossification after total disk arthroplasty in lumbar spine. Surg Neurol. 2009;72(6):747-751; discussion 751.

400. Ching AC, Birkenmaier C, Hart RA. Short segment coronal plane deformity after two-level lumbar total disc replacement. Spine (Phila Pa 1976). 2010;35(1):44-50.

401. Mohapatra B, Kishen T, Loi KW, Diwan AD. Retroperitoneal lymphocele after lumbar total disc replacement: a case report and review of literature. SAS J. 2010;4(3):87-91.

402. Pimenta L, Springmuller R, Lee CK, Oliveira L, Roth SE, Ogilvie WF. Clinical performance of an elastomeric lumbar disc replacement: Minimum 12 months follow-up. SAS J. 2010;4(1):16-25.

403. Park SA, Ordway NR, Fayyazi AH, Fredrickson BE, Yuan HA. Comparison of Cobb technique, quantitative motion analysis, and radiostereometric analysis in measurement of segmental range of motions after lumbar total disc arthroplasty. J Spinal Discord Tech. 2009;22(8):602-609.

404. Spivak JM, Petrizzo AM. Revision of a lumbar disc arthroplasty following late infection. Eur Spine $J$. 2010;19(8):677-681.

405. Siepe CJ, Tepass A, Hitzl W, et al. Dynamics of improvement following total lumbar disc replacement: is the outcome predictable? Spine (Phila Pa 1976). 2009;34(23):25792586.

406. Auerbach JD, Jones KJ, Milby AH, Anakwenze OA, Balderston RA. Segmental contribution toward total lumbar range of motion in disc replacement and fusions: a comparison of operative and adjacent levels. Spine (Phila Pa 1976). 2009;34(23):2510-2517.

407. Aunoble S, Meyrat R, Al Sawad Y, Tournier C, Leijssen P, Le Huec JC. Hybrid construct for two levels disc disease in lumbar spine. Eur Spine J. 2010;19(2):290-296.

408. Berg S, Fritzell P, Tropp H. Sex life and sexual function in men and women before and after total disc replacement compared with posterior lumbar fusion. Spine J. 2009;9(12):987-994.

409. Gottfried ON, Brodke DS. Traumatic burst fracture in a patient with a lumbar artificial disc. J Neurosurg Spine. 2009;11(3):353-357.

410. de Maat GH, Punt IM, van Rhijn LW, Schurink GW, van Ooij A. Removal of the Charite lumbar artificial disc prosthesis: surgical technique. J Spinal Discord Tech. 2009;22(5):334-339.

411. Sinigaglia R, Bundy A, Costantini S, Nena U, Finocchiaro F, Monterumici DA. Comparison of single-level L4-L5 versus L5-S1 lumbar disc replacement: results and prognostic factors. Eur Spine J. 2009;18(Suppl 1):52-63.

412. Di Silvestre M, Bakaloudis G, Lolli F, Vommaro F, Parisini P. Two-level total lumbar disc replacement. Eur Spine J. 2009;18(Suppl 1):64-70.

413. Schluessmann E, Diel P, Aghayev E, Zweig T, Moulin P, Roder C. SWISSspine: a nationwide registry for health technology assessment of lumbar disc prostheses. Eur Spine J. 2009;18(6):851-861.

414. Punt IM, Cleutjens JP, de Bruin T, et al. Periprosthetic tissue reactions observed at revision of total intervertebral disc arthroplasty. Biomaterials. 2009;30(11):2079-2084.

415. Delecrin J, Allain J, Beaurain J, et al. Does core mobility of lumbar total disc arthroplasty influence sagittal and frontal intervertebral displacement? Radiologic comparison with fixed-core prosthesis. SAS J. 2009;3(3):91-99.

416. Geisler FH, McAfee PC, Banco RJ, et al. Prospective, randomized, multicenter FDA IDE study of charite artificial disc versus lumbar fusion: effect at 5-year follow-up of prior surgery and prior discectomy on clinical outcomes following lumbar arthroplasty. SAS J. 2009;3(1):17-25.

417. Rohan MX Jr, Ohnmeiss DD, Guyer RD, et al. Relationship between the length of time off work preoperatively and clinical outcome at 24-month follow-up in patients undergoing total disc replacement or fusion. Spine $J$. 2009;9(5):360-365.

418. Guyer RD, McAfee PC, Banco RJ, et al. Prospective, randomized, multicenter Food and Drug Administration investigational device exemption study of lumbar total disc replacement with the CHARITE artificial disc versus lumbar fusion: five-year follow-up. Spine J. 2009;9(5):374-386.

419. Veruva SY, Lanman TH, Isaza JE, Freeman TA, Kurtz SM, Steinbeck MJ. Periprosthetic UHMWPE wear debris induces inflammation, vascularization, and innervation after total disc replacement in the lumbar spine. Clin Orthop Relat Res. 2017;475(5):1369-1381.

420. Pimenta L, Marchi L, Amaral RA, et al. 342 Lumbar Total Disc Replacement by the Lateral Approach Up to 10Year Follow-up. Neurosurgery. 2016;63(Suppl 1):200-201.

421. De la Garza-Ramos R, Abt NB, Kerezoudis P, et al. Deep-wound and organ-space infection after surgery for degenerative spine disease: an analysis from 2006 to 2012. Neurol Res. 2016;38(2):117-123. 
422. Park SJ, Lee CS, Chung SS, Lee KH, Kim WS, Lee JY. Long-term outcomes following lumbar total disc replacement using ProDisc-II: average 10-year follow-up at a single institute. Spine (Phila Pa 1976). 2016;41(11):971-977.

423. Garcia R Jr, Yue JJ, Blumenthal S, et al. Lumbar total disc replacement for discogenic low back pain: two-year outcomes of the activL multicenter randomized controlled IDE clinical trial. Spine (Phila Pa 1976). 2015;40(24):18731881.

424. Berg S, Gillberg-Aronsson N. Clinical outcomes after treatment with disc prostheses in three lumbar segments compared to one- or two segments. Int J Spine Surg. 2015;9:49.

425. Strube P, Putzier M, Streitparth F, Hoff EK, Hartwig T. Postoperative posterior lumbar muscle changes and their relationship to segmental motion preservation or restriction: a randomized prospective study. J Neurosurg Spine. 2016;24(1):25-31.

426. Guyer RD, Pettine K, Roh JS, et al. Five-year followup of a prospective, randomized trial comparing two lumbar total disc replacements. Spine (Phila Pa 1976). 2016;41(1):3-8.

427. Green A, Gilbert P, Scott-Young M, Abbott A. Physiotherapeutic rehabilitation following lumbar total disc replacement: a retrospective study. Physiother Res Int. 2016;21(3):155-163.

428. Hoff EK, Strube P, Pumberger M, Zahn RK, Putzier M. ALIF and total disc replacement versus 2-level circumferential fusion with TLIF: a prospective, randomized, clinical and radiological trial. Eur Spine J. 2016;25(5):1558-1566.

429. Shin MH, Ryu KS, Rathi NK, Park CK. Segmental translation after lumbar total disc replacement using Prodisc$\mathrm{L}^{\circledR}$ : associated factors and relation to facet arthrosis. $J$ Neurosurg Sci. 2017;61(1):14-21.

430. Wang W, Liu S, He G, et al. Application of laparoscopic lumbar discectomy and artificial disc replacement: at least two years of follow-up. Spine (Phila Pa 1976). 2016;41(Suppl 19):B38-B43.

431. Li ZY, Han X, Ma S, Tian W. Effect of total lumbar disc replacement on the treatment of discogenic low lumbar pain: preliminary outcomes. Chin Med J (Engl). 2013;126(8):1504-1508.

432. Oktenoglu T, Ozer AF, Sasani M, Ataker Y, Gomleksiz C, Celebi I. Posterior transpedicular dynamic stabilization versus total disc replacement in the treatment of lumbar painful degenerative disc disease: a comparison of clinical results. Adv Orthop. 2013;2013:874090.

433. Quraishi NA, Konig M, Booker SJ, et al. Access related complications in anterior lumbar surgery performed by spinal surgeons. Eur Spine J. 2013;22(Suppl 1):S16-S20.

434. Mogannam A, Bianchi C, Chiriano J, et al. Effects of prior abdominal surgery, obesity, and lumbar spine level on anterior retroperitoneal exposure of the lumbar spine. Arch Surg. 2012;147(12);1130-1134.

435. Asha MJ, Choksey MS, Shad A, Roberts P, Imray C. The role of the vascular surgeon in anterior lumbar spine surgery. Br J Neurosurg. 2012;26(4):499-503.

436. Low JB, Du J, Zhang K, Yue JJ. ProDisc-L learning curve: 24-Month clinical and radiographic outcomes in 44 consecutive cases. Int J Spine Surg. 2012;6:184-189.

437. Magnussen LH. Surgery with disc prosthesis may produce better outcomes than multidisciplinary rehabilitation for patients with chronic low back pain. $J$ Physiother. 2011;57(4):257.

438. Scott-Young MN, Lee MJ, Nielsen DE, Magno CL, Kimlin KR, Mitchell EO. Clinical and radiological mid-term outcomes of lumbar single-level total disc replacement. Spine (Phila Pa 1976). 2011;43(2):105-113.

439. Kasliwal MK, Deutsch H. Anhidrosis after anterior retroperitoneal approach for L4-L5 artificial disc replacement. $J$ Clin Neurosci. 2011;18(7):990-991.

440. Canbulat N, Sasani M, Ataker Y, et al. A rehabilitation protocol for patients with lumbar degenerative disk disease treated with lumbar total disk replacement. Arch Phys Med Rehabil. 2011;92(4):670-676.

441. Pettine K, Hersh A. Kineflex lumbar artificial disc versus Charite lumbar total disc replacement for the treatment of degenerative disc disease: A randomized non-inferiority trial with minimum of 2 years' follow-up. SAS J. 2011;5(4):108-113.

442. Rischke B, Ross RS, Jollenbeck BA, Zimmers KB, Defibaugh ND. Preclinical and clinical experience with a viscoelastic total disc replacement. SAS J. 2011;5(4):97-107.

443. Cheng WK, Palmer DK, Jadhav V. Novel indication for posterior dynamic stabilization: Correction of disc tilt after lumbar total disc replacement. SAS J. 2011;5(2):44-47.

444. Pimenta L, Oliveira L, Schaffa T, Coutinho E, Marchi L. Lumbar total disc replacement from an extreme lateral approach: clinical experience with a minimum of 2 years' follow-up. J Neurosurg Spine. 2011;14(1):38-45.

445. Fritzell P, Berg S, Borgstrom F, Tullberg T, Tropp H. Cost effectiveness of disc prosthesis versus lumbar fusion in patients with chronic low back pain: randomized controlled trial with 2-year follow-up. Eur Spine J. 2011;20(7):1001-1011.

446. Siepe CJ, Zelenkov P, Sauri-Barraza JC, et al. The fate of facet joint and adjacent level disc degeneration following total lumbar disc replacement: a prospective clinical, X-ray, and magnetic resonance imaging investigation. Spine (Phila $\mathrm{Pa}$ 1976). 2010;35(22):1991-2003.

447. Berry MR, Peterson BG, Alander DH. A granulomatous mass surrounding a Maverick total disc replacement causing iliac vein occlusion and spinal stenosis: a case report. $J$ Bone Joint Surg Am. 2010;92(5):1242-1245.

448. Magaji SA, Debnath UK, Mehdian HS. Compartment syndrome of leg following total lumbar disc replacement via anterior retroperitoneal approach: a rare complication of anterior spinal surgery. Spine (Phila Pa 1976). 2010;35(3):E74E76.

449. Buttacavoli FA, Delamarter RB, Kanim LE. Cost comparison of patients with 3-level artificial total lumbar disc replacements versus 360 degrees fusion at 3 contiguous lumbar vertebral levels: an analysis of compassionate use at 1 site of the US investigational device exemption clinical trial. SAS J. 2010;4(4):107-114.

450. Rosen C, Kiester PD, Lee TQ. Lumbar disk replacement failures: review of 29 patients and rationale for revision. Orthopedics. 2009;32(8).

451. Cakir B, Schmidt R, Mattes T, Fraitzl CR, Reichel H, Kafer W. Index level mobility after total lumbar disc replacement: is it beneficial or detrimental? Spine (Phila $\mathrm{Pa}$ 1976). 2009;34(9):917-923.

452. Siepe CJ, Hitzl W, Meschede P, Sharma AK, Khattab MF, Mayer MH. Interdependence between disc space height, 
range of motion and clinical outcome in total lumbar disc replacement. Spine (Phila Pa 1976). 2009;34(9):904-916.

453. Berg S, Tullberg T, Branth B, Olerud C, Tropp H. Total disc replacement compared to lumbar fusion: a randomised controlled trial with 2-year follow-up. Eur Spine J. 2009;18(10):1512-1519.

454. Sasani M, Oktenoglu T, Tuncay K, Canbulat N, Carilli S, Ozer FA. Total disc replacement in the treatment of lumbar discogenic pain with disc herniation: a prospective clinical study. Turk Neurosurg. 2009;19(2):127-134.

455. Chen B, Akpolat YT, Williams P, Bergey D, Cheng WK. Survivorship and clinical outcomes after multi-level anterior lumbar reconstruction with stand-alone anterior lumbar interbody fusion or hybrid construct. J Clin Neurosci. 2016;28:7-11.

456. Harrison WD, Harrison DJ. The use of percutaneous lumbar fixation screws for bilateral pedicle fractures with an associated dislocation of a lumbar disc prosthesis. Case Rep Orthop. 2013;2013:676017.

457. Korge A, Siepe C, Mehren C, Mayer HM. [Minimally invasive anterior approaches to the lumbosacral junction]. Oper Orthop Traumatol. 2010;22(5-6):582-592.

458. Lee CS, Chung SS, Oh SK, You JW. Significance of angular mismatch between vertebral endplate and prosthetic endplate in lumbar total disc replacement. J Spinal Discord Tech. 2011;24(3):183-188.

459. Lazennec JY, Aaron A, Brusson A, Rakover JP, Rousseau MA. The LP-ESP ${ }^{\circledR}$ lumbar disc prosthesis with 6 degrees of freedom: development and 7 years of clinical experience. Eur J Orthop Surg Traumatol. 2013;23(2):131-143.

460. Pettine K, Ryu R, Techy F. Why lumbar artificial disc replacements (LADRs) fail. Clin Spine Surg. 2017;30(6):E743E747.

461. Hellum C, Johnsen LG, Storheim K, et al. Surgery with disc prosthesis versus rehabilitation in patients with low back pain and degenerative disc: two year follow-up of randomised study. BMJ. 2011;342:d2786.

462. Furunes H, Hellum C, Brox JI, et al. Lumbar total disc replacement: predictors for long-term outcome. Eur Spine J. 2018;27(3):709-718.

463. Park HJ, Lee CS, Chung SS, et al. Radiological and clinical long-term results of heterotopic ossification following lumbar total disc replacement [published online September 20, 2017. Spine J. https://doi.org/10.1016/j.spinee.2017.09.003.

464. Lu S, Sun S, Kong C, et al. Long-term clinical results following Charite III lumbar total disc replacement [published online September 1, 2017]. Spine J. https://doi.org/10.1016/j. spinee.2017.08.252.

465. Mattei TA, Beer J, Teles AR, Rehman AA, Aldag J, Dinh D. Clinical outcomes of total disc replacement versus anterior lumbar interbody fusion for surgical treatment of lumbar degenerative disc disease. Global Spine J. 2017;7(5):452459.

466. Phan K, Xu J, Maharaj MM, Mobbs RJ. Intraoperative navigation for accurate midline placement of anterior lumbar interbody fusion and total disc replacement prosthesis. J Spine Surg. 2017;3(2):228-232.

467. Wuertinger C, Annes RDA, Hitzl W, Siepe CJ. Motion preservation following total lumbar disc replacement at the lumbosacral junction: a prospective long-term clinical and radiographic investigation. Spine J. 2018;18(1):72-80.
468. Furunes H, Storheim K, Brox JI, et al. Total disc replacement versus multidisciplinary rehabilitation in patients with chronic low back pain and degenerative discs: 8-year follow-up of a randomized controlled multicenter trial. Spine $J$. 2017;17(10):1480-1488.

469. Plais N, Thevenot X, Cogniet A, Rigal J, Le Huec JC. Maverick total disc arthroplasty performs well at 10 years follow-up: a prospective study with HRQL and balance analysis. Eur Spine J. 2018;27(3):720-727.

470. Storheim K, Berg L, Hellum C, et al. Fat in the lumbar multifidus muscles - predictive value and change following disc prosthesis surgery and multidisciplinary rehabilitation in patients with chronic low back pain and degenerative disc: 2-year follow-up of a randomized trial. BMC Musculoskelet Disord. 2017;18(1):145.

471. Laugesen LA, Paulsen RT, Carreon L, Ernst C, Andersen MO. Patient-reported outcomes and revision rates at a mean follow-up of 10 years after lumbar total disc replacement. Spine (Phila Pa 1976). 2017;42(21):1657-1663.

472. Malham GM, Parker RM. Early experience with lateral lumbar total disc replacement: Utility, complications and revision strategies. J Clin Neurosci. 2017;39:176-183.

473. Laustsen AF, Bech-Azeddine R. Do Modic changes have an impact on clinical outcome in lumbar spine surgery? A systematic literature review. Eur Spine J. 2016;25(11):37353745 .

474. Andrieu K, Allain J, Longis PM, Steib JP, Beaurain J, Delecrin J. Comparison between total disc replacement and hybrid construct at two lumbar levels with minimum follow-up of two years. Orthop Traumatol Surg Res. 2017;103(1):39-43.

475. Bastien J, Lecomte Y, Willems S. A retrospective review of 345 patients with lumbar TDR in two years follow-up over 10 years of practice in one Belgian clinical center: results. Acta Orthop Belg. 2016;82(3):440-455.

476. Veruva SY, Lanman TH, Isaza JE, Freeman TA, Kurtz SM, Steinbeck MJ. Periprosthetic UHMWPE wear debris induces inflammation, vascularization, and innervation after total disc replacement in the lumbar spine. Clin Orthop Relat Res. 2017;475(5):1369-1381.

477. Shultz BN, Wilson AT, Ondeck NT, et al. Total disc arthroplasty and anterior interbody fusion in the lumbar spine have relatively few differences in readmission and short-term adverse events. Spine (Phila Pa 1976). 2018;43(1):E52-E59.

478. Scott-Young M, McEntee L, Schram B, Rathbone E, Hing W, Nielsen D. Concurrent use of lumbar total disc arthroplasty and anterior lumbar interbody fusion: the lumbar hybrid procedure for the treatment of multilevel symptomatic degenerative disc disease: a prospective study. Spine (Phila $\mathrm{Pa}$ 1976). 2018;15(2):E75-E81.

479. Clavel P, Ungureanu G, Catala I, Montes G, Malaga $\mathrm{X}$, Rios M. Health-related quality of life in patients undergoing lumbar total disc replacement: a comparison with the general population. Clin Neurol Neurosurg. 2017;160:119-124.

480. Lackey A, Phan K, Mobbs R. A systematic review and meta-analysis of outcomes in hybrid constructs for multilevel lumbar degenerative disc disease. J Clin Neurosci. 2016;34:23-29.

481. Vaccaro AR, Schroeder GD. Expression of concern. $J$ Spinal Discord Tech. 2015;28(9):E551.

482. Baliga S, Treon K, Craig NJ. Low back pain: current surgical approaches. Asian Spine J. 2015;9(4):645-657. 
483. Zigler J, Garcia R. ISASS Policy Statement-lumbar artificial disc. Int J Spine Surg. 2015;9:7.

484. Heider FC, Mayer HM, Siepe CJ. Lumbar disc replacement: update. J Neurosurg Sci. 2015;59(2):169-180.

485. Nie H, Chen G, Wang X, Zeng J. Comparison of total disc replacement with lumbar fusion: a meta-analysis of randomized controlled trials. J Coll Physicians Surg Pak. 2015;25(1):60-67.

486. Chopko B, Liu JC, Khan MK. Anatomic surgical management of chronic low back pain. Neuromodulation. 2014;17(Suppl 2):46-51.

487. Cecchinato R, Berjano P, Bassani R, Sinigaglia A, Lamartina C. How do interbody devices affect sagittal plane alignment. J Neurosurg Sci. 2014;58(2 Suppl 1):87-90.

488. Yoshihara H, Yoneoka D. National trends in the surgical treatment for lumbar degenerative disc disease: United States, 2000 to 2009. Spine J. 2015;15(2):265-271.

489. BlueCross BlueShield Association. Artificial lumbar disc arthroplasty. Technol Eval Cent Assess Program Exec Summ. 2014;28(7):1-3.

490. Saavedra-Pozo FM, Deusdara RA, Benzel EC. Adjacent segment disease perspective and review of the literature. Oschner J. 2014;14(1):78-83.

491. Zigler JE, Delamarter RB. Oswestry disability index. $J$ Neurosurg Spine. 2014;20(2):241-242.

492. Rao MJ, Cao SS. Artificial total disc replacement versus fusion for lumbar degenerative disc disease: a metaanalysis of randomized controlled trials. Arch Orthop Trauma Surg. 2014;134(2):149-158.

493. Lykissas MG, Aichmair A. Current concepts on spinal arthrodesis in degenerative disorders of the lumbar spine. World $J$ Clin Cases. 2013;1(1):4-12.

494. Fairbank JC. Oswestry disability index. J Neurosurg Spine. 2014;20(2):239-241.

495. Wang Q, Wang JC, Xiong CZ. Letter regarding article by Wei et al.: Comparison of artificial total disc replacement versus fusion for lumbar degenerative disc disease: a metaanalysis of randomised controlled trials. Int Orthop. 2014;38(1):211.

496. Liao G, Deng F, Yin X, Lin J. Comment on Wei et al.: Comparison of artificial total disc replacement versus fusion for lumbar degenerative disc disease: a meta-analysis of randomized controlled trials. Int Orthop. 2013;37(10):2107-2108.

497. Thavaneswaran P, Vandepeer M. Lumbar artificial intervertebral disc replacement: a systematic review. $A N Z J$ Surg. 2014;84(3):121-127.

498. Wei J, Song Y, Sun L, Lv C. Comparison of artificial total disc replacement versus fusion for lumbar degenerative disc disease: a meta-analysis of randomized controlled trials. Int Orthop. 2013;37(7):1315-1325.

499. Helgeson MD, Bevevino AJ, Hilibrand AS. Update on the evidence for adjacent segment degeneration and disease. Spine J. 2013;13(3):342-351.

500. Parkinson B, Goodall S, Thavaneswaran P. Costeffectiveness of lumbar artificial intervertebral disc replacement: driven by the choice of comparator. ANZ J Surg. 2013;83(9)669-675.

501. Tu TH, Zieacz JE, Mummaneni PV. Editorial: disc replacement or arthrodesis. J Neurosurg Spine. 2012;17(6):491; author response 492 .

502. Tu TH, Ziewacz JE, Mummaneni PV. Editorial: disc replacement versus fusion. J Neurosurg Spine. 2012;17(6):502; author response 503 .

503. Jacobs W, Van der Gaag NA, Tuschel A, et al. Total disc replacement for chronic back pain in the presence of disc degeneration. Cochrane Databse Syst Rev. 2012;CD008326.

504. Wang JC, Arnold PM, Hermsmeyer JT, Norvell DC. Do lumbar motion preserving devices reduce the risk of adjacent segment pathology compared with fusion surgery? A systematic review. Spine (Phila Pa 1976). 2012;37(22 Suppl):S133-S143.

505. Kovacs FM, Abraira V, Arana E, et al. Re: Blondel B, Tropiano P, Gaudart J, Huang RC, Marnay T. Clinical results of lumbar total disc arthroplasty in accordance with Modic signs, with a 2-year-minimum follow-up. Spine 2001;36:230915. Spine (Phila Pa 1976). 2012;37(11):1014-1015; author reply 1016.

506. Wang MY. Metal-on-metal lumbar total disc arthroplasty: ready for prime time? World Neurosurg. 2012;78(34):247.

507. Wu JC, Tu TH, Mummaneni PV. Spinal arthroplasty: differences between the cervical and lumbar spine. World Neurosurg. 2012;78(3-4):245-246.

508. Freeman BJ. The role of lumbar disc replacement in the surgical management of low back pain. Br J Hosp Med (Lond). 2012;73(1):38-43.

509. Gerometta A, Rodriguez Olaverri JC, Bittan F. Infection and revision strategies in total disc arthroplasty. Int Orthop. 2012;36(2):471-474.

510. Awe OO, Maltenfort MG, Prasad S, Harrop JS, Ratliff JK. Impact of total disc arthroplasty on the surgical management of lumbar degenerative disc disease: analysis of the Nationwide Inpatient Sample from 2000 to 2008. Surg Neruol Int. 2011;2:139.

511. Uschold TD, Fusco D, Germain R, Tumialan LM, Chang SW. Cervical and lumbar spinal arthroplasty: clinical review. AJNR Am J Neuroradio. 2012;33(9):1631-1641.

512. Mayer HM, Siepe CJ. Prosthetic total disk replacement-can we learn from total hip replacement? Orthop Clin North Am. 2011;42(4):543-554, viii.

513. Berg S. On total disc replacement. Acta Orthop. 2011;82:1-29.

514. Zeilstra D, Oosterhuis W. Anterior lumbar discectomy and disc replacement. Eur Spine J. 2011;20(6):991-992.

515. Schoenfeld AJ. Commentary on an article by Rick Delamarter, MD, et al.: "Prospective, randomized, multicenter Food and Drug Administration investigational device exemption study of the ProDisc-L total disc replacement compared with circumferential arthrodesis for the treatment of two-level degenerative lumbar disc disease. Results at twenty-four months". J Bone Joint Surg Am. 2011;93(8):e41.

516. Gill NW, Konitzer LN, Hoppes CW. Lumbar total disc replacement. J Orthop Sports Phys Ther. 2011;41(3):200.

517. Bucciero A. Nubac disc arthroplasty via the posterior approach. Technical note. J Neurosurg Sci. 2010;54(2):83-89.

518. Serhan H, Mhatre D, Defossez H, Bono CM. Motionpreserving technologies for degenerative lumbar spine: The past, present, and future horizons. SAS J. 2011;5(3):75-89.

519. Blondel B, Tropiano P, Gaudart J, Marnay T. Clinical results of total lumbar disc replacement regarding various aetiologies of the disc degeneration: a study with a 2-year 
minimal follow-up. Spine (Phila Pa 1976). 2011;36(5):E313E319.

520. Wiechert K. [Keel-implants: Activ-L]. Oper Orthop Traumatol. 2010;22(5-6):608-619.

521. Hanley EN Jr, Herkowitz HN, Kirkpatrick JS, Wang JC, Chen MN, Kang JD. Debating the value of spine surgery. $J$ Bone Joint Surg Am. 2010;92(5):1293-1304.

522. Tropiano P. Expert's comment concerning Grand Rounds case entitled "Revision of a lumbar disc arthroplasty following late infection" (by Jeffrey M. Spivak and Anthony M. Petrizzo). Eur Spine J. 2010;19(5):682-684.

523. Rasmussen $\mathrm{S}$, Jensen $\mathrm{CM}$, Iversen $\mathrm{MG}$, Kehlet $\mathrm{H}$. [Lumbar fusion surgery for degenerative conditions in Denmark 2005-2006]. Ugeskr Laeger. 2009;171(39):2804-2807.

524. Bono CM. Hybrids: good for cars and the environment-are they good for the spine too? Spine J. 2009;9(10):857858 .

525. Madigan L, Vaccaro AR, Spector LR, Milam RA. Management of symptomatic lumbar degenerative disk disease. J Am Acad Orthop Surg. 2009;17(2):102-111.

526. Garcia RM, Messerschmitt PJ, Ahn NU. An evaluation of information on the Internet of a new device: the lumbar artificial disc replacement. $J$ Spinal Discord Tech. 2009;22(1):52-57.

527. Whang PG, Simpson AK, Rechtine G, Grauer JN. Current trends in spinal arthroplasty: an assessment of surgeon practices and attitudes regarding cervical and lumbar disk replacement. J Spinal Discord Tech. 2009;22(1):26-33.

528. Wright TM. CORR Insights(R): Periprosthetic UHMWPE wear debris induces inflammation, vascularization, and innervation after total disc replacement in the lumbar spine. Clin Orthop Relat Res. 2017;475(5):1369-1381.

529. Ding F, Jia Z, Zhao Z, et al. Total disc replacement versus fusion for lumbar degenerative disc disease: a systematic review of overlapping meta-analyses. Eur Spine J. 2017;26(3):806-815.

530. Yue JJ, Garcia R Jr, Miller LE. The activL( $\left.{ }^{\circledR}\right)$ Artificial disc: a next-generation motion-preserving implant for chronic lumbar discogenic pain. Med Devices (Auckl). 2016;9:75-84.

531. Krieg SM, Meyer HS, Meyer B. [Spinal column: implants and revisions]. Chirurg. 2016;87(3):202-207.

532. Malakoutian M, Volkheimer D, Street J, Dvorak MF, Wilke HJ, Oxland TR. Do in vivo kinematic studies provide insight into adjacent segment degeneration? A qualitative systematic literature review. Eur Spine J. 2015;24(9):1865-1881.

533. Buttner-Janz K, Guyer RD, Ohnmeiss DD. Indications for lumbar total disc replacement: selecting the right patient with the right indication for the right total disc. Int $J$ Spine Surg. 2014;8.

534. Jaumard NV, Welch WC, Winkelstein BA. Spinal facet joint biomechanics and mechanotransduction in normal, injury and degenerative conditions. $J$ Biomech Eng. 2011;133(7):071010.

535. Charles YP, Walter A, Schuller S, Steib JP. [Dynamic instrumentation of the lumbar spine. Clinical and biomechanical analysis of success factors]. Orthopade. 2011;40(8):703-712.

536. Cheng WK, Jadhav V, Palmer DK. A novel modification for removal of the polyethylene core in artificial disc retrieval using a transpsoas minimally invasive technique. $J$ Neurosurg Spine. 2011;14(4):466-469.
537. Zarghooni K, Siewe J, Eysel P. [State of the art of lumbar intervertebral disc replacement]. Orthopade. 2011;40(2):141-147.

538. Cheng WK, Palmer DK. Response to editorial regarding a novel surgical treatment option in which posterior dynamic stabilization is used to correct coronal plane tilt of a lumbar total disc replacement. SAS J. 2011;5(4):131.

539. Araghi A, Ferrara L. Letter to the editor: Novel indication for posterior dynamic stabilization: correction of disc tilt after lumbar total disc replacement. SAS J. 2011;5(3):95.

540. Huang YJ, Qian SJ, Zhang N, Chen WS. [Clinical application and advancement of artificial intervertebral discs for lumbar degenerative disease]. Zhongguo Gu Shang. 2010;23(10):797-800.

541. Pearcy MJ. Artificial lumbar intervertebral disc replacement: accepted practice or experimental surgery? Expert Rev Med Devices. 2010;7(6):855-860.

542. Schizas C, Kulik G, Kosmopoulos V. Disc degeneration: current surgical options. Eur Cell Mater. 2011;20:306315 .

543. Leivseth G, Brinckmann P. Re: Siepe CJ, Hitzl W, Meschede $\mathrm{P}$, et al. Interdependence between disc space height, range of motion and clinical outcome in total lumbar disc replacement. Spine (Phila Pa 1976).2009;34:904-16. Spine (Phila Pa 1976). 2010;35(17):1660; author reply 1660-1661.

544. van den Eerenbeemt KD, Ostelo RW, van Royen BJ, Peul WC, van Tulder MW. Total disc replacement surgery for symptomatic degenerative lumbar disc disease: a systematic review of the literature. Eur Spine J. 2010;19(8):1262-1280.

545. Kishen TJ, Diwan AD. Fusion versus disk replacement for degenerative conditions of the lumbar and cervical spine: quid est testimonium? Orthop Clin North Am. 2010;41(2):167-181.

546. Yajun W, Yue Z, Xiuxin H, Cui C. A meta-analysis of artificial total disc replacement versus fusion for lumbar degenerative disc disease. Eur Spine J. 2010;19(8):1250-1261.

547. Guyer RD. Re: "prospective, randomized multicenter Food and Drug Administration investigational device exemption study of lumbar tool disc replacement with the CHARITE artificial disc versus lumbar fusion: five-year follow-up". Spine $J$. 2010;10(4):360; author reply 361-363.

548. Schwarzenbach O. Hybrid stabilization with ALIF L5/S1 and total disc replacement L4/L5. Eur Spine J. 2009;18(12):1995-1996.

549. Chou R, Baisden J, Carragee EJ, Resnick DK, Shaffer WO, Loeser JD. Surgery for low back pain: a review of the evidence for an American Pain Society Clinical Practice Guideline. Spine (Phila Pa 1976). 2009;34(10):1094-1109.

550. Grob D. [Lumbar total disc replacement]. Orthopade. 2009;38(1):93-99; quiz 100-101.

551. Quirno M, Goldstein JA, Bendo JA, Kim Y, Spivak JM. The incidence of potential candidates for total disc replacement among lumbar and cervical fusion patient populations. Asian Spine J. 2011;5(4):213-219.

552. Murtagh RD, Quencer RM, Cohen DS, Yue JJ, Sklar EL. Normal and abnormal imaging findings in lumbar total disk replacement: devices and complications. Radiographics. 2009;29(1):105-118.

553. Jacobs WC, van der Gaag NA, Kruyt MC, et al. Total disc replacement for chronic discogenic low back pain: a Cochrane review. Spine (Phila Pa 1976). 2013;38(1):24-36. 
554. Nalley C, Castellvi A, Abitbol J.-J. Current status of lumbar disc replacements and motion preservation devices. Curr Orthop Pract. 2014;25(1):4-8.

555. Park CK. Lumbar total disc replacement: does it still need further follow-up? J Spine Surg. 2017;3(3):460-462.

556. Salzmann SN, Plais N, Shue J, Girardi FP. Lumbar disc replacement surgery-successes and obstacles to widespread adoption. Curr Rev Musculoskelet Med. 2017;10(2):153-159.

557. Shein D, Shue J, Girardi F. Evaluation of Aesculap Implant Systems activl Artificial Disc for the treatment of degenerative disc disease. Expert Rev Med Devices. 13(12):1069-1072.

558. Wright TM. CORR Insights ${ }^{\circledR}$ : periprosthetic UHMWPE wear debris induces inflammation, vascularization, and innervation after total disc replacement in the lumbar spine. Clin Orthop Relat Res. 2017;475(5):1382-1385.

559. Jong-Il C, Dong-Jun L, Sung-Kon H, Sang-Dae K, Se-Hoon K. Biomechanical changes in disc pressure and facet strain after lumbar spinal arthroplasty with charite in the human cadaveric spine under physiologic compressive follower preload. Turk Neurosurg. 2016;27(2):252-258.

560. Siskey R, Peck J, Mehta H, Kosydar A, Kurtz S, Hill G. Development of a clinically relevant impingement test method for a mobile bearing lumbar total disc replacement. Spine J. 2016;16(9):1133-1142.

561. Shankar S, Kesavan D. Wear in ceramic on ceramic type lumbar total disc replacement: effect of radial clearance. Biomed Mater Eng. 2015;26(1-2):89-96.

562. Mroz A, Skalski K, Walczyk W. New lumbar disc endoprosthesis applied to the patient's anatomic features. Acta Bioeng Biomech. 2015;17(2):25-34.

563. Dreischarf $M$, Schmidt $H$, Putzier $M$, Zander $T$. Biomechanics of the L5-S1 motion segment after total disc replacement - Influence of iatrogenic distraction, implant positioning and preoperative disc height on the range of motion and loading of facet joints. J Biomech. 2015;48(12):3283-3291.

564. Mikhael M, Brooks JT, Akpolat YT, Cheng WK. Rotation effect and anatomic landmark accuracy for midline placement of lumbar artificial disc under fluoroscopy. Eur Spine J. 2017;26(3):794-798.

565. Moghadas P, Mahomed A, Shepherd DE, Hukins DW. Wear of the Charite ${ }^{\circledR}$ lumbar intervertebral disc replacement investigated using an electro-mechanical spine simulator. Proc Inst Mech Eng H. 2015;229(3):264-268.

566. Nayak AN, Doarn MC, Gaskins RB, 3rd, et al. Postero-lateral disc prosthesis combined with a unilateral facet replacement device maintains quantity and quality of motion at a single lumbar level. Int J Spine Surg. 2014;8.

567. van Uden S, Silva-Correia J, Correlo VM, Oliveira JM, Reis RL. Custom-tailored tissue engineered polycaprolactone scaffolds for total disc replacement. Biofabrication. 2015;7(1):015008.

568. Hyde PJ, Tipper J, Fisher J, Hall RM. Wear and biological effects of a semi-constrained total disc replacement subject to modified ISO standard test conditions. $J$ Mech Behav Biomed Mater. 2015;44:43-52.

569. Pimenta L, Turner A, Oliveira L, Marchi L, Cornwall B. Controlled motion with the XL-TDR lateral-approach lumbar total disk replacement: in vitro kinematic investigation. J Neurol Surg A Cent Eur Neurosurg. 2015;76(2):133-138.

570. Yao Q, Wang JC, Shamie AN, et al. The effects of a semiconstrained integrated artificial disc on zygapophyseal joint pressure and displacement. Spine (Phila Pa 1976). 2014;39(25):E1510-E1517.

571. Rohlmann A, Lauterborn S, Dreischarf M, et al. Parameters influencing the outcome after total disc replacement at the lumbosacral junction. Part 1: misalignment of the vertebrae adjacent to a total disc replacement affects the facet joint and facet capsule forces in a probabilistic finite element analysis. Eur Spine J. 2013;22(10):2271-2278.

572. Baxter RM, Macdonald DW, Kurtz SM, Steinbeck MJ. Severe impingement of lumbar disc replacements increases the functional biological activity of polyethylene wear debris. $J$ Bone Joint Surg Am. 2013;95(11):e751-e759.

573. Han KS, Kim K, Park WM, Lim DS, Kim YH. Effect of centers of rotation on spinal loads and muscle forces in total disk replacement of lumbar spine. Proc Inst Mech Eng $H$. 2013;227(5):543-550.

574. Punt I, van Rijsbergen M, van Rietbergen B, et al. Subsidence of SB Charite total disc replacement and the role of undersizing. Eur Spine J. 2013;22(10):2264-2270.

575. Kurtz SM, Toth JM, Siskey R, et al. The latest lessons learned from retrieval analyses of ultra-high molecular weight polyethylene, metal-on-metal, and alternative bearing total disc replacements. Semin Spine Surg. 2012;24(1):57-70.

576. Daniels AH, Paller DJ, Koruprolu S, McDonnell M, Palumbo MA, Crisco JJ. Dynamic biomechanical examination of the lumbar spine with implanted total disc replacement using a pendulum testing system. Spine (Phila Pa 1976). 2012;37(23):E1438-E1443.

577. Wei HW, Chiang YF, Chen YW, Cheng CK, Tsuang YH. The effects of different articulate curvature of artificial disc on loading distribution. $J$ Appl Biomater Funct Mater. 2012;10(2):107-112.

578. Wang W, Zhang H, Sadeghipour K, Baran G. Effect of posterolateral disc replacement on kinematics and stress distribution in the lumbar spine: a finite element study. Med Eng Phys. 2013;35(3):357-364.

579. Borkowski P, Marek P, Krzesinski G, et al. Finite element analysis of artificial disc with an elastomeric core in the lumbar spine. Acta Bioeng Biomech. 2012;14(1):59-66.

580. Zhu Q, Itshayek E, Jones CF, et al. Kinematic evaluation of one- and two-level Maverick lumbar total disc replacement caudal to a long thoracolumbar spinal fusion. Eur Spine J. 2012;21(Suppl 5):S599-S611.

581. Tsitsopoulos PP, Wojewnik B, Voronov LI, et al. Effect of prosthesis endplate lordosis angles on L5-S1 kinematics after disc arthroplasty. Eur Spine J. 2012;21(Suppl 5):S585-S591.

582. McNally D, Naylor J, Johnson S. An in vitro biomechanical comparison of Cadisc-L with natural lumbar discs in axial compression and sagittal flexion. Eur Spine J. 2012;21(Suppl 5):S612-S617.

583. Zhong ZC, Hung C, Lin HM, Wang YH, Huang CH, Chen CS. The influence of different magnitudes and methods of applying preload on fusion and disc replacement constructs in the lumbar spine: a finite element analysis. Comput Methods Biomech Biomed Engin. 2013;16(9):943-953.

584. Rundell SA, Day JS, Isaza J, Guillory S, Kurtz SM. Lumbar total disc replacement impingement sensitivity to disc height distraction, spinal sagittal orientation, implant position, 
and implant lordosis. Spine (Phila Pa 1976). 2012;37(10):E590E598.

585. Vicars R, Prokopovich P, Brown TD, et al. The effect of anterior-posterior shear on the wear of CHARITE total disc replacement. Spine (Phila Pa 1976). 2012;37(9):E528-E534.

586. Chen WC, Liu YL, Lin KJ, et al. Concave polyethylene component improves biomechanical performance in lumbar total disc replacement-modified compressive-shearing test by finite element analysis. Med Eng Phys. 2012;34(4):498505 .

587. Gao SG, Lei $\mathrm{GH}, \mathrm{He} \mathrm{HB}$, et al. Biomechanical comparison of lumbar total disc arthroplasty, discectomy, and fusion: effect on adjacent-level disc pressure and facet joint force. J Neurosurg Spine. 2011;15(5):507-514.

588. Punt I, Baxter R, van Ooij A, Willems P, van Rhijn L, Kurtz S, Steinbeck M. Submicron sized ultra-high molecular weight polyethylene wear particle analysis from revised SB Charite III total disc replacements. Acta Biomater. 2011;7(9):3404-3411.

589. Brown T, Bao QB, Agrawal CM, Hallab NJ. An in vitro assessment of wear particulate generated from NUBAC: a PEEK-on-PEEK articulating nucleus replacement device: methodology and results from a series of wear tests using different motion profiles, test frequencies, and environmental conditions. Spine (Phila Pa 1976). 2011;36(26):E1675-E1685.

590. Knapik GG, Mendel E, Marras WS. Use of a personalized hybrid biomechanical model to assess change in lumbar spine function with a TDR compared to an intact spine. Eur Spine J. 2012;21(Suppl 5):S641-S652.

591. Bowles RD, Gebhard HH, Dyke JP, et al. Imagebased tissue engineering of a total intervertebral disc implant for restoration of function to the rat lumbar spine. $N M R$ Biomed. 2012;25(3):443-451.

592. Noailly J, Ambrosio L, Elizabeth Tanner K, Planell JA, Lacroix D. In silico evaluation of a new composite disc substitute with a L3-L5 lumbar spine finite element model. Eur Spine J. 2012;21(Suppl 5):S675-S687.

593. Rundell SA, Isaza JE, Kurtz SM. Biomechanical evaluation of a spherical lumbar interbody device at varying levels of subsidence. SAS J. 2011;5(1):16-25.

594. Kettler A, Bushelow M, Wilke HJ. Influence of the loading frequency on the wear rate of a polyethylene-on-metal lumbar intervertebral disc replacement. Eur Spine J. 2012;21(Suppl 5):S709-S716.

595. Wilke HJ, Schmidt R, Richter M, Schmoelz W, Reichel H, Cakir B. The role of prosthesis design on segmental biomechanics: semi-constrained versus unconstrained prostheses and anterior versus posterior centre of rotation. Eur Spine J. 2012;21(Suppl 5):S577-S584.

596. Gaffey JL, Ghanayem AJ, Voronov ML, et al. Effect of increasing implant height on lumbar spine kinematics and foraminal size using the ProDisc-L prosthesis. Spine (Phila Pa 1976). 2012;35(19):1777-1782.

597. Goreham-Voss CM, Vicars R, Hall RM, Brown TD. Preferential superior surface motion in wear simulations of the Charite total disc replacement. Eur Spine J. 2012;21(Suppl 5):S700-S708.

598. Brown T, Bao QB, Kilpela T, Songer M. An in vitro biotribological assessment of NUBAC, a polyetheretherketoneon-polyetheretherketone articulating nucleus replacement device: methodology and results from a series of wear tests using different motion profiles, test frequencies, and environmental conditions. Spine (Phila Pa 1976). 2010;35(16):E774-E781.

599. Kikkawa J, Cunningham BW, Shirado O, Hu N, McAfee PC, Oda H. Biomechanical evaluation of a posterolateral lumbar disc arthroplasty device: an in vitro human cadaveric model. Spine (Phila Pa 1976). 2010;35(19):17601768 .

600. Yoder JH, Auerbach JD, Maurer PM, et al. Augmentation improves human cadaveric vertebral body compression mechanics for lumbar total disc replacement. Spine (Phila Pa 1976). 2010;35(9):E325-E331.

601. Schmidt H, Galbusera F, Rohlmann A, Zander T, Wilke HJ. Effect of multilevel lumbar disc arthroplasty on spine kinematics and facet joint loads in flexion and extension: a finite element analysis. Eur Spine J. 2012;21(Suppl 5):S663-S674.

602. Kafchitsas K, Kokkinakis M, Habermann B, Rauschmann M. Effect of lumbar disc replacement on the height of the disc space and the geometry of the facet joints: a cadaver study. J Bone Joint Surg Br. 2010;92(4):595-601.

603. Weisskopf M, Maus U, Ohnsorge JA, Prescher A, Pandorf T, Birnbaum K. [Influence of disc prosthesis position on segmental motion in the lumbar spine]. Z Orthop Unfall. 2010;148(4):453-458.

604. Marshman LA, Strong G, Trewhella M, Kasis A, Friesem T. Minimizing ferromagnetic artefact with metallic lumbar total disc arthroplasty devices at adjacent segments: technical note. Spine (Phila Pa 1976). 2010;35(2):252-256.

605. Le Huec JC, Lafage V, Bonnet X, et al. Validated finite element analysis of the maverick total disc prosthesis. $J$ Spinal Discord Tech. 2010;23(4):249-257.

606. Demetropoulos CK, Sengupta DK, Knaub MA, et al. Biomechanical evaluation of the kinematics of the cadaver lumbar spine following disc replacement with the ProDisc-L prosthesis. Spine (Phila Pa 1976). 2010;35(1):26-31.

607. Ingalhalikar AV, Reddy CG, Lim TH, Torner JC, Hitchon PW. Effect of lumbar total disc arthroplasty on the segmental motion and intradiscal pressure at the adjacent level: an in vitro biomechanical study: presented at the 2008 Joint Spine Section Meeting Laboratory investigation. J Neurosurg Spine. 2009;11(6):715-723.

608. Shikinami Y, Kawabe Y, Yasukawa K, Tsuta K, Kotani Y, Abumi K. A biomimetic artificial intervertebral disc system composed of a cubic three-dimensional fabric. Spine $J$. 2010;10(2):141-152.

609. Cakir B, Richter M, Schmoelz W, Schmidt R, Reichel H, Wilke HJ. Resect or not to resect: the role of posterior longitudinal ligament in lumbar total disc replacement. Eur Spine J. 2012;21(Suppl 5):S592-S598.

610. Kurtz SM, MacDonald D, Ianuzzi A, et al. The natural history of polyethylene oxidation in total disc replacement. Spine (Phila Pa 1976). 2009;34(22):2369-2377.

611. Schmidt H, Midderhoff S, Adkins K, Wilke HJ. The effect of different design concepts in lumbar total disc arthroplasty on the range of motion, facet joint forces and instantaneous center of rotation of a L4-5 segment. Eur Spine J. 2009;18(11):1695-1705.

612. Kim SH, Chang UK, Chang JC, Chun KS, Lim TJ, $\mathrm{Kim} \mathrm{DH}$. The changes in range of motion after a lumbar spinal arthroplasty with charite in the human cadaveric spine under physiologic compressive follower preload : a comparative study 
between load control protocol and hybrid protocol. $J$ Korean Neurosurg Soc. 2009;46(2):144-151.

613. Cunningham BW, Hu N, Zorn CM, McAfee PC. Bioactive titanium calcium phosphate coating for disc arthroplasty: analysis of 58 vertebral end plates after 6- to 12-month implantation. Spine J. 2009;9(10):836-845.

614. Cunningham BW, Hu N, Beatson HJ, Serhan H, Sefter JC, McAfee PC. Revision strategies for single- and twolevel total disc arthroplasty procedures: a biomechanical perspective. Spine J. 2009;9(9):735-743.

615. Erkan S, Rivera Y, Wu C, Mehbod AA, Transfeldt EE. Biomechanical comparison of a two-level Maverick disc replacement with a hybrid one-level disc replacement and onelevel anterior lumbar interbody fusion. Spine J. 2009;9(10):830835.

616. Rauschmann MA, Thalgott J, Fogarty M, et al. Insertion of the artificial disc replacement: a cadaver study comparing the conventional surgical technique and the use of a navigation system. Spine (Phila Pa 1976). 2009;34(10):11101115 .

617. Cunningham BW, Berven SH, Hu N, Beatson HJ, De Deyne PG, McAfee PC. Regeneration of a spinal ligament after total lumbar disk arthroplasty in primates. Cells Tissues Organs. 2009; 190(6):347-355.

618. Ha SK, Kim SH, Kim DH, Park JY, Lim DJ, Lee SK. Biomechanical study of lumbar spinal arthroplasty with a semiconstrained artificial disc (activ L) in the human cadaveric spine. J Korean Neurosurg Soc. 2009;45(3):169-175.

619. Pare PE, Chan FW, Bhattacharya S, Goel VK. Surface slide track mapping of implants for total disc arthroplasty. J Biomech. 2009;42(2):131-139.

620. Zander T, Rohlmann A, Bergmann G. Influence of different artificial disc kinematics on spine biomechanics. Clin Biomech (Bristol, Avon). 2009;24(2):135-142.

621. Grupp TM, Yue JJ, Garcia R Jr, et al. Biotribological evaluation of artificial disc arthroplasty devices: influence of loading and kinematic patterns during in vitro wear simulation. Eur Spine J. 2009;18(1):98-108.

622. Rohlmann A, Mann A, Zander T, Bergmann G. Effect of an artificial disc on lumbar spine biomechanics: a probabilistic finite element study. Eur Spine J. 2009;18(1):8997.

623. Chen SH, Zhong ZC, Chen CS, Chen WJ, Hung C. Biomechanical comparison between lumbar disc arthroplasty and fusion. Med Eng Phys. 2009;31(2):244-253.

624. Choi J, Shin DA, Kim S. Biomechanical effects of the geometry of ball-and-socket artificial disc on lumbar spine: a finite element study. Spine (Phila Pa 1976). 2017;42(6):E332E339.

625. Hyde PJ, Fisher J, Hall RM. Wear simulation of a polyethylene-on-metal cervical total disc replacement under different concentrations of bovine serum lubricant. Proc Inst Mech Eng H. 2016;230(5):481-488.

626. Holsgrove TP, Gill HS, Miles AW, Gheduzzi S. Dynamic, six-axis stiffness matrix characteristics of the intact intervertebral disc and a disc replacement. Proc Inst Mech Eng H. 2015;229(11):769-777.

627. Hyde PJ, Fisher J, Hall RM. Wear characteristics of an unconstrained lumbar total disc replacement under a range of in vitro test conditions. J Biomed Mater Res B Appl Biomater. 2017;105(1):46-52.
628. Volkheimer D, Malakoutian M, Oxland TR, Wilke HJ. Limitations of current in vitro test protocols for investigation of instrumented adjacent segment biomechanics: critical analysis of the literature. Eur Spine J. 2015;24(9):1882-1892.

629. Canadian Agency for Drugs and Technologies in Health. Compressible Non-Articulating Disc Prosthesis in Adult Patients With Degenerative Disc Disease: Clinical Effectiveness, Safety, Cost-Effectiveness, and Guidelines. Ottawa, ON, Canada: CADTH; 2014.

630. Shahmohammadi M, Asgharzadeh Shirazi H, Karimi A, Navidbakhsh M. Finite element simulation of an artificial intervertebral disk using fiber reinforced laminated composite model. Tissue Cell. 2014;46(5):299-303.

631. Halverson PA, Bowden AE, Howell LL. A compliantmechanism approach to achieving specific quality of motion in a lumbar total disc replacement. Int J Spine Surg. 2012;6:78-86.

632. Prokopovich P, Perni S, Fisher J, Hall RM. Spatial variation of wear on Charite lumbar discs. Acta Biomater. 2011;7(11):3914-3926.

633. Costi JJ, Freeman BJ, Elliott DM. Intervertebral disc properties: challenges for biodevices. Expert Rev Med Devices. 2011;8(3):357-376.

634. Botolin S, Puttlitz C, Baldini T, et al. Facet joint biomechanics at the treated and adjacent levels after total disc replacement. Spine (Phila Pa 1976). 2011;36(1):E27-E32.

635. Takigawa T, Espinoza Orias AA, An HS, et al. Spinal kinematics and facet load transmission after total disc replacement. Spine (Phila Pa 1976). 2010;35(22):E1160-E1166.

636. Di Mascio V, Bellini CM, Galbusera F, Raimondi MT, Brayda-Bruno M, Assietti R. Lumbar total disc replacement: a numerical study. $J$ Apple Biomater Biomed. 2010;8(2):97-101.

637. Kim KT, Lee SH, Suk KS, Lee JH, Jeong BO. Biomechanical changes of the lumbar segment after total disc replacement : charite(r), prodisc(r) and maverick(r) using finite element model study. J Korean Neurosurg Soc. 2010;47(6):446453.

638. Auerbach JD, Ballester CM, Hammond F, Carine ET, Balderston RA, Elliott DM. The effect of implant size and device keel on vertebral compression properties in lumbar total disc replacement. Spine J. 2010;10(4):333-340.

639. Chen WM, Park C, Lee K, Lee S. In situ contact analysis of the prosthesis components of Prodisc-L in lumbar spine following total disc replacement. Spine (Phila Pa 1976). 2009;34(20):E716-E723.

640. Quirno M, Kamerlink JR, Valdevit A, et al. Biomechanical analysis of a disc prosthesis distal to a scoliosis model. Spine (Phila Pa 1976). 2009;34(14):1470-1475.

641. Chung SK, Kim YE, Wang KC. Biomechanical effect of constraint in lumbar total disc replacement: a study with finite element analysis. Spine (Phila Pa 1976). 2009;34(12):1281-1286.

642. Ge L, Li K, Hu J, Lei G. [Effect of lumbar discectomy and disc replacement on compressive load in proximal adjacent segment]. Zhong Nan Da Xие Xие Bao Yi Xие Ban. 2009;34(3):230-235.

643. Moldavsky M, Neumann P, Klocke N, Hussain M, Bucklen BS. In vitro analysis of circumferential joint replacement, including bilateral facet joint replacement with lateral lumber disc prosthesis: a parametric investigation of disc sizing. Eur Spine J. 2017;26(3):785-793. 
644. Mahomed A, Moghadas PM, Shepherd DE, Hukins DW, Roome A, Johnson S. Effect of axial load on the flexural properties of an elastomeric total disc replacement. Spine (Phila Pa 1976). 2012;37(15):E908-E912.

645. Gwynne JH, Cameron RE. Using small angle X-ray scattering to investigate the variation in composition across a graduated region within an intervertebral disc prosthesis. $J$ Mater Sci Mater Med. 2010;21(2):787-795.

646. Vicars R, Hyde PJ, Brown TD, et al. The effect of anterior-posterior shear load on the wear of ProDisc-L TDR. Eur Spine J. 2010;19(8):1356-1362.

647. Goreham-Voss CM, Hyde PJ, Hall RM, Fisher J, Brown TD. Cross-shear implementation in sliding-distancecoupled finite element analysis of wear in metal-on-polyethylene total joint arthroplasty: intervertebral total disc replacement as an illustrative application. J Biomech. 2010;43(9):16741681 .

648. Reeks J, Liang H. Materials and their failure mechanisms in total disc replacement. Lubricants. 2015;3:346.

649. Hallab NJ. A review of the biologic effects of spine implant debris: fact from fiction. SAS J. 2009;3(4):143-160.

650. Yue JJ, Mo FF. Clinical study to evaluate the safety and effectiveness of the Aesculap Activ-L artificial disc in the treatment of degenerative disc disease. BMC Surg. 2010;10:14.

651. Howick J, Glasziou P, Aronson JK. Evidence-based mechanistic reasoning. $J$ R Soc Med. 2010;103(11):433-441.

652. Brox JI, Sorensen R, Friis A, et al. Randomized clinical trial of lumbar instrumented fusion and cognitive intervention and exercises in patients with chronic low back pain and disc degeneration. Spine (Phila Pa 1976). 2003;28(17):1913-1921.

653. Gellhorn AC, Katz JN, Suri P. Osteoarthritis of the spine: the facet joints. Nat Rev Rheumatol. 2013;9(4):216-224.

654. Dunlop RB, Adams MA, Hutton WC. Disc space narrowing and the lumbar facet joints. $J$ Bone Joint Surg $\mathrm{Br}$. 1984;66(5):706-710.

655. Adams MA, Hutton WC. The mechanical function of the lumbar apophyseal joints. Spine (Phila Pa 1976). 1983;8(3):327-330.

656. Brailsford JF. Deformities of the lumbosacral region of the spine. Br J Surg. 1929;16(64):562-627.

657. Zeng ZL, Jia L, Xu W, et al. Analysis of risk factors for adjacent superior vertebral pedicle-induced facet joint violation during the minimally invasive surgery transforaminal lumbar interbody fusion: a retrospective study. Eur J Med Res. 2015;20:80.

658. Trummer M, Eustacchio S, Barth M, Klassen PD, Stein S. Protecting facet joints post-lumbar discectomy: Barricaid annular closure device reduces risk of facet degeneration. Clin Neurol Neurosurg. 2013;115(8):1440-1445.

659. Steib K, Proescholdt M, Brawanski A, Lange M, Schlaier J, Schebesch KM. Predictors of facet joint syndrome after lumbar disc surgery. J Clin Neurosci. 2012;19(3):L418422.

660. Veruva SY, Lanman TH, Hanzlik JA, Kurtz SM, Steinbeck MJ. Rare complications of osteolysis and periprosthetic tissue reactions after hybrid and non-hybrid total disc replacement. Eur Spine J. 2015;24(Suppl 4);S494-S501.

661. Saleh KJ, Thongtrangan I, Schwarz EM. Osteolysis: medical and surgical approaches. Clin Orthop Relat Res. 2004;(427):138-147.

662. Veruva SY, Steinbeck MJ, Toth J, Alexander DD, Kurtz SM. Which design and biomaterial factors affect clinical wear performance of total disc replacements? A systematic review. Clin Orthop Relat Res. 2014;472(12):3759-3769.

663. Pinheiro MB, Ferreira ML, Refshauge K, et al. Symptoms of depression as a prognostic factor for low back pain: a systematic review. Spine J. 2016;16(1):105-116.

664. Basler HD. [Chronification process of backache]. Ther Umsch. 1994;51(6):395-402.

665. Cancelliere C, Donovan J, Stochkendahl MJ, et al. Factors affecting return to work after injury or illness: best evidence synthesis of systematic reviews. Chiropr Man Therap. 2016;24(1):32.

666. Ghiselli G, Wang JC, Bhatia NN, Hsu WK, Dawson EG. Adjacent segment degeneration in the lumbar spine. $J$ Bone Joint Surg Am. 2004;86-A(7):1497-1503.

667. Olsewski JM, Schendel MJ, Wallace LJ, Ogilvie JW, Gundry CR. Magnetic resonance imaging and biological changes in injured intervertebral discs under normal and increased mechanical demands. Spine (Phila Pa 1976). 1996;21(17):1945-1951.

668. Phillips FM, Reuben J, Wetzel FT. Intervertebral disc degeneration adjacent to a lumbar fusion. An experimental rabbit model. J Bone Joint Surg Br. 2002;84(2):289-294.

669. Shono Y, Kaneda K, Abumi K, McAfee PC, Cunningham BW. Stability of posterior spinal instrumentation and its effects on adjacent motion segments in the lumbosacral spine. Spine (Phila Pa 1976). 1998;23(14):1550-1558.

670. Fritzell P, Knutsson B, Sanden B, Stromqvist B, Hagg O. Recurrent versus primary lumbar disc herniation surgery: patient-reported outcomes in the Swedish spine register swespine. Clin Orthop Relat Res. 2015;473(6):1978-1984.

671. Brox JI, Storheim K, Grotle M, Tveito TH, Indahl A, Eriksen HR. Systematic review of back schools, brief education, and fear-avoidance training for chronic low back pain. Spine $J$. 2008;8(6):948-958.

672. Campbell P, Wynne-Jones G, Muller S, Dunn KM. The influence of employment social support for risk and prognosis in nonspecific back pain: a systematic review and critical synthesis. Int Arch Occup Environ Health. 2013;86(2):119-137.

673. Carroll C, Rick J, Pilgrim H, Cameron J, Hillage J. Workplace involvement improves return to work rates among employees with back pain on long-term sick leave: a systematic review of the effectiveness and cost-effectiveness of interventions. Disabil Rehabil. 2010;32(8):607-621.

674. Kalakoti P, Missios S, Menger R, Kukreja S, Konar S, Nanda A. Association of risk factors with unfavorable outcomes after resection of adult benign intradural spine tumors and the effect of hospital volume on outcomes: an analysis of 18, 297 patients across 774 US hospitals using the National Inpatient Sample (2002-2011). Neurosurg Focus. 2015;39(2):E4

675. Menger RP, Wolf ME, Kukreja S, Sin A, Nanda A. Medicare payment data for spine reimbursement; important but flawed data for evaluating utilization of resources. Surg Neurol Int. 2015;6(Suppl 14):S391-S397.

676. Etzioni DA, Wasif N, Mathur AK, Habermann EB, Cima RR, Chang YH. Impact of unaccounted risk factors on 
the interpretation of surgical outcomes. $J$ Am Coll Surg. 2015;221(4):821-827.

677. Turner L. Canada's turbulent medical tourism industry. Can Fam Physician. 2012;58(4):371-373.

678. Jiang J, Ren ZH, Lu HS. [Primary study of relationship between lumbar degenerative disease and morbidity of primary knee osteoarthritis]. Zhonghua Yi Xue Za Zhi 2010;90(7):466-468.

679. Andrade NS, Flynn JP, Bartanusz V. Twenty-year perspective of randomized controlled trials for surgery of chronic nonspecific low back pain: citation bias and tangential knowledge. Spine J. 2013;13(11):1698-1704.

680. Feld AD. Informed consent: not just for procedures anymore. Am J Gastroenterol. 2004;99(6):977-980.

681. Bardes CL. Defining "patient-centered medicine". $N$ Engl J Med. 2012;366(9):782-783.

682. Barry MJ, Edgman-Levitan S. Shared decision making-pinnacle of patient-centered care. $N$ Engl $J$ Med. 2012;366(9):780-781.

683. Weckbach S, Kocak T, Reichel H, Lattig F. A survey on patients' knowledge and expectations during informed consent for spinal surgery: can we improve the shared decision-making process? Patient Saf Surg. 2016;10:15.

684. Robertson L. Contemporary interpretation of in- formed consent: autonomy and paternalism. $\mathrm{Br} J$ Hosp Med (Lond). 2016;77(6):358-361.

685. Brezis M, Israel S, Weinstein-Birenshtock A, Pogoda P, Sharon A, Tauber R. Quality of informed consent for invasive procedures. Int J Qual Health Care. 2008;20(5):352357.

686. Ossipov MH, Morimura K, Porreca F. Descending pain modulation and chronification of pain. Curr Opin Support Palliat Care. 2014;8(2):143-151.

Corresponding Author: Stephen Beatty, Institute of Health Sciences, NRCI, Carriganore House, West Campus Carriganore, Waterford Institute of Technology, Waterford, Republic of Ireland. Phone: 353-51-834074; Email: stephen@ivr. ie.

Published 3 August 2018

This manuscript is generously published free of charge by ISASS, the International Society for the Advancement of Spine Surgery. Copyright (c) 2018 ISASS. To see more or order reprints or permissions, see http://ijssurgery.com. 